\title{
Seismic Qualification of PWR Plant Auxiliary Feedwater Systems
}

\section{DISCLAIMER}

\begin{abstract}
This report was prepared as an account of work sponsored by an aseacy of the United States Government. Neither the United States Goveroment nor any agency thereof, nor any of their employees, makes any warnenty, express or implied, or surumes any legal linbility or responsibility for the accuracy, completeness, or usefuloess of any information, apparatus, product, or process disclosed, or represents that its use would not infringe privately owsed riphts. Reference herein to any specific commercial product, process, or service by trade anme, trademark, manufacturer, or otherwise does not neceasarily constitute or imply its endorsement, recommendation, or favoring by the United States Government or any agency thereof. The views and opinions of authors expressed berein do not necessarily state or reflect those of the Uaited States Govemment or any agency thereof.
\end{abstract}

Manuscript Completed: August 1983

Date Published:

Prepared by

S. C. Lu

Lawrence Livermore National Laboratory

N. C. Tsai,

N.C.T. Engineering, Inc.

Lawrence Livermore National Laboratory

7000 East Averitue

Livermore, CA 94550

Prepared for

Division of Engineering Technology

Office of Regulatory Research

U.S. Nuclear Regulatory Commission

Washington, DC 20555

NRC FIN No. A0383

\section{MASTER}

\section{NOTICE}

PORTIOHS OF THIS REPORT ARE ILLEGIBLE.

it has been reproduced from the best available copy to permit the broadtes, possibte availability. 


\section{ABSTRACT}

The NRC Standard Review Plan specifies that the auxiliary feedwater (AFW) system of a preasurized water reactor (PWR) is a safeguard system that functiono in the event of a Safe Shutdown Earthquake (SSE) to remove the decay heat via the steam generator. Only recently licensed PWR plants have an AFW system designed to the current Standard Review Plan specifications. The NRC devised the Hultiplant Action Plan C-14 in order to make a survey of the seismic capability of the AFW systems of operating PWR plants. The purpose of this survey is to enable the NRC to make decisions regarding the need of requiring the licensees to upgrade the AFW systems to an SSE level of seismic capability. To implement the first phase of the C-14 plan, the NRC issued a Generic Letter (GL) 81-14 to all operating PWR licensees requesting information on the seismic capability of their AFW systems.

This report sumarizes Lawrence Livermore National Laboratory's efforts to assist the NRC in evaluating the status of seismic qualificatior of the AFW systems in 40 PWR plants, by reviewing the licensees' responses to GL 81-14. The result was the preparation of a Technical Evaluation Report (TER) for each plant. The TER identifies the status of seismic qualification and recoumends the need for reanalysis, possible upgrade, and modification of the AFW system. Each TER has been utilized as a technical basis for the NRC to issue a Safety Evaluation Report to each licensee involved in the review in order to implement the c-14 plan. Our technical evaluation indicated that, out of 40 plants, about $68 \%$ (27 plants) have a seismically qualified AFW system. Only about $7 \%$ ( 3 plantg) have major deficiencies in their AFW systems. In general, piping, valves/actuators, structures housing or supporting the AFW systems, and power supplies are the areas where deficiencies occurred most frequently. 
Abstract

Table of Contents

List of Tables

Acknowledgments

Executive Summary

Chapter

Page

1. Introduction $\ldots \ldots \ldots$

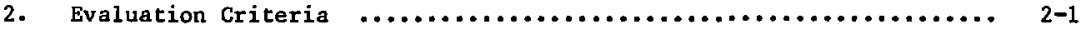

2.1 General Evaluation Criteria $. . \ldots \ldots \ldots \ldots \ldots \ldots \ldots \ldots \ldots \ldots \ldots \ldots \ldots . . . \ldots$ 2-1

2.1.1 Status of Seismic Qualification of AFW System Components. 2-2

2.1 .2 Boundary $\ldots \ldots \ldots \ldots \ldots \ldots \ldots \ldots \ldots \ldots \ldots \ldots \ldots \ldots \ldots \ldots \ldots \ldots \ldots . \ldots . \ldots \ldots$

2.1.3 Compliance of IE Bulletins and Information Notices ... 2-3

2.1 .4 Alternate Decay-heat Removal System ............... 2-4

2.1.5 Walkdown of Nonqualified AFW System Components ...... 2-4

2.2 Plant Specific Considerations $\ldots \ldots \ldots \ldots \ldots \ldots \ldots \ldots \ldots \ldots \ldots \ldots \ldots$

2.2 .1 Status of Seismic Qualification of AFW System ....... 2-5

2.2 .2 Boundary .................................. 2-6

2.2.3 Compliance of IE Bulletins and Information Notices ... 2-6

2.2.4 Walkdown of Nonqualified AFW System Areas .......... 2-7

3. Evaluation Results .................................... 3-1

3.1 Status of Overall Seismic Qualification ............... 3-8

3.2 Boundary $\ldots \ldots \ldots \ldots \ldots \ldots \ldots \ldots \ldots \ldots \ldots \ldots \ldots \ldots \ldots \ldots \ldots \ldots \ldots \ldots \ldots \ldots \ldots . . \ldots 3-9$

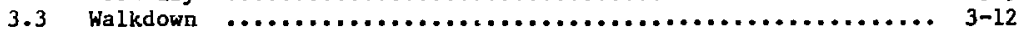

3.4 Alternate Decay-Heat Removal System .................. 3-12

3.5 Additional Information $\ldots \ldots \ldots \ldots \ldots \ldots \ldots \ldots \ldots \ldots \ldots \ldots \ldots \ldots \ldots \ldots . \ldots \ldots$

4. Conclusions and Recommendations $\ldots \ldots \ldots \ldots \ldots \ldots \ldots \ldots \ldots \ldots \ldots \ldots \ldots \ldots \ldots$ 4-1

5. References $\ldots \ldots \ldots \ldots \ldots \ldots \ldots \ldots \ldots \ldots \ldots \ldots \ldots \ldots \ldots \ldots \ldots \ldots \ldots \ldots \ldots \ldots \ldots \ldots \ldots, 5-1$

Appendix: Technical Evaluation Reports

Arkansas, Unit $1 \quad \ldots \ldots \ldots \ldots \ldots \ldots \ldots \ldots \ldots \ldots \ldots \ldots \ldots \ldots \ldots \ldots \ldots \ldots \ldots \ldots \ldots$ A-1

Arkansas, Unit 2 ..................................... A -5

Beaver Valley, Unit 1 ................................ A-8

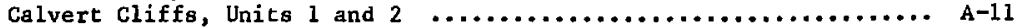

D.C. Cook, Units 1 and 2 .............................. A-17

Crystal River, Unit 3 ................................. A-22

Davis-Besse, Unit 1 ................................. A-27

Farley, Unite 1 and 2 .......................................

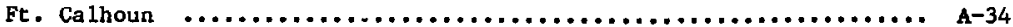

Indian Point, Unit 2 ................................ A-38 
Appendix: Technical Evaluation Reports (Cont'd)

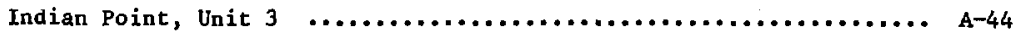

Kewanee $\ldots \ldots \ldots \ldots \ldots \ldots \ldots \ldots \ldots \ldots \ldots \ldots \ldots \ldots \ldots \ldots \ldots \ldots \ldots \ldots \ldots \ldots \ldots \ldots \ldots$ A $\ldots \ldots$

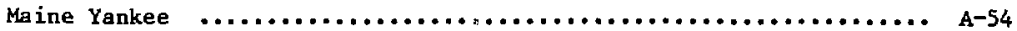

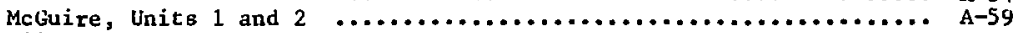

Millstone, Unit 2 ................................ A-62

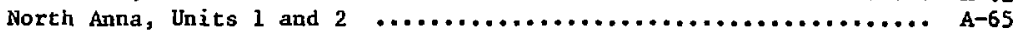

Oconee, Units, 1,2 , and $J$. ........................... A-68

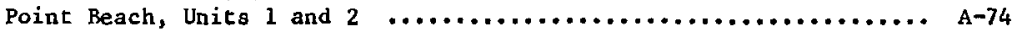

Prairie Island, Units 1 and $2 \ldots \ldots \ldots \ldots \ldots \ldots \ldots \ldots \ldots \ldots \ldots \ldots \ldots \ldots$

Rancho Seco, Unit 1 .................................. A-85

H. B. Robinson ....................................... A-89

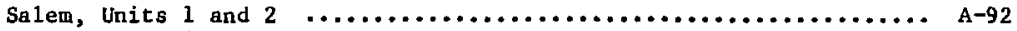

St. Lucie, Unit 1 .................................... A -95

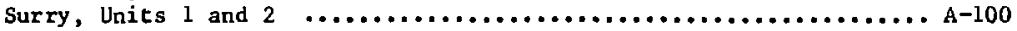

TMI, Unit 1 ........................................ A -103

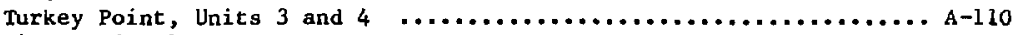

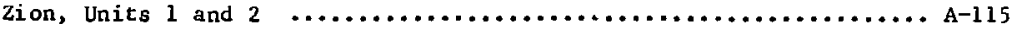

\section{LIST OF TABLES}

$\underline{\text { Table }}$

Page

1-1 Pressurized water reactor licensees $\ldots \ldots \ldots \ldots \ldots \ldots \ldots \ldots \ldots \ldots \ldots . . . \ldots$

i-2 Chronology of licensees' responses to GL $81-14$ and RAI ....... 1-4

S-1 Summary of evaluation results $\ldots \ldots \ldots \ldots \ldots \ldots \ldots \ldots \ldots \ldots \ldots \ldots . \ldots . \ldots$

3-2 Categories of PWR plants in accordance with status of seismic qualification of AFW systems ................. 3-8

3-3 Conditionally qualified areas in the AFW systems of the 40 PWR plants. ................................. 3-10

3-4 Nonqualified areas in the AFW systems of the 40 PWR plants.... 3-11 


\section{ACKNOTLEDGMENTS}

The authorg would like to thank J. T. Beard, NRC Project Manager, for his critical review, comments, and suggestions, T. Y. Chuang, for his technical assigtance, P. D. Smith, NSSP Associate Program Leader at LLNL for his review, ard W. C. Shissler for editing the report. 


\section{EXECUTIVE SUMAPY}

In 1981 the NRC developed and implemented a Multiplant Action Plan C-14, "Seismic Qualification of Auxiliary Feedwater Systems." The intent of the plan was to survey the seismic capability of the AFW systems of all operating PWR plants and, as necessary, require an upgrade of the nonqualified AFW system areas to the SSE level of seismic capability. In the first phase of the C-14 plan, the NRC generated a Generic Letter (GL) 81-14 to all operating PWR 1 icensees requesting information on the seismic capability of their AFW sys tems.

GL 81-14 requested the licensees to perform a walkdown of all presently nonqualified areas in the AFW systen, identify deficiencies amenable to simple remedial actions, and report information regarding the seismic capability of the AFW system. The Lawrence Livermore National Laboratory (LLNL) assisted the NRC by performing the technical evaluation of licensees' responses for 40 operatir.g PWR plants.

The initial screening of licensee' responsses indicated that many of the responses were incomplete. Subsequently, all licensees, with a few exceptions, were issued a Request for Additional Information.(RAI) asking them to provide the complete information as required by GL 81-14. Based on the information provided in the licensees' responses to GL 81-14 and RAT, a TER was prepared by LLNL on a per plant basis. Each TER details the results of our technical evaluation and serves as the technical basis for issuing a Safety Evaluation Report (SER) by the NRC to the licensee.

Our technical evaluation has revealed that, of the 40 operating PWR plants presently involved, $68 \%$ ( 27 plants) have a fully qualified AFW system or an AFW system that will be fully qualified when the licensee completes all planned upgrading modifications. About $25 \%$ ( 10 plants) have minor seismic deficiencies, and only $7 \%$ ( 3 plants) have substantial seismic deficiencies in their AFW systems. For the purpose of this evaluation, the AFW system was divided into seven areas: pumps/motors, valves, piping, water source(s), power supplies, initiation/control systems, and structures that support and/or house the AFW system components.

Our evaluation indicated that all plants either have a qualified primary-water source or have a qualified secondary-water source together with. a switchover procedure where the primary-water source is not qualified. The areas of most frequent deficiencies were piping, valves, structures, and power supplies. For plants that have seismic deficiencies and no plans to upgrade, we recommended the NRC require the licensee to reanalyze and/or modify such nonqualified areas.

Our evaluation also revealed that about $45 \%$ of the plants involved in this study may not have an AFW system boundary that fully conforms to the screening criteria specificed in GL $81-14$, in particular, the criterion for a qualified second isolation valve on the branch $l i n e s$. We did not consider the boundary nonconformance as a major factor in this evaluation. About $35 \%$ of the plants either did not perform the required walkdown of the nonqualified 
AFW system areas or did not cover all nonqualified areas. In this case, we recommended the NRC require the licensee to complete the required walkdown within a reasonable time duration.

Finally, some licensees voluntarily evaluated and/or inspected the seismically-qualified AFW system areas resulting in additional information. In certain cases, this additional information revealed additionai seismic deficiences in the qualified aregs of the AFW system. We recomend that the NRC critically evaluate the significance of such additional information. It appears unfavorable to the pertinent licensee, but it should not be overlooked. 
CHAPTER 1

INTRODUCT ION

Since the incident at Three Mile Island, much attention has been focused on the ability of pressurized water reactors (PWRs) to reliably provide for shutdown decay-heat removal. While it is recognized that alternate methods may be available to remove decay heat, following transients or accidents, heat removal via the steam generator is the first choice for accomplishing the safe shutdown of a PWR plant. The auxiliary feedwater (AFW) system, a safetyrelated system, should be seismically qualified for the Safe shutdown Earthquake (SSE) using criteria consistent with that applicable to other safety-related systems in the plant. However, only those facilities recently designed and licensed are in compliance with the NRC Standard Review Plan, which recognizes the AFW systems as an engineered safety feature.

On August 8, 1980, the NRC Division of Safety Technology (DST) provided the Division of Licensing (DL) of NRC with the results of a study on the seismic capability of decay-heat removal systems. The study included a simplified probabilistic risk analysis and a recommendation for action to be taken by the DL. One of the conclusions of the study vas that the increase in risk during the next three years is sufficiently mall to allow plant operations to continue. Another conclusior was that plants should be surveyed to determine the number of PWR plants that did not have seismically-qualified AFW systems. On October 21,1980 the NRC sent a letter ${ }^{2}$ to all operating PWR licensees to identify the generic concerns and to describe the initial approach for determining the capabilities of operating PWR plants to remove decay heat following an SSE. Information regarding the seismic capability of the AFW system was obtained. informally from the licensees. To better define the scope and depth of the program, site visits to a few plants were made by the NRC ataff.

As a result of the aforementioned actions, the NRC developed and embarked on a Multiplant Action Plan $\mathrm{C}-14$, "Seismic Qualification of Auxiliary Feedwater Systems, "3 One objective of this plan is to increase, to the extent practicable, the capability of those plants without seismicallyqualified AFW systems to withstand earthquakes up to the SSE level. The plan has two phases to accomplish this objective. The first phase includes: (1) to identify via a walkdown of the AFW system, deficiencies amenable to simple remedial actions, and (2) to survey the plants to determine the extent and areas where significant improvements may be needed. The second phase is to complete reanalayses and/or modifications for those plants that do not have an AFW system with demonstrated reasonable assurance of functioning after an SSE. Between these wo phases, the NRC is to make certain decisions and take action to require licensees to make any necessary improvements.

In Generic letter, dated February 10, 1981, (GL 81-14) 4 the NRC requested that all operating $P W H$ licensees complete the AFW walkdowns and report information regarding the seismic capability of their AFW aystems. This action implemented the first phase of the c-14 program. According to . GL 81-14, each licensee was requested to:

(a) Consider the AFW system within those boundaries defined in the Generic Letter. 
(b) Identify the seismic qualification of the AFW system as (1) having been designed, constructed, and maintained as seismic category $I$, (2) having been designed, constructed, and maintained to withstand an SSE, or (3) not fully qualified for an SSE. As a convenience, the AFW system was divided into seven areas, i.e., pumps/motors, piping, valves/actuators, power supplies, water source(s), initiation/control systems, and support structures. The licensee was requested to define the existing level of seismic capabilities for those areas of the AFW systers that are presently not seismically qualified.

(c) Describe the qualification methodology, acceptance criteria, loadings, etc., to achieve the seismic qualification when the AFW system is fully seismicalıy qualified.

(d) Provide the procedure for swi-chover from a nonqualified primary water supply to a seismically-qualified secondary-water supply that can be relied upon.

(e) Indicate the status of compliance of the AFW system with seismic related NRC Bulletins 79-02,79-04, 79-07, 79-14, 80-11 and IE Information Notice 80-21.

(f) Perform a walkdown of those areas of the AFW system that are not presently qualified and, where deficiencies are observed, identify plans for simple remedial actions that will increase their seismic resistance.

(g) When a sizeable lack of seismic qualification of the AFW system is identified, provide the same seismic qualification information as in paragraphs (a) through $(f\rangle$, for an alternate decay-heat removal syatem.

The information provided by the licensee of the Trojan Nuclear Plant in response to GL 81-14 was evaluated directly by the NRC staff and the result was the issuance of a Safety Evaluation Report (SER) for that plant. 5 Moreover, the five PHR plants that were then included in the NRC Systematic Evaluation Program (SEP) were later excluded from the present Lawrence Livermore National Laboratory (LLNL) project subsequent to their responses' to GL 81-14. They were the Haddam Neck and Palisades Muclear Plants, the San Onofre Nuclear Generating Station, Unit 1, the Ginna Nuclear Plant, and the Yankee Rowe Nuclear Plant. The NRC also decided, during the course of their technical reviews associated with the issuance of the operating license for Sequoyah, Unit 1 , that the licensee adequately addressed the seismic capability of the AFW system of Sequoyah, Unit 1, and, hence, no separate review was required. As a result, the remaining 40 operating $P W h$ plants listed in Table $1-1$ became the subjects of this technical assistance program. The technical assistance program has been undertaken by LLNL to provide technical evaluation of the licensees' responses to GL 81-14.

The initial review by LLNL identified that the information contained in most of the licensees' initial responses was not complete or needed clarification. As a result, a Request for Additional Information (RAI) was issued by the NRC to the licensees. Table 1-2 shows the chronology of the licensees' responses to GL $81-14$, the RAI, and the licensees' subsequent responses to the RAI. Based on the additional information provided in the licensees' responses to the RAI and the initial responses to GL $81-14$, we completed our evaluation of the status of seismic qualification of the licelsees' AFW systems. Separate Technica? Evaluation Reports (TERs) were then prepared on a per plant basis and submitted to the NRC to provide them 
with the tachnical basis for issuing a Safety Evaluation Report to each licensee. Additonally, this project report has been prepared to present an evaluative and management summary for the aggregate of all plants involved in this review.

Table 1-1. Pressurized water reactor licensees.

Plant

Arkansas

Arkangaa

Beaver Valley

Calvert $\mathrm{Cliffs}$

Calvert Cliffs

D.C. Cook

D. C. Cook

Crystal River

Davis-Besse

Farley

Farley

Fort Calhoun

Indian Point

Indian Point

Kewaunee

Maine Yankee

McGuire

McGuire

Millstone

North Anna

North Anna

Oconee

oconee

Ocones

Point Beach

Point Beach

Prairie Island

Prairie Island

Rancho Seco

H.B. Robinson

Salem

Salem

St. Lucie

Surry

Surry

TMI

Turkey Point

Turkey Point

Zion

zion
Unit No.

TACS No.

43632

43633

43646

43634

43635

43651

43652

43647

43665

43631

47192

43659

43640

43641

43671

43653

47125

(none)

43656

43666

45673

43643

43644

43645

43669

43670

43657

43658

43663

43636

43661

43674

43643

43667

43668

43654

4364 ?

43650

43637

43638 
Table 1-2. Chronology of liceneees' reoponses to generic letter 81-14 and RAI.

Plant nawe Init Initial response to GL 81-14 RAI Response to RAI

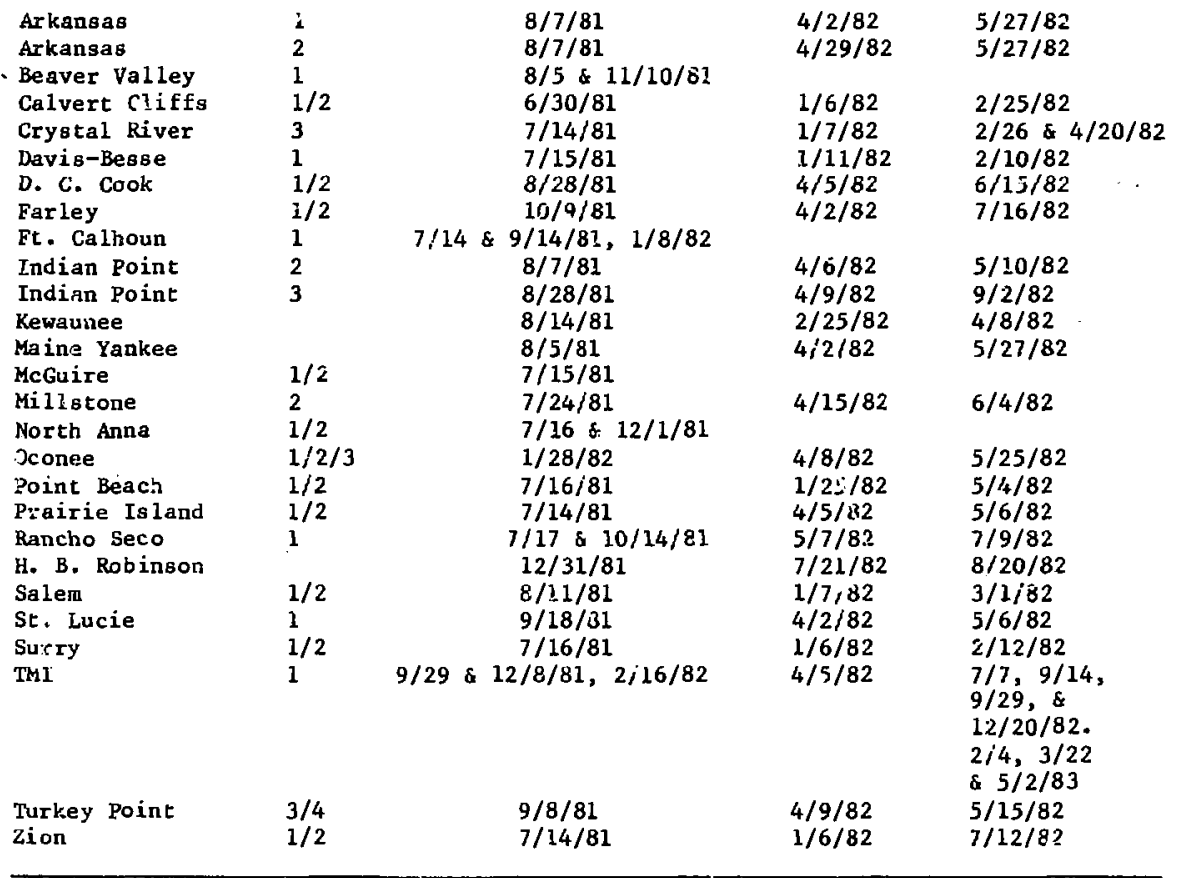

This report is divided into four chapters. Following the Introduction, Chapter \% discusses the general evaluation critaria as well as plant-specifi.c considerations for reviewing the licensees' responses to the GL 81-14 and RAI. Chapter 3 summarizes the results of our reviews. The PWR plants under review have been grouped according to the status of seismic qualification of their AFW systems. The stacus of the AFW system boundary conformance and the required walkdown of seismicaliy nonqualified areas are also discusses in this chapter. The individual TEks for all 40 plants involved in the review are given in the appendix. Chapter 4 sumarizes our conclusions from the review and recommendations to the NRC. 
For the purpose of evaluation, the information contained in each of the licensees' response(s) to the GL $81-i 4$ and the RAI was grouped in accordance with the nature of the information. The result was two general groups:

(1) Information directly pertinent to the seismic capability of the AFW systew, such as the status of seismic qualification, the need for switchover from a seismically-nonqualified primery-water source to a seismically-qualified secondary-water source, the seismic qualification of any alternate decay-heat removal system, the AFW system boundary, the status of compliance with the seismic related NRC Bulletins and Information Notices, the results of walkdown of any seismically nonqualified areas in the AFW system, the completeness of the walkdown, any deficiencies identified during the walkdown, and the licensees' plans for simple remedial measures to remove such deficiencies.

(2) Aditional information not explicitily requesced by the GL 81-14, such as sketches and diagrams of the AFU system, and information on any voluntary evaluation/inspection and voluntary upgrade of the seismically-qualified areas of the A.W system that are not a direct result of either the Generic Letter or the seismic-related NRC Bulletins and Information Notices. The methodology and acceptance criteria for the original seismic design of the AFW components were also considered to be additional information unless, in accomdance with the GL 81-14, the entire AFW system is seismically qualified, in which case this information would be treated as a part of Group (1) information.

Typically, the information in Group (2) was mentioned in the TER without a specific evaluation. The information in Group (1) was reviewed using the general evaluation criteria described in this chapter. There wete, however, cases to which the general evaluation criteria may not be applicable, and plant-specific considerations were applied. The siguiticant plant-specific considerations are discussed following the description of the general criteria.

\subsection{GENERAI EVALUATION CRITERIA}

The overall seismic capability of the AFW system is determined by several factors. These include the status of seiamic qualification of the AFW system components, the conformance of the AFW aystem boundary with the definitiong specified in GL 81-14, che compliance with seismic related HRC Bulletins and Information Notices, the status of seismic qulaification of any available altarnite decay-heat removal systems, and the results of the walkdown of the seiswically nonqualified areas of the AFW system. For convenience of evaluation, the components of an AFW system were categorized into seven areas: pumps/motors, piping, valves/actuators, power supplies, water source(s), initiation/control systems, and structures that support or house the AFW system. The water source(s) as referred to here do not include the supply paths. The suFi' paths were evaluated as a part of the AFW system piping. 


\subsubsection{Status of Seismic Qualification of the AFW Sygtem Components}

The following represent the general criteria for evaluating the status of saismic qualification of the various areas in the AFW system:

(a) The present level of seismic qualification of the AFW system components was evaluated on the basis of the licensees' explicit statements and our own engineering judgement, particularly when the present level of seismic qualification was not available. This is the typical occasion when plant-specific considerations may be required, and is discussed later in greater detail. In any case, we rated a nonqualified component to be "conditionally seismically qualified" regardless of its present level of seismic capability, as long as the licensee provided some plans for modificution/ungrade of the components.

(b) In general, we evaluated the seismic capability of the components within the AFW Jyster boundary presently existirg in the plant. In case the sxisting boundary does not fully conform to the definitions specified in the Generic Letter, such nonconformance was, however, merely identified as a deficiency that is unrelated to our eveluation of the current overall seismic capability of the AFW system.

(c) An AFW systen component was rated as "seismically qualified" if it was originally designed to the seisuic Class 1 or Category I crittria, or, if so stated by the licensee, to withstand the SSE. Within this context, a Design Basis Darthquake (DBE) levil of seismic capability was considered equivalent to the SSE level because some plants were constructed at an earlier time when the term SSE did not exist. We did not evaluate the sufficiency of the methodology and acceptance criteria employed in the licensees' original design of the seismically-qualified AFW syotem components as long as they were consistent with that applicable to other safety-grade systems in the plant. Examples where we accepted the licensees' statement include: the power supplies at Indian Point, Unit 2; the bypassing valve arrangement at Rancho Seco, Unit 1; tive turbine building and the condensate transfer pump foundation at Turkey Point, lnits 3 and 4.

(d) As stated previoubly, tise information about any of the licensees' voluntary evaluation and/or inspection of the AFW system would be considered as additional information unless it was the direct result of the GL 81-14 requirements. For instance, the inspection of any aeismicaliy-qualified areas of the AFW system and the evaluation of any potential interference from seismically nonqualified items outside the AFW system were not explicitly required by GL $81-14$ and, hence, would be treated as additional information. As such, any deficiencies identified through the licensees' voluntary evaluation/inapection were not a factor when we rated the present level of the AFW system.

(e) Nonquaiified components in the AFW system were not construed to degrade the ovrall seismic capability of the AFW system when the licensee stated and/or we juiged that they would not be essential 
to the performance of the reyuired anfety function of the $A F W$ system. Examples include: the power supplies at Crystal River, Unit 3; the initiation/controi aystems at Fort Calboun, Unit 1, Three Mile Island, Unit 1 , and St. Iucie, Unit 1; the 3/4-in. air-operated vent valves (located downstream of the motor-operated steam-admission valves to the AFW turbines) at Turkey Point, Units 3 and 4; etc.

(f) The level of seismic capability of all essential and presently nonqualified items was rated as either "OBE equivaleni" or "Leas than OBE" (Operating Basi'l Earthquake). Our engineering judgement played a major role in the rating and, hence, plant-specific considerations may be required. In general, the "OBE equivalent" rating was given to an item when the licensee stated that the applicable seismic documents were not found, but seismic analysis was required in the original design and/or pruchase specifications, that the item was designed as seismic class II, or that follow-up analyses have indicated the existance of a substantial seismic resistance that was short of the SSE level. Otherwise, the "Jess than $O B E^{\prime \prime}$ rating would be given to the nonqualified item. Examples of the plant-specific considerations are discussed in paragraph 2.2

\section{1 .2 Boundary}

Evaluation of the AFW systew boundary was based on either the sketches and diagrams provided by the licensee, or their statement regarcing compliance of the boundary with the definitions given in GL 81-14. Factors considered in our evaluation included:

(a) the existence on branch lines of a second valve that is normally closed or is capable of automatic closure when required and

(b) the branch lines outside of and seismically coupled to the AFW system, up to a point of three orthogonal restraints. We typically rated the existing AFW system boundary in the licensees' plant as either "fully conforming" or "not fully conforming" to the GL 81-14 boundry definitions. In the event that the sketches and/or the licensees' statement were not specific enough to allow us to reach such a rating, we, in effect, stated that it was not clear whether the AFW system boundary fully conforms to the definitions speciried in GL $81-14$.

As stated in paragraph 2.1.1(b), any nonconforuance of the AFW system boundary with GL 81-14 definitions was merely identified in the TER as a nonseismic-related deficiency.

\subsubsection{Compliance of IE Bulletins and Information Notices}

Based on the licensees' statement, we evaluated as to whether or not the licensees' AFW system has complied with all applicable seismic-related NRC bulletins and information notices. These included the IE Bulletins 79-02, $79-04,79-07,79-14,80-11$, and Information Notice 80-21. The AFW system was given a rating of "full compliance" when the licensee has complied or was in the process of complying with all applicable IE Bulletins and Information 
Notices. The same rating was given when certain IE Bulleting and Information Notices were not complied with and the licensee provided the neceasary justification for waiving the compliance.

We did not consider any current IE Pulletin-related deficienies as affecting our evaluation of the seismic evaluation of the AFW system as long as the licensee was in the process of complying with the applicable IE Bulletins. In addicion, a plant-specific consideration was given to Prairie Is land, Units 1 and 2 .

\section{1 .4 Alternate Decay-Heat Removal System}

In GL 81-14, information regarding the seismic qulaification for any alternate decay-heat removal system was requested if a substantial lack of overall seismic qualificatiom of the AFW system was indicated from the licensees' responses. In our evaluation, we did not specifically define what constituted a "substantial" lack of seismic qualification of the AFW system and, hence, did not specifically request the information on any alternate decay-heat removal system when the :icensees' AFW system is presently not fully seismically qualified. Instead, we inclined to recolmend requesting the licensee to reanalyze and/or upgrade those seismically norqualified areas in the AFW system for which the licensee had no plans to reanalyze/upgrade and did not provide any alternate decay-heat removal system.

A complete evaluation was conducted on the status of seiemis qualification of any alternate decay-heat removal system and the availability of an acceptable procedure for switchover from the AFW system when such information was provided by the licensee. This was the case with Oconee, Units 1, 2, and 3 . The criceria for such evaluation ure similar to those applied to the AFN system.

\section{1 .5 Walkdown of Nong $: 1 i+i \cdot d$ AFW System Components}

For presently nonq _. fied areas of the AFW system, GL 81-14 requested that the licensee perform a walkdown of these areas with personnel experienced in the analysis, design, and construction of the AFW system. In addition, GL 81-14 requested that the licensee propose simple, quick corrective actions, along with schedules, for any deficiencies identified from the walkdown so that the seismic resistance of the deficient nonqualified areas would be increased. Therefore, our criteria for evaluating the required walkdown are as follows:

(a) If the walkdown of all nonqualified areas was found to be incorplete, we would recommend that the licensee be required to complece the walkdown within a reasonable time.

(b) If deficiencies were identified from the walkdown, as indicated by the licensee, we would recommend that the licensee be required to provide the information on corrective actions and schedules, if such information was not provided by the licensee.

Whenever voluntary walkdown was performed by the licensee on the seismically-qualified components of the AFW system, we identified it as "additional information". This was previously mentioned in paragraph 2.1.1(a). 


\subsection{PLANT SPECIFIC CONSIDERATIONS}

As mentioned previously, we have found unique plant situations where the general evaluation criteria were not applicable. We also occasionally deviated from the general evaluation criteria described above, when it was deemed appropriate to do so. In such cases our engineering judgement was involved to a subsantial cegree. Under these circumstences, plant-specific considerations were applied. These are discussed in paragraphs 2.2.1(a) through $(\mathrm{g})$.

\subsubsection{Status of Seismic Qualification of the AFW System}

Typically, we exercised our engineering judgement when the licensee relied on their judgement or other information to substantiate the seismic resistance of certain items in the AFW system. This resulted in the following plant-specific considerations:

(a) We would rate an item as seismically qualified when identical items installed elsewhere or in other plants have been qualified to a seismic level equal to or excceding that required at the plant under review, provided that the original purchase purchase specifications explicitly required a seismic qualification. This was the case, sor example, with the AFW pump turbine and associated trip/throttle valve at Calvert $\operatorname{Cliffs,~Units~} 1$ and 2 ; the conduit supports at St. Lucie, Uniz 1; and the initiation/control systems at Indian Point, Unit 2, On the other hand, we did not accept the licensees' substantiation of seismic qualification on the basis of similarity when the other items in the comparison were qualified to an unspecific seismic level and the item under review was purchased without specific seismic requirements. This was the case, for example, with all the manual valves in the Calvert Cliffs, Units 1 and 2 , to which we gave an "OBE equivalent" rating based on our best judgement.

(b) Nonqualification of the primary water supply lines was considered nonessential to the overall rating of the seismic capability of the AFW system piping, when a seismically-qualified secondary-water source and supply path exists and an acceptsule switchover procedure is available. This was the case with the D. C. Cook, Units 1 and 2 and Zion, Units 1 and 2.

(c) We rated an item as seismically qualified when the licensee substantiated, on a generic basis, that the said item can withstand a seismic level substantially higher than required. For instance, the AFW motor and air-operated gate and globe valves at Indian Point, Unit 2, were purchased without specific seismic requirements and the licensees' consultant had analytically established their generic seismic capacity to be from $2.84 \mathrm{~g}$ to $23 \mathrm{~g}$, with a medium value of $7.3 \mathrm{~g}$. Moreover, the licensees' consultant established the $m_{2} \cdot d i u m$ ground-acceleration capacity of the AFW water-regulator valves and steam-inlet valve at Indian Point, Unit 2, to be about 5g. Based on this data and assuming a log-normal distribution for the generic data, we estimated the lower-bound ground-acceleration capacity of the water-regulator valves and steam-inlet valve to be approximately $0.58 \mathrm{~g}$. The design ground-acceleration for Indian Point, Unit 2 was $0.15 \mathrm{~g}$. Hence, we rated all of the above-mentioned valves to be seismically quslified. 
(d) For Indian Point, Unit 3, we did not accept the licensee's statement about the nonessentiality of the nonqualified valve, $L C V-1128$, and the pipe between the said valve and a seismically-qualified valve, LCV-1158. We rated both of them to be "Less than OBE". Such a rating was given because of our belief that, if the pipe under consideration should break during a seismic event, and the single failure asaumed to be the qualified isolation valve, LCV-1158, a path woulr: be created that would jeopardize the capability of the water source to deliver an adnquate amount of water to the AFd system.

(e) When the "OBE equivalent" rating was given to a nonqualified item, it usually involved a very subjective judgement from us. For example, we gave the same ráing to the manual valves at calvert cliff 5 , Units 1 and 2,28 mentioned in subparagragh (a) above. He also gave this rating to the overall seismic capacity of the AFW system piping at D. C. Cook, Units 1 and 2, because the main feedwater piping downstream from the check valve to the motor-operated valve is seismic class III and was designed to withstand oxly the $O B E$.

(f) According to the general criteria [paragraph 2.1.1(b)], we would evaluate only the AFW system piping, within the existing boundary at the plant, even though the boundary might not fully conform to GL 81-14 definitions. We deviated from this general criteria, however, for the Occnee, Units 1,2 , and 3 , because the licensees indicated that all branch lines beyond the first valves are nonqualified, where ouch first valves are considered to be the exisitng AFW system boundary. In other words, we would consider it a seismic-related deficiency for any licensee-identified nonqualified piping beyond the first valves that represent the existing AFW system boundary.

(g) The sheet-metal enclosure structure, which is on the suction side of and close to the condensate storage tank, at D. C. Sook, Units 1 and 2 , represent a unique case. The structure is not seismic Class I, but houses a seismic class I first valve and about three feet of seismic Class I piping. We rated the structure to be seismic qualified; however, the rating would be reduced to "OBE equivalent" if the segment of piping protected by the enclosure is an essential AFW water supply line.

\section{2 .2 Boundary}

Where the icensee indicated their existing AFW system boundary to be not fully conforming to GL 81-14 definitions, we still gave a "full conformance" rating when the licensee presented auficient justification for the boundary

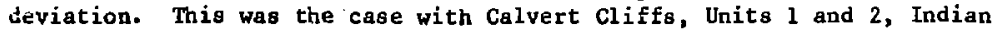
Point, Unit 2, North Anna, Unite 1 and 2, Salem, Units 1 and 2, and Three Miles IBland, Unit 1.

\subsubsection{Compliance of IE Bulletins and Information Notices}

The licensee of Prairie Island, Units 1 and 2, has stated that they do not comply with Information Notice 80-21, and will defer any reviewing action 
until 1984. We did not consider this as a seismic-related concern in our evaluation of the AWW electrical systems at Prairie Island, Units 1 and 2.

\subsubsection{Walkdown of Nonqualified AFW System Arees}

The 1 icensee of D. C. Cook, thits 1 and 2, did not perform a walkdown of the nonqualified sheet-metal enclosure that is on the suction side of and close to the condensate storage tank. In the TER, however, we did not recommend requiring the licensee to complete this walkdown, because, as previously discussed in the plant-specific consideration example [paragraph 2.2.1 $(\mathrm{g})]$, the enclosure structure is a nonessential item unless the segment of piping protected by the enclosure structure is an essential water supply line. As another example, the licensee of Indian Point, Unit 2, did not specifically state that their walkdown covered all nonqualified AFW system items. However, we believed that additional walkdown is not required, because there were previous walkdowns performed by both 1 icensee and the NRC resident inspector and appeared to have covered more than just the nonqualified areas. In addition, the walkdown performed by the NRC resident inspector fid not identify any unacceprable conditions. 
CHAPTER 3

EVALUATION RESULTS

The respanses, from the licensees of the 40 PWR plents under review, were evaluated usirg the general criteria and plant-specific bases that were delineated in Chapter 2. A summary of the evaluation results is shown in Table 3-1. The status of seismic qualification of each of the seven AFW system areas in Table 3-1 is represented by:

(a) a blank indicating "presently seismically qualified,"

(b) a bracketed footnote in a blank indicating "conditionally seismically qualified,"

(c) a numeral " 1 " accompanied by a bracketed footnote indicating an "OBE equivalent"вei.amic level, or

(d) a numeral "2" accompanied by a bracketed footnote indicating a "Less than OBE" seismic level.

In both (c) and (d), the footnote explains the plant-specific basis for reaching the associated rating. A "No" in any column of Table 3-1 represents a partial or total noncompliance with the applicable requiremer.ts of the GL 81-14.

The significant apects of the results of our evaluation are discussed in paragraphs 3.1 through 3.5 for the status of overall seismic qualification, AFW system boundary, walkdorm, alternate decay-heat removal system, and additional information, respectively. The evaluation generated a TER for each of the PWR plants involved. These are included in the appendix. The TER contains the details of our evaluation, conclusions, and recoumendations for each plant. 


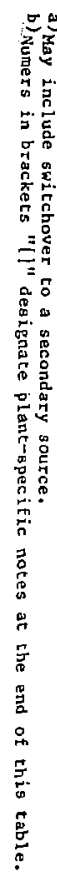

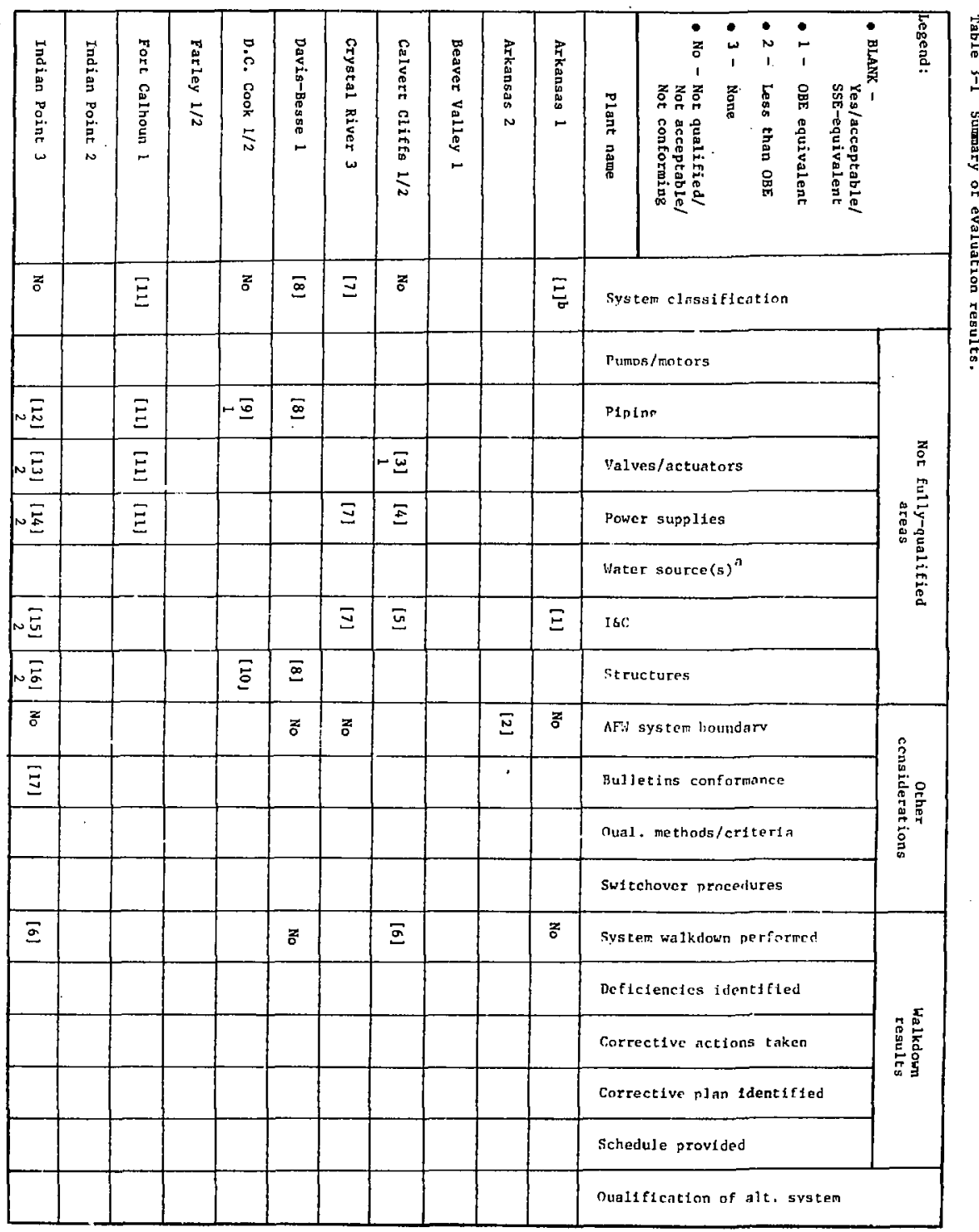




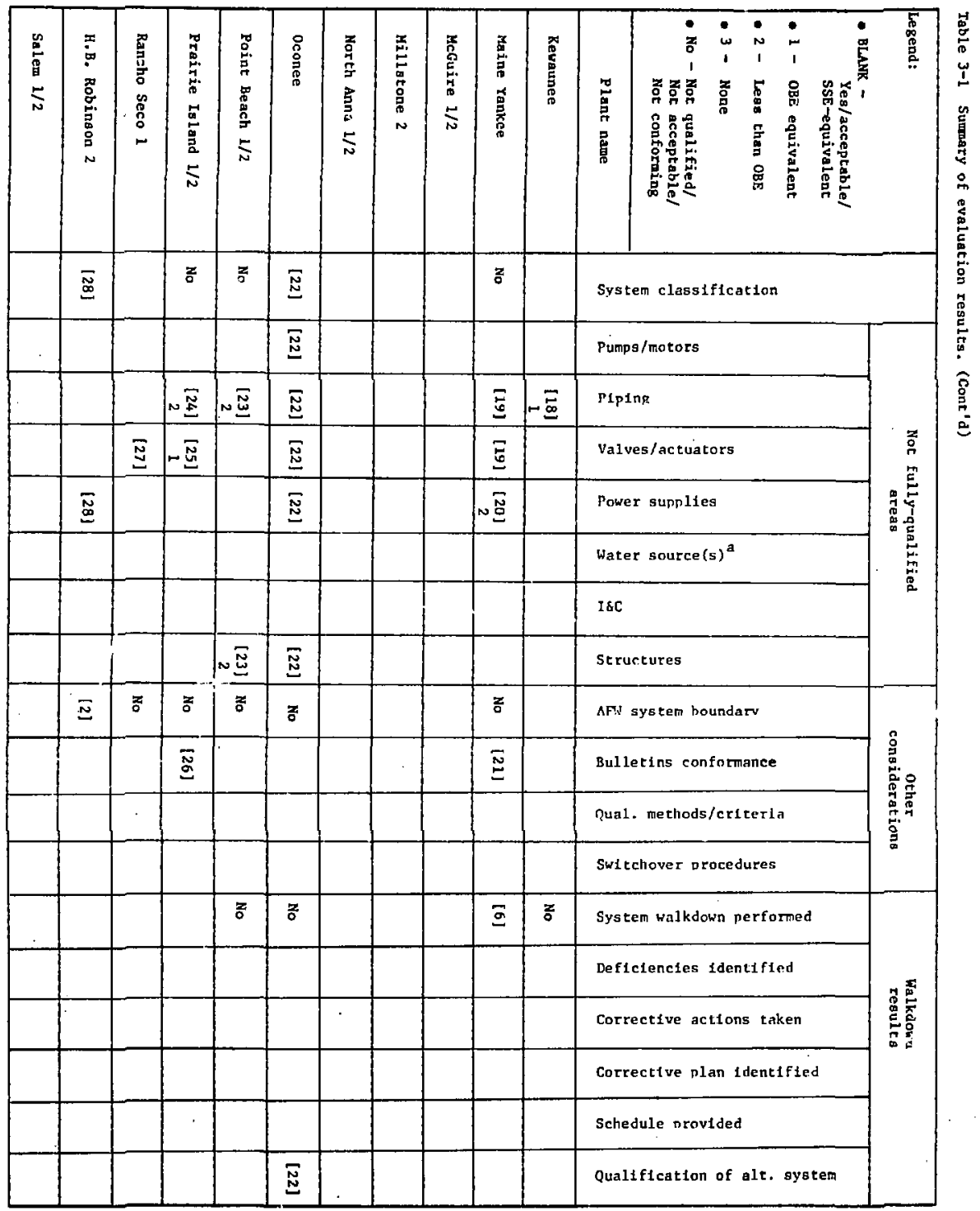




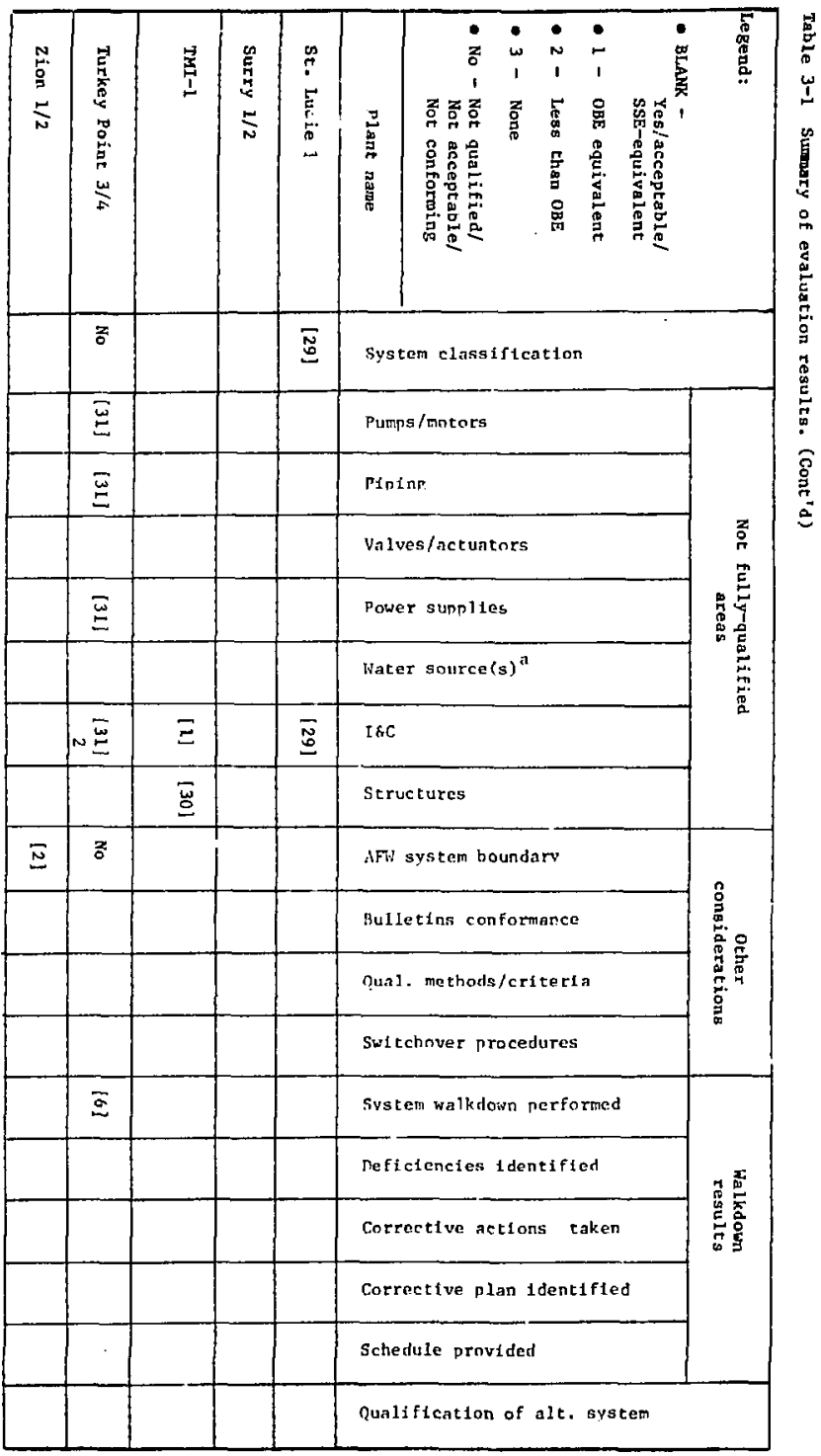




\section{PILANT-SPECIFIC NOTES FOR TABLE 3-1}

1. Not all components of the I\&C system are currently seismic qualified, but they will be upgraded to seismic qualification after the next refueling outage.

2. It is not clear whether the AFW system boundary fully conforms to GL 81-14 definitions:

3. All manual valves, except for the penetration and condensate storage tank No. 12. discharge valve, were purchased without seismic qualification. These valves probably possess an OBE level seismic capability becaupe they are similar in material and construction to others that have been qualified to a certain unspecified seismic level.

4. All circuit carrying conduits will be upgraded to Class $1 \mathrm{E}$ during thegeneraI AFW system modification.

5. The Burbon tube-type pressure indicators and the tucbine trip hand-switches are nonseismic class $I$. They are being upgraded under the general AFW modification.

6. Walk-down of nonseismicaldy-qualified components has been performed, but it is not complete.

7. The current seismic capability is unknown, but nonseismically-qualified items will be upgraded.

8. The auxiliary feedwater pump, turbine pipe support, and certain masonry walls are not seismically qualified, but modification will be completed.

9. The main feedwater piping upstream from the check valve to the MOV is seismic Class III, but was designed to USAS B31:1 (1967) to withstand an OBE.

10. The seismic leve $i$ becomes OBE if the segment of piping covered by the nonseismically qualified sheet-metal enclosure structure on the suction side, close t's the condensate storage tank, is not a part of the primary water supply path.

11. The following areas are currently nonseismatically qualified:

(a) small-bore piping in both cold and hot systems, (b) valve operators on amall-bore piping, and (c) electric supply conduit to the AFW pump, FW-6 motor. They are subject to modifications.

12. Branch piping CT-1070 is seismic Class III. No plans are made for upgrading.

13. Valve LCV-1128 is seismic Class III. No plans are made for upgrading.

14. Original seismic design level is not available for the motor control centers (MCC) 34 and 39, 480 switchgear Nos. 31 and 32 , and 125-VDC power panels Nos. 31, 32, and 33. Investigations are to be completed by the summer of 1984 . 


\section{PLANT-SPECIFIC NOTES FOR TABLE 3-1 (COnt'd)}

15. Seismic documentation is not available for the turbine AFW pump, speed control system, and flow control switches, EC-1135s and FC-1136S static " $O$ " ring. Investigations are to be completed by the summer of 1984.

16. The turbine building is seismic class III. No plans are made fnr upgrading.

17. IE Information Notice, 80-21, is under review.

18. The licensee is currently verifying the seismic design of the additional branch piping due to licensee's relocation of the class I boundary : and will sutmit their findings at a later date.

19. Currently, (a) small-bore minimum-flow recirculating piping, (b) majority of large-bore suction piping, (c) small-bore piping, and (d) all actuators are not oeismically odalified, but corrective actions will be implemented to assure the SSE capability of the AFW system.

20. Seismic capacity of conduit is currently unknown, and lisensee will assess the feasibility of qualifying the conduit, at tiue permits.

21. The AFW system will comply with all seismic related NRC Bulletins and Information Notices when the licensee completes their seismic qualification assessment program.

22. Currently, nonseismically-qualified areas include all but water source(s) and initiation/control systems. According to the licensee's responses, a seismically-qualified standby-shutdown facility is being constructed to provide a dedicated, separate train of auxiliary feedwater.

23. Branch lines No. 20 to 28 were not originally seismically designed. Except for the control building, other buildings are not seidmic Class I. Currently, the licensee has no plan for upgrading these deficiencies.

24. All identified modifications will be completed prior to or during Units 1 and 2 refueling outages in 1983 .

25. Certain VELAN valves are not seismically qualified. They are judged to possesss on OBE level of resistance because seismic analysis was required by purchase specifications. No plans are made for upgrading.

26. The licensee is deferring any action on IE Information Notice 80-21 pending on NRC's issuance of the Rule and Regulatory Guide expected in 1984.

27. Air-operated valves, FV20526 and FV20527, were not qualified to any seismic requirements. However, they were bypassed by seismically-qualified motor-operated valves, SFV 20577 and SFV20578. 


\section{PLANT-SPECIFIC NOTES FOR TABLE 3-1 (Cont'd)}

28. The adequacy of the seismic qualification of electrical cables and motor control centers is under evaluation in compliance with $Z E$ Information Notice 80-21.

29. The control-grade automatic-initiation circuitry was upgrsded to seismic Category I during the September 1981 outage.

30. The turbine building is seismic Class II, but was judged nonessential.

31. Currently, pumps/motors, piping, power supplies, and I\&C systems are not fully, seismically qualified but, except for I\&C systems, they will be modified/upgraded to the SSE level. 


\subsection{STAYUS OF OVERALL SEISMIC QUALIFICATION}

Based on our evaluation, the 40 operating PWR plants under review may be categorized into four groups in accordance with the status of overall seismic qualification of the AFW system, as shown in Table 3-2:

(1) Fully Qualified - Those plants with an AFW system that is presently fully qualified. There are 18 (45\%) plants in this category.

(2) Conditionally Qualified - Those plants with an AFW system that presently has certain seismic-related deficiencies, but will be able to withstand an SSE upon completion of the upgrading/modification programs planned by the licensee. This includes six plants $(15 \%)$.

(3) Minor Deficient - Those plants with an AFW system that has, according to our engineering judgement, "minor" seisuic deficiencies and for which no specific plans for upgrade/modification were provided by the licensees. There are ten plants $(25 \%)$ in this calegory.

(4) Majur Deficient - Similar to Group 3 plants, but with "rajor" seismic deficiencies in the AFW system. The remaining six plants (15\%) belong to this category.

Table 3-2. Categories of PWR plants in accordance with status of seismic qualification. of AFW systems.

\begin{tabular}{|c|c|c|c|}
\hline $\begin{array}{c}\text { Group } 1 \\
\text { Fully } \\
\text { qualified }\end{array}$ & $\begin{array}{l}\text { Group } 2 \\
\text { Conditionally } \\
\text { qualified }\end{array}$ & $\begin{array}{l}\text { Group } 3 \\
\text { Minor } \\
\text { deficient }\end{array}$ & $\begin{array}{c}\text { Group } 4 \\
\text { Major } \\
\text { deficient }\end{array}$ \\
\hline $\begin{array}{l}\text { Arkansas, } 2 \\
\text { Beaver Valley, } 1 \\
\text { Farley, } 1 / 2 \\
\text { Indian Pt., } 2 \\
\text { McGuire, } 1 / 2 \\
\text { Millstone, } 2 \\
\text { North Anna, } 1 / 2 \\
\text { Rancho Seco, } 1 \\
\text { H.B. Robiason, } 2 \\
\text { Salem, } 1 / 2 \\
\text { Surry, } 1 / 2 \\
\text { Zion, } 1 / 2\end{array}$ & $\begin{array}{l}\text { Arkansas, } 1 \\
\text { Crystal River, } 3 \\
\text { Davis-Besse, } 1 \\
\text { Ft. Calhoun, } 1 \\
\text { St. Lucie, } 1 \\
\text { TMI, } 1\end{array}$ & $\begin{array}{l}\text { Calvert Cliffs, } 1 / 2 \\
\text { D. G. Cook, } 1 / 2 \\
\text { Maine Yankee } \\
\text { Kekraunee } \\
\text { Prairie Island, } 1 / 2 \\
\text { Turkey Pt., } 3 / 4\end{array}$ & $\begin{array}{l}\text { Indian Point, }{ }^{3} \\
\text { Oconee, } 1 / 2 / 3^{*} \\
\text { Pt. Beach, } 1 / 2\end{array}$ \\
\hline 18 units & 6 units & 10 units & 6 units \\
\hline
\end{tabular}

* Has a conditionally-qualified alternate decay-heat removal system (the standby shutdown facility, SSF). 
It must be noted, that since Oconee, Units 1,2 , and 3 , have a conditiona!ly-qualified alternate decay-heat removal system (SSF) under construction, the overall decay-heat removal capability will be fully qualified once che SSF modification is completed.

Thus about $60 \%$ of the plants have a fully or condjtionally-qualified AFW system ( $68 \%$ if Oconee, Units 1, 2, and 3, AFW systems are rated "conditionally qualified"), twenty-five percent of the piants have a winor deficient AFW system, and only $15 \%$ have a major deficient AFW syatem (or $7 \%$ if Oconee may be excluded).

We found that all plants have seismically-qualified water sources. Ei iner the primary water source is seismically qualified, or a qualified secondary-water source exists, and a procedure for switchover from the primary water source is available. For the other six areas in the AFW system, the statistics of conditional qualification and nonqualification for the 40 plants reviewed are presented in Tables $3-3$ and $3-4$, respectively. Baved on Table $3-3$, statistics of conditional qualification are as follows:

$\begin{array}{ll}\text { - } & \text { Water source(s) } \\ \text { - Structures } \\ \text { - Vumps/motors } \\ \text { - Piping/actuators } \\ \text { - Initiation/control oystems } \\ \text { - Power supplies }\end{array}$

- none

- 1 plant

- 2 plants

- 2 plants

- 5 plants

- 5 plants

- 7 plante

For nonqualification, Table 3-4 gives the following statistics:

$\begin{array}{ll}\text { - Water source(s) } & - \text { none } \\ \text { - Pumps/motors } & -3 \text { plants } \\ \text { - Initiation/control systems } & -3 \text { plants } \\ \text { - Power supplies } & -5 \text { plants } \\ \text { - Vtructures } & -6 \text { plants } \\ \text { - Piping } & -8 \text { plants } \\ \text { - } & -11 \text { plants }\end{array}$

From this sumary, we conclude that the most frequently deficient areas are: piping, valves, structures, and power supplies. In general, older plants have more conditionally qualified and nonqualified items.

This is anticipated, because the older plants were probably constructed prior to the NRC's issuance of the Standard Review Plan, which specifies that the AFW system is a safety-grade system.

\subsection{BOUNDAKY}

For the AFW system boundaries in most plants, either they do not fully conform to or it was nce clear from the licensees responses that they fully conform to the defintions given in GL 81-14. Table 3-1 indicates that, out of the 40 plants under review, 14 plants (or 35\%) have a nonconforming AFw system boundary, and four plants (or 10\%) have an AFW system for which we could not determine if the boundary fully conforms to the GL $81-14$ definitions. 
Table 3-3. Conditionally-qualified areas in the AFW systems of the 40 PWR planta.

\begin{tabular}{|c|c|c|c|c|c|c|}
\hline Plant name & Structures & $\begin{array}{l}\text { Pumps/ } \\
\text { notors }\end{array}$ & $\begin{array}{c}\text { Valves/ } \\
\text { actuators }\end{array}$ & Piping & $I \& \mathrm{C}$ & $\begin{array}{c}\text { Power } \\
\text { supplies }\end{array}$ \\
\hline $\begin{array}{l}\text { Arkansas } 1 \\
\text { Arkansas } 2 \\
\text { Beaver Valley } 1 \\
\end{array}$ & & & & & $\mathbf{x}$ & \\
\hline $\begin{array}{l}\text { Calvert Cliffs } 1 / 2 \\
\text { Crystal River } \\
\text { Davis-Besse } 1\end{array}$ & $\mathrm{X}$ & & & $\mathbf{x}$ & & \\
\hline $\begin{array}{l}\text { D.C. Cook } 1 / 2 \\
\text { Farley } 1 / 2 \\
\text { Fort Calhoun } 1 \\
\end{array}$ & & & $\mathbf{X}$ & $\mathbf{x}$ & & $\mathrm{X}$ \\
\hline $\begin{array}{l}\text { Indian Point } 2 \\
\text { Indian Point } 3 \\
\text { Kewaunee }\end{array}$ & & & & & & \\
\hline $\begin{array}{l}\text { Maine Yankee } \\
\text { McGuire } 1 / 2 \\
\text { Millstone } 2 \\
\end{array}$ & & & $\mathrm{x}$ & $\mathrm{x}$ & & \\
\hline $\begin{array}{l}\text { North Anna } 1 / 2 \\
\text { Oconee } 1 / 2 / 3 \\
\text { Point Beach } 1 / 2\end{array}$ & & & & & & \\
\hline $\begin{array}{l}\text { Prairie Island } 1 / 2 \\
\text { Rancho Seco } 1 \\
\text { H.B. Robinson }\end{array}$ & & & & & & \\
\hline $\begin{array}{l}\text { Salem } 1 / 2 \\
\text { St. Iucie } 1 \\
\text { Surry } 1 / 2 \\
\end{array}$ & & & & & $\begin{array}{l}\mathrm{x} \\
\mathrm{x}\end{array}$ & \\
\hline $\begin{array}{l}\text { TMI } 1 \\
\text { Turkey Point } 3 / 4 \\
\text { Zion } 1 / 2\end{array}$ & & $\mathrm{x}$ & & $x$ & & $\mathrm{x}$ \\
\hline Total No. of plant & $=6$ & 2 & 2 & 6 & 5 & 6 \\
\hline
\end{tabular}

HOTE: No plant has sonditionally-qualified water source(s). 
Table 3-4. Nonqualified areas in the AFW oystems of the 40 PWR plants.

\begin{tabular}{|c|c|c|c|c|c|c|}
\hline Plant name & Structures & $\begin{array}{l}\text { Pumpa / } \\
\text { motors }\end{array}$ & $\begin{array}{c}\text { Valves! } \\
\text { ectuetors }\end{array}$ & Piping & I\&C. & $\begin{array}{l}\text { Power } \\
\text { supplies }\end{array}$ \\
\hline $\begin{array}{l}\text { Arkansas } 1 \\
\text { Arkansas } 2 \\
\text { Beaver Valley } 1 \\
\end{array}$ & & . & $\mathbf{x}$ & . & & . \\
\hline $\begin{array}{l}\text { Calvert Cliffs } 1 / 2 \\
\text { Crystal River } \\
\text { Davis-Besse } 1 \\
\end{array}$ & & & & & & . \\
\hline $\begin{array}{l}\text { D.C. Cook } 1 / 2 \\
\text { Farley } 1 / 2 \\
\text { Fort Calhoun } 1 \\
\end{array}$ & & & & $\mathrm{x}$ & & \\
\hline $\begin{array}{l}\text { Indian Point } 2 \\
\text { Indian Point } 3 \\
\text { Kewaunee }\end{array}$ & $x$ & & $x$ & $\begin{array}{l}x \\
x \\
\end{array}$ & $\boldsymbol{x}$ & $x$ \\
\hline $\begin{array}{l}\text { Maine Yankee } \\
\text { McGuire } 1 / 2 \\
\text { Millstone } 2 \\
\end{array}$ & & & . & & & $x$ \\
\hline $\begin{array}{l}\text { North Anna/2 } \\
\text { Oconee } 1 / 2 / 3 \\
\text { Point Beach } 1 / 2 \\
\end{array}$ & $\begin{array}{l}x \\
X \\
\end{array}$ & $\mathrm{X}$ & $x$ & $\begin{array}{l}x \\
x \\
\end{array}$ & & $x$ \\
\hline $\begin{array}{l}\text { Prairie Ialand } 1 / 2 \\
\text { Rartcho Seco } 1 \\
\text { H.B. Robinzon }\end{array}$ & & & $\mathrm{X}$ & $\begin{array}{l}x \\
x\end{array}$ & & \\
\hline $\begin{array}{l}\text { Salem } 1 / 2 \\
\text { St. Lucie } 1 \\
\text { Surry } 1 / 2 \\
\end{array}$ & & & & & & . \\
\hline $\begin{array}{l}\text { TMI } 1 \\
\text { Turkey Point } 3 / 4 \\
\text { Zion } 1 / 2\end{array}$ & & & & $:$ & $X$ & \\
\hline Total No. of plants & 6 & 3 & 8 & 11 & 3 & 5 \\
\hline
\end{tabular}

NOTE: No plant has nonqualified water source $(s)$. 
Together, about $45 \%$ of the plants have an AFW system with a boundary that does not or may not fully conform to GL 81-14 definitions. In general, the nonconformance of the boundary was attributed to: (a) in most cases, the lack of a second valve on branch lines that is normally closed or capable of automatic closure, and/or (b) the lack of seismic qualification of the branch piping beyond the AFW system boundary, up to a point of three orthogonal restraints, where the branch piping is seismically coupled to the AFW system. It is no surprise that the main reason for the nonconformance in the AFW system boundary is the lack of a second isolation valve on the branch lines. The GL 81-14 requirement on double-isolation valves was used by the NRC as screening criterion. Double valves are acceptable immediately without review. If double valves are not provided, the system may be acceptable if the single failure criterion is satisfied, or if the licensee justifies the design on some other basis.

\subsection{WALKDOWN}

The walkdown requested by GL $81-14$ was intended to come up with simple remedial actions, together with a schedule, to correct any identified deficiencies of the presently nonqualified item in order to increase their seismic resistance. Our review indicated that, according to Table 3-1, eight plants (20\%) did not perform any of the required walkdown, and six plants (15\%) did not completely walkdown all nonqualified itens. On the other hand, for some plants the licensees not only installed quick, simple fixes for the deficiencies identified during the walkdown, but also proposed long-term upgrade/modification programs that were not explicitly required by GL $81-14$. Moreover, some licensces even performed a voluntary walkdown of the qualified areas and installed quick fixes for the identified deficiencies, as discussed in paragraph 3.5

\subsection{ALTERNATE DECAY-HEAT REMOVAL SYSTEM}

Out of the 40 plants, only Oconee, Inits 1, 2, and 3 , will rely upon an alternate decay-heat removal system. Denoted as a standby shutdown facility, the system is conditionally qualified in accordance with our evaluation. Therefore, Oconee, Units 1, 2, and 3 , may be considered to hve an overall conditionally-qualified decay-heat removal facility although their AFW systems have major seismic deficiencies and are categorized as major deficient in Table 3-2.

\subsection{ADDITIONAL INFORMATION}

The additional information provided by the liceasees, which was not a direct request of the GL $81-14$, included the following:

(a) Schematic sketches and diagrams of the AFW system. They usually provided information regarding the existence of a second valve on branch lines, the seismic boundary, water sources, piping, and other major equipment, etc.

(b) The results of voluntary walkdown of seismically-qualified areas and any licensees' proposed corrective actions. 
(c) Description of the methodologies and acceptance criteria for seiamically-qualified areas when the AFW system is not fully qualified. However, if the AFH system is fully qualified, the methodologies would be discussed in paragraph 2.1.1, Status of Seismic Qualification of AFW System Components:

(d) Identification of areas of voluntary modification/upgrade that have been or were being implemented by the licensee, but we se not a direct result of GL $81-14$.

(e) In the case of Inoian Point, Unit 3, results of an interaction study of nonqualified items outside of the AFW system that may have a potential to damage or interfere with the AFW system function following an SSE.

We found that the schematic sketches/diagrams of the AFW syatem have usually been very helpful to our evaluation of the AFW system boundary and, sometimes, the seismic capability of certain piping. In addition, $n$ ?though we did not specifically evaluate any of the additional information, the additional information provided us a better understanding of the seismic capability of the AFW system with respect to the modern day seismic design practice for a safety-grade system. Apparently, some licensees performed the voluntary evaluation and/or upgrade of their AFW systems with the modern day design practice although GL $81-14$ required only that the AFW syatem be originally designed to methodologies and criteria consistent with those applicable to other safe-grade systems at the plant. The licensee of Indian Point, Unit 3, went beyond the GL $81-14$ requirements by performing the interaction study to assure the required safety function of the AFW system following an SSE. On the other hand, it has been noted that the additonal information could expose more deficiencies in the seismic capabilities of the AFW system. Since each licensee provided different amounts of additional information, it could happen that some AFW systems appear inferior in seismic capability to the others simply because the licensees of the former volunteered more addicional information than the latter. It has been our opinion that the licensees should not be penalized for deficiencies identified while providing additional information. Meanwhile, we strongly feel that any deficiencies so identified should not be completely overlooked. Such ironic observation has led us to wonder what deficiencies could have also been discovered if other licensees had similiarly performed additional investigations and inspections. 
In sumnmary, we prepared a TER (Technical Evaluation Report) for each of the 40 operating PWR plants as listed in Table 1-1. The evaluation was based on the licensees' responses to GL 81-14 and Request for Additonal Information (RAI). The significant results of our evaluation were previously discussed in Chapter 3. The individual TERs are a part of the apperdix. The general evaluation criteria and anj plant-specific considerations were delineated in Chapter 2 .

The following conclusions are made with regard to our evaluation of the licensees' responses:

(1) In general, the plants involved in the review can be divided into four categories in accordance with the status of seismic qualification of the AFW systems, i.e., fully qualified, conditionally qualified, minor deficient, and major deficient, as shown in Table 3-2. About $68 \%$ of the plants are in the first two categories (including the conditionally-qualified standby shutdown facility at Oconee, Units 1,2 , and 3 , as the alternate decay-heat removal system), $25 \%$ are minor deficient, and only $7 \%$ are major deficient.

(2) All plants have a qualified primary or secondary-water source. Secondary water sources have a switchover procedure to facilitate the switchover when required. For the other six AFW system areas, i.e., pumps/motors, piping, valves/actuators, power supplies, initiation/control systems, and structures, the statistics of conditionel qualifiacation and nonqualification are shown in Tables 3-3 and 3-4, respectivel'- The most frequent $1 y$ deficient areas are: piping, valyes/actuators, structures, and power supplies. Usually the older plants have more deficient items because they were constructed prior to the issuance of the Standard Review Plan and, hence, their AFW systems may not have been designed originally as a safety-grade system.

For 14 plants $(35 \%)$, we determined that the AFW system boundary did not fully conform to the requirements of GL 81-14. In addi:ion, there were four plants $(10 \%)$ where we were unable to fully review cine conformance condition of the AFW system boundary. Most of the plants with a nonconforming AFW syster boundary do not have double-isolation valves on branch lines. Altogether, $45 \%$ of the plants do not or may not have their AFW system boundary fully conforming to GL $81-14$ definitions.

(4) For those plants presently having nonqualified AFW system items, many licensees did not complete the required walkdown. In particular, a walkdown has usually not been conducted for the nonfualified structures that support or house essential AFW items. 
(5) Licensees usually provided adjitional information such as sketches/diagrams, methodologies and criteria for the original seismic design, voluntary walkdown of the seismically-qualified areas, and long-term voluntary upgrade of the AFW system. In the case of Indian Point, Unit 3, the licensee submitted an interaction study on the potential damaging effect of nonqualified items outside the AFW system in the event of a seismic event. The additional information helped us evaluate the seismic capability and boundary conformance of the AFW system.

(6) Oconee, Units 1, 2, and 3, are the only plants that will rely ou an alternate decay-heat removal system: the Standby Shutdown

Facility. This system was rated as conditionally qualified.

Our recommeniations to the NRC regarding the licensees' responses to GL 81-14 and RAI are as follows:

(1) In the TER, we generally recommend that the NRC require the licensee to reanalyze and/or modif, the nonqualified AFW system items, if a plan for such corrective action was not provided by the licensee.

(2) Regarding the required walkdown of nonqualified areas, we recommend that NRC define what constitutes a reasonable tine schedule for the licensee to complete their proposed quick fixes to any identified deficiencies, and a reasonable time schedule to complete the required walkdown of all nonqualified items whenever the walkdown is found incomplete.

(3) In general, our evaluation indicated that the more information that could be provided by the licensee the more the potential weaknesses in the seismic capability of the AFW system would be exposed. As such, an AFW system may appear inferior to others simply because the $\mathrm{licensee}$ provided more additional information while, in reality, the reverse may be true. This is a very important aspect for which the NRC must take a prudent position so that no licensees would be unnecessarily penalized simply because they provided more information. On the other hand, it appears that the NRC may not want to ignore any seismic related deficiencies identified in the licensees' additional information. Therefore, we recommend that the NRC evaluate the significance of all voluntary investigations and/or inspections that resulted in the additional information provided by ceratin licensees. One good example is the interaction study performed by the Indian Point, Unit 3, licensee that was intended to investigate the potential interference and damage to AFW functions should any nonqualified components outside the AFW system boundary rail. 
1. R. J. Mattson, "Analysis and Recxommendations Related to Plants Without Seismically Qualified Auxiliary Feedwater Systems," U.S. Nuclear Regulatory Commission, Division of Safety Technology, memorandum to D. G.Eisenhut, Division of Licensing (August 8, 1980).

2. D. G. Eisenhut, "Seismic Qualification of Auxiliary Feedwater Systems," U.S. Nuclear Regulatory Commission, letter to all operating pressurized water reactor licensees (October 21, 1980).

3. D. G. Eisenhut, "Multiplant Action Plan C-14: Seismic Qualifications of Auxiliary Feedwater Systems," memorandum to H. R. Denton, Office of Nuclear Reactor Regulation (February 20, 1981).

4. D. G. Eisenhut, "Seismic Qualification of Auxiliary Feedwater Systems," Generic Letter 81-14, U.S. Nuclear kegulatory Comission, letter to all operating pressureize water reactor 1 icensees (February 10, 1981).

5. K. A. Clark, "Safety Evaluation Keport for the Trojan Nuclear Plant", U.S. Nuclear Regulatory Commission, letter to B. D. Withers of the Portland General Electric Company (August 4, 1981). 
APPENDIX

TECHNICAL EVALUATION REPORTS 


\section{SE ISMIC QUALIFICATION OF AUXILIARY FEEDWATER SYSTEM TECHNICAL EVALUATION REPORT}

ARKANSAS NUCLEAR ONE: UNIT 1

\section{INTRODUCTION}

Since the accident at Three Mile Island Nuclear Station, considerable attention has been focused on the capability of nuclear power plants to reliably remove decay heat. The subject of this evaluation is the NRC Multiplant Action Plan C-14, "Seismic Qualification of ATW Systems."l

To implement the first phase of $\mathrm{C}-14$, the NRG issued Generic Letter 81-14 to all operating PWK licensees, "Seismic Qualification of AFW Systems" dated February 10, 1981.2 This letter requested that each licensee (1) conduct a walkdown of nonseismically-qual ified portions of the AFW system and identify deficiencies amenable to simple actions to improve seismic resistance and (2) provide design information regarding their specific AFW system seismic capabilities to facilitate NRC backfit decisions.

The licensee of Arkansas Nuclear One, Unit 1, responded by letter on August 7, 1981.3 The licensee's response was not complete and a Request for Additional Information (RAI) was issued by the NRC, dated April 2, 1982.4 The licensee replied with a supplemental letter dated May $27,1982.5$

This report is a technical evaluation based on the information from the licensee's responses to GL $81-14$, including reconmendations for additional analysis and/or upgrading modification of this plant's AFW system.

\section{EVALUATION}

Information provided in the licensee's responses include:

- Specification of the overall seismic capability of the AFW system.

- Identification of the AFW system components that are currently, nonseismically qualified for a SSE.

- Description of the AFW systen boundary.

- Status of compliance with seismic related NRC bulletins and informetion notices.

- Identification of areas of modificatiou/upgrade and proposed areas and schedules for modification/upgrade after the next refueling outage.

- Description of methodologies and acceptance criteria for seismic design of the AFW system that was to be determined by the licensee to be seismically qualified to a SSE level.

We have reviewed the licensee's responses, and a point-by-point evaluation of the 1 icensee's responses against the Generic Letter's requirements as shown below. 


\subsection{SEISMIC CAPABILITY OF THE AFW SYSTEM}

Except for those items identified in the following, the AFW system has been designed, constructed, and maintained to withstand a SEE utilizing methods and acceptance criteria consistent with that applicable to other safety-related systems in the plant. Presently, those items identified by the licensee as not being fully seismically qualified are evaluated below.

- $\frac{\text { Pumps/Motors }}{\text { - }}$
- $\frac{\text { Piping }}{\text { Palves/Actuators }}$
$\frac{\text { Water Sourclies }}{\text { Initiation/Control Systems }}$

- Structures*
None

None

None

None

None

The licensee atated that some components of the initiation/control systems are currently nonseismically qualified and they will be upgraded after the next refueling outage. Because the 1 icensee did not discuss their specific seismic capacity, we judge that the current seismic capacity of the initiation/control system is less than OBE; but it will be at the SSE level when the licensee's upgrade is completed. None

Based on our evaluation described above, those areas of the AFW system judged not to possess a SSE seismic capability are identified below. We conclude that the AFW system will possess a SSE level of seismic cafability on the completion of the AFW upgrade project.

\begin{tabular}{|c|c|c|}
\hline & Purps/Motors & None \\
\hline & Piping & None \\
\hline & Valves/Actuators & None \\
\hline & Power Supplies & None \\
\hline & Water Source (s) & None \\
\hline & Initiation/Control Systems & None* \\
\hline & Structures & None \\
\hline
\end{tabular}

Based on the above evaluation, we conclude that the AFW system will possess a SSE level of seismic capability upon completion of the AFW upgrade project.

Because the primary water source and supply path is seismically qualified, switchover to a secondary water source is not involved. Additionally, information regarding the seismic capability of any alternate decay-heat removal system is not required vecause the AFW system will have a SSE level of seismic capatility.

* Not fully qualified, but currently being investigated. 
In regard to the AFW system boundary, the licensee considered only those portions of piping up to and including a single valve that is normally closed or capable of remote closure. Therefore, the AFW system boundary does not fully conform to the definition specified in GL 81-14. Since the licensee's response did not include any discussion on this deviation, we feel that it needs to be evaluated further by the NRC.

The licensee stated that the AFW system was included within the scope of the seismic related NRC bulletins: 79-02, 79-04, 79-07, 79-14, 80-11, and IE Information Notice 80-21.

\subsection{WALKDOWN OF NONSE ISMICALLY-QUALIFIED PORTION OF THE AFW SISTEM}

A walkdown of the nonseismically-qualified portion of the initial/control systems is requiled. The licensee's responses did not report any walkdown results, but indicated that they are continuing their investigation into the issues of seismic qualification by performing walkdowns, documentation reviews, and analyses, as appropriate.

\subsection{ADDITIONAL INFORMATION}

The licensee's responses provided a description of the methodologies, loading combinations, and acceptance criteria that were used in the design of the seiemically-qualified portions of the AFW system.

\section{CONCLUSIONS}

The information contained in the licensee's responses to GL $81-14$ is complete. The licensee did not report any results for a walkdwon of the nonseismically-qualified areas of the AFW system. However, the licensee indicated that they were continuing the investigation into seismic

qualification by performing walkdowns as well as other means. It is also noted that the licensee's AFW system bout-dary does not fully conform to the definition as specified in GL $81-14$.

Based on the submitted information, we conclude that the AFW system at Arkansas Nuclear One, Unit 1 , with exception of the boundary question, presently provides a reasonable assurance to perform the safety-related function following the occurrance of a SSE. We recommend that no further action be initiated regarding modification and/or upgrading of the AFW system of this plant under NRC Multiplant Action C-14.

\section{REFERENCES}

1. D. G. Eigenhut, "bultiplant Action Plan C-14; Seismic Qualification of Auxiliary Feedwater System," U. S. Nuclear Regulatory Commission, memorandum to H. R. Denton (February 20, 1981).

2. U. S. Nuclear Regulatory Commission, Generic Letter to all operating pressurized water reactor licensees, "Seismic Qualification of Auxiliary Feedwater System," (February 10, 1981). 
5. D. C. Trimble, Arkensas Power and Light Company, letter to D. G. Eisenhut of the U. S. Nuclea: Regulatory Commission (August 7, 19B1).

4. J. F. Stolz, U. S. Nuclear Regulatory Comission, lecter to the Arkansas Power and Light Company, "Request for Additional Information on Seismic Qualification of the Auxiliary Feedwater System, Arkansas Nuclear One:, Unit 1" (April 2, 1982).

5. J. R. Marshail, Arkansas Power and Light Company, letter to J. F. Stolz, U. S. Nuclear Regulatory Commission (Hay 27, 1982). 


\section{SEISMIC QUALIFICAT ION OF AUXILIARY FEEDWATER SYSTEM TECHNICAL EVALUATION REPCRT}

AKKANSAS NUCLEAR ONE: UNIT 2

\section{INTRODUCT ION}

since the accident at Three Mile Island Nuclear Station, considerable attention has been focused on the capability of nuclear power plants to reliably remove decay heat. The subject of this evaluation is the NRC Multiplant Action Plan C-14, "Seismic Qualification of AFW Systems."I

To implement the first phase of $\mathrm{C}-14$, the NRC issued Generic Letter 81-14 to all operating PWR licensees, "Seismic Qualification of AFW Systems" dated February 10, 1981.2 This letter requested that each licensee (1) conduct a valkdown of nonseismically-qualified portions of the AFW system and identify deficiencies amenable tu simple actions to improve seismic resistance and (2) provide design information regarding their specific AFW aystem seismic capabilities to facilitate NRC backfit decisions.

The 1icensee of Arkansas Nuclear One: Unit 2, responded with a letter dated August 7, 1981.3 The licensee's response was found not to be complete and a Request for Additional Information (RAI) was issued by the NCR, dated April 29, 1982.4 The licensee provided a supplemental response in a letter dated May 27, 1982.5

This report is a technical evaluation based on the information from the 1icensee's responses to GL 81-14, including recommendations for additional analysis and/or upgrading modification of this plant's AFW system.

\section{EVALUAT ION}

Information provided in the licensee's responses include:

- Specification of the overall seiswic capability of the AFW system.

- Description of methodologies and acceptance criteria for seismic design of the AFW system, which is determined to be seismically qualified to the SSE level by the licensee.

- Description of the AFW system boundary.

- Status of compliance with saismic related NfC Bulletin's a-d Information Notices.

We have reviewed the licensee's responses, and a point-by-point evaluation of licensee's responses against the Generic Letter's requirements as shown below. 


\subsection{SEISMIC CAPABILITY OF THE AFW SYSTEM}

The AFW system has been designed, constructed, and maintained to withstand a SSE utilizing methods and acceptance criteria consiscent with that applicable to other safety-related systems in the plant. All areas of the AFW system, i.e., pump/motors, piping, valves/actuators, power supplies, water source, instrument/control systems, and structures supporting and housing the AFW system, are seismically qualified to the SSE level.

The licensee provided a description of the methodologies and acceptance criteria used for seismic qualification of the AFW system, and referred to the applicable sections of the FSAR. The description includes seismic analysis methods, seimic input, load combinations, allowable stresses, qualification testing, and engineering evaluations performed.

Because the primary water source and supply path is seismically qualified, switchover to a secondary water source is not involved. Additional information regarding the seismic capability of any alternate decay heat removal system is not required because the AFW system currently has a SSE level of seismic capability.

Regarding the AFW system boundary, the licensee did not clarify whether the boundary fully conforms to the definitions given in the Generic letter 81-14 with respect to branch piping being qualified out to the second valve normally closed or capable of automatic closure when function is required or to a point of three orthogoal restraints.

The licensee stated that the AFW system was included wit..in the scope of the seismic related NRC Bulletins 79-02, 79-04, 79-07, 79-14, 80-11, and IE Information Notice $80-21.2$

\subsection{WALKDOWN OF NONSE ISMICALLY-QUALIFIED PORTIONS OF THE AFW SYSTEM}

A walkdown is not required because no lack of seismic qualification of the AFW syster is indicated.

\section{CONCLUSIONS}

The information contained in licensee's responses to Generic Letter 81-14 is complete except that it did nmot clarify whether the AFW system boundary fully conform to the definitions of Generic Letter 81-14.

Based on the submitted information, we conclude that the AFW system is fully seismically qualified and is able to provide the safety related function following a SSE assuming that the AFW system boundary fully conform to the boundary definitions specified in GL $81-14$. Therefore, we recommend that no turther action be initiated regarding upgrading of the AFW systems of this plant under NRC Multiplant Action Plant C-14. 


\section{REFERENCES}

1. D. G. Eisenhut, "Multiplant Action Plan C-14; Seismic Qualification of Auxiliary Feedwater System," U. S. Nuclear Regulatory Comissinn, memorandum to H. K. Denton (February 20, 1981).

2. U. S. Nuclear Regulatory Commission, Generic Letter to all operating pressurized water reactor licensees, "Seismic Qualification of Auxiliary Feedwater System," (February 10, 1981).

3. D. C. Trimble, Arkansas Power and Light Company, letter to D. G. Eisenhut of U. S. Nuclear Regulatory Comission (August 7, 1981).

4. USNRC, letter to Arkansas Power and Light Company, "Request for Additional Information on Seismic Qualification of the Auxiliary Feedwater System, Arkansas Nuclear One, Unit 2" (April 29, 1982).

5. J. R, Marshall, Arkansas Power and Light Company, letter to R. A. Clark of U. S. Nuclear Regulatory Commission (May 27, 1982). 


\title{
SE ISMIC QUALIFICATION OF AUXILIARY FEEDWATER SYSTEM \\ TECHNICAL EVALUATION REPORT
}

\author{
BEAVER VALLEY: UNIT 1
}

\section{INTRODUCTION}

Since the accident at Three Mile Is land Nuclear Station, considerable attention has been focused on the capability of nuclear power plants to reliably remove decay heat. The subject of this evaluation is the NRC Multiplant Action Plan C-14, "Seismic qualification of AFW Systems."l

To implement the first phase of C-14, the NRC issued Generic Letter 81-14 to all operating PWR licensees, "Seismic Qualification of AFW Systems" dated February 10, 1981,2 This letter requested that each licensee (1) conouct a walkdown of nonseismically-qualified portions of the AFW system and identify deficiencies amenable to simple actions to improve seismic resistance and (2) provide design information regarding their specific AFW system seismic capabilities to facilitate NRC backfit decisions.

The licensee of Beaver Valley, Unit 1, responded with a letter dated August 5, 1981,3 and provided a supplenental response in a letter dated November $10,1981.4$

This report is a technical evaluation based on the information from the licensee's responses to GL $81-14$, including recomendations for additional analysis and/or upgrading modification of this plant's AFW systers.

\section{EVALUATION}

Information provided in the licensee's responses include:

- Specification of the overall seismic capability of the AFW system.

- Description of methodologies and acceptance criteria for seismic design of the AFH system, which is determined to be seismically qualified to the SSE level by the licensee.

- Description of the AFW system boundary.

- Stacus of compliance with seiamic related NRC Bulletins and In formation Notices.

We have reviewed the licensee's responses, and a point-by-point evaluation of the licensee's responses against the Ceneric Letter's requirements as shown below.

\subsection{SEISMIC CAPABILITY OF THE AFW SYSTEM}

The AFW system has been designed, constructed, and maintained to withotand a SSE utilizing methods and acceptance criteria consistent with that applicable to other safety-related systems in the plant. All areas of the AFW system (i.e., pumps/motors, piping, valves/actuators, power supplies, 
water source, instrumentation/control systems, and structures supporting and housing the AFW system) are seismically qualified to the SSE level.

The licensee provided a description of the methodologias and acceptance criteria used for seismic qualification of the AFW system, and referred to the applicable sections of the FSAR. The description includes seismic analysis methods, seismic input, load combinations, allowable stresses, qualification testing, and engineering evaluations performed.

Because the primary water source and supply path is seismically qualified, switchover to a secondary water source is not involved.

Information regarding the seismic capability of any alternate decay heat removal system is not required because the AFW system is fully seismically qualified.

Regarding the AFW system boundary, the licensee stated that it fully conforms to the definitions of the Generic Letter 81-14.

The licensee stated that the AFW system was included within the scope of the seismic related NRC Bulletins 79-02, 79-04,79-07,79-14, 80-11, and IE Information Notice $80-21$.

\subsection{WALKDOWN OF NONSEISMICALLY-QUALIFIED PORTION OF THE AFW SYSTEM}

A walkdown is not required because no lack of seismic qualification of the AFW system is indicated.

\section{CONCLUSIONS}

The information contained in licensee's responses to Generic Letter 81-14 is complete. The licensee stated that the AFW system boundary fully conforms to the definitions of Generic Letter 81-14.

Based on the submitted information, we conclude that the AFW system is fully seismically qualified and is able to provide the safety related function following a SSE. Therefore, we recommend that no further action be initiated regarding upgrading of the AFW system of this plant under NRC Multiplant Action Plan C-14.

\section{REFERENCES}

1. b. G. Eisenhut, "Multiplant Action Plan C-14; Seismic Qualification of Auxiliary Feedwater Syatem," U. S. Nuclear Regulatory Commission, memorandum to H. R. Denton (February 20, 1981).

2. U. S. Nuclear Regulatory Commission, Generic Letter to all operating pressurized water reactor licensees, "Seismic Qualification of Auxiliary Feedwater System," (February 10, 1981). 
3. J. J. Carey, Duquesne Light, letter to S. A. Varga of U. S. Nuclear Regulatory Commission (August 5, 1981).

4. J. J. Carey, Juquesne Light, letter to S. A. Varga of U. S. Nuclear Regulatory Commission (November 15, 1981). 


\title{
SE ISMIC QUALIFICATION OF AUXILIARY FEEDWATER SYSTEM TECHNICAL EVALUATION REPORT
}

\author{
CALVERT CLIFFS NUCLEAR PLANT: UNITS 1 AND 2
}

\section{INTRUDUCTION}

Since the accident at Three Mile Island Nuclear Station, considerable attention has been focused on the capability of nuclear power plants to reliably remove decay heat. The subject of this evaluation is the NRC Multiplant Action Plan C-14, "Seismic Qualification of AFW Systems."I

To implement the first phase of $\mathrm{C}-14$, the NRC issued Generic Letter 81-14 to all operating PWR licensees, "Seismic Qualification of AFW Systems" dated February 10, 1981.2 This letter requested that each licensee (1) conduct a walkdown of nonseismically-qualified portions of $t^{\xi}$ e AFW system and identify deficiencies amenable to simple actions to improve seismic resistance and (2) provide design information regarding their specific AFW system seismic capabilities to facilitate NRC backfit decisions.

The licensee of Calvert Cliffs Nuclear Plant, Units 1 and 2 , responded with a letter dated June $30,1981.3$ The licensee's response was found not to be complete and a Request for Additional Information was issued by the NRC, daced

January 6, 1982.4 The licensee provided a supplemental response in a letter dated February $25,1982.5$

This report is a technical evaluation based on the information from the licensee's responses to GL $81-14$, including recomendations for additional analysis and/or upgrading modification of this plant's AlW system.

\section{EVALUAT ION}

Information provided in the licensse's responses include:

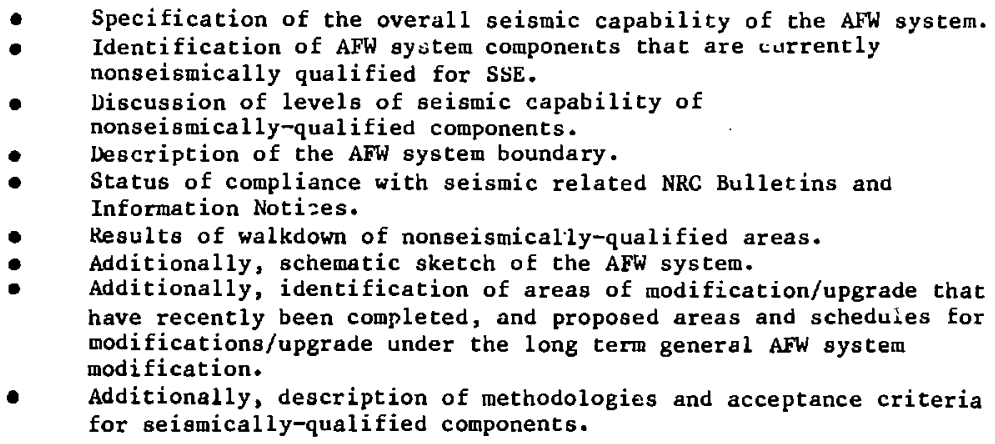


We have reviewed the licensee's responses, and a point-by-point evaluation of the licensee's responses against the Generic Letter's requirements as shown below.

\subsection{SELSMIC CAPABILITY OF THE AFW SYSTEM}

Except for those items identified in the following, the AFW system has been designed, constructed, and maintained to withstand a SSE utilizing methods and acceptance criteria consistent with that Esplicable to other safety-related systems in the plant. Presently, those items identified by the licensee as not being fully seismically qualified are evaluated below.

- Pumps/Motors

- Piping
Pump turbine and associated trip/throttle valve assembly. However, the licensee has stated that the same model in aother nuclear plant having the similar configuration was qualified for seismic load exceeding that required for Calvert Cliffs Plant. Therefore, we believe that the turbine ind associated trip/throttle valve assembly possess seismic capability that will survive a SSE.

(a) A portion of the AFW pump minimum flow recirculation piping. The recirculation line, is routed through the nonseismic Class I turbine building, but the minimum flow requirement is not an important safety parameter with respect to other one-time system functions under emergency conditions and failure of this portion downstream of the first restriction orifice will not significantly affect the $A F W$ system function. (b) The $10^{\prime \prime}$ exhaust 1 ine from each AFW pump turbine. It is routed through the seismic class I AFW pump room and the nonseismic Class I turbine building. However, we cosidered it to be acceptable because the turbine building portion of the line is properly supported, and because failure or rupture of the line would not significantly affect the AFW pump turbine operation. (c) The chemical addition piping which ties into the common pump suction piping in the AFW pump room. The line is nonseismic Class I and the chemical addition equipment is located in the turbine building. However, this line can be isolated 


\section{Valves/Actuators}

Power Supplies

Water source(s)

Initiation/Control Systems

Structures

from AFW system by an existing manual value located in the pump room. The licensee noted that the portion of piping between the valve and the AFW system is very small (two welds). The licensee also plans to cut and cap the additional cherical addition line installed by each AFW containment penetration room of Unit 1 because these lines are not presently in use.

All manual valves except for the penetration and condensate storage tank No. 12 discharge valves, These manual valves were purchased without seismic qualification, and were installed in seismic lines and analyzed with the system. The licensee noted that these valves are similar in material and construction to others that have been seismically qualified. In the absence of any information on the specific level of seismic capability of the other seismically-qualified valves, we believe the valves at Calvert cliffs plants probably possess a seismic capability that will survive an operating basis earthquake (OBE). All circuit-carrying conduits. They were installed according to standard seismic installation details and guidelines, and will be upgraded to Class $1 \mathrm{E}$ during the general AFW system modifications. None

(a) The Burbon tube type pressure indicators and the remote turbine trip hand-switches. They are being upgraded under the general AFW modifj.cation and will meet IE 79-01B and NUREG-0588 intent. (b) The instrument air source for AFW pump turbine throttle. Howerer, it is not a safety related item and when it fails, the throttle valve will be in a fully open position.

The turbine building. However, this does not present seismic related concerns because the curbine building houses and supperts only components such as the recirculation line, exhaust piping, and chemical addition line, which are not essential to safety function of the AFW system. 
Based on our evtluation described above, those areas of the AFW system judged not to possess a SSE seismic capability are identified below.

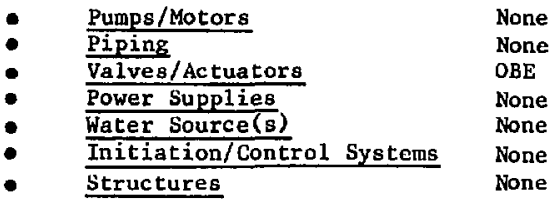

In sumary, our evaluation indicates that the licensee's AFW system does not possess an overall seismic capability that can survive a SSE.

Because the primary water source and supply path is seismically qualified, switchover to a secondary water source is not involved.

Seismic qualification information for any alternate decay heat removal system was not provided in the licensee's responses. This information was requested by GL $81-14$ if substantial lack of seismic qualification is indicated for the AFW system. The licensee stated that its AFW system exhibit a high degree of inherent seismic resistance. Based on the information provided by the licensee we did not find that the licensee's AFW system has a SSE capability. For the purpose of removing decay heat following a SSE, the licensee needs to either re-analyze and/or modify its AFW system or provide an alternate decay heat removal system seismically qualified to the SSE level and appropriate operating procedures.

Regarding the AFW system boundary, the licensee identified that: (1) the pump turbine exhaust piping has no isolation valves, but we do not consider the turbine exhaust piping to be part of the boundary of the AFW system. (2) the recirculation piping has two valves that are required to be open during operation of the AFW pumps and cannot be normally or automatically shut. The recirculation line, however, is seismically mounted to a paint downstream of the flow restriction orifices. Should the pipe break of downstream of these orifices, no problews would result because the increase in flow through the line would be minimal compared with that available to the pump suction. Therefore, we determine that the AFW system boundary conforms to that required by the Generic Letter.

The licensee stated that the AFW system was included within the scope of seismic related Bulletins 79-02,79-04,79-07,79-14,80-11, and IE Information Notice $80-21$.

\subsection{WALKJOWN OF NONSEISMI CALLY-QUALIEIED PORTIONS OF THE AFW SYSTEM}

The licensee performed a walkdown of the as-built configurations of those nonseismically-qualified items for which there are no plans to upgrade. Areas where a walkdown was not performed include the recirculation piping, pump turbine exhaust piping, all nonseismically-qualified manual valves, and instrument air source. We conclude that the walkdown performed by the licensee is not complete. 
The licensee provided a schematic sketch of the AFW system including the water source, heat sink, suction and discharge piping, major mechanical equipment, and structures housing and supporTing AFW system itens.

Additionally, licensee's responses provided a description of the methodologies, loading combinations, and acceptance criteria that were used in the design of the seismic Class I components of the AFW system.

The licensee also provided the foliowing information on completed and scheduled modification/upgrade related to, but not as a direct result of, GL 81-14:

- All electric power supplies have been u, sgaded to class IE during
recent plant modifications.
Each AFW system has been modified to include a safety-related
automatic start system in accordance with NUREg 0578 and 6737 .
The general AFW system modifications are scheduled to be completed
by the fall 1982 for Unit 2 and the fall 1983 for Unit 1 . For
Unit 2, however, the completion date will be delayed until the
spring of 1984, if equipment deliveries are not met. These
modifications include: upgrading the pump turbine and associated
trip/throttle valve assemblies, upgrading the chemical addition
line to seigmic Gategory I, cutting and capping the chemical
addition lines installed by the Unit 1 containment penetration
rooms, and upgrading all circuit carrying conduits and
initiation/controls to class IE to meet the requirements of IE
79-01B and NuRE 0588.
The upgraded chemical addition line seismic supports will be
installed by January 1 , 1983 .

\section{CONCLUSIONS}

The information contained in licensee's responses to GL 81-14 is complete, The licensee conducted a partial walkdown in that it encompassed anly those nonseismically-qualified areas which the licensee has no plan to upgrade. The walkdown did not find seismic related deficiencies. Based on submitted information, we conclude that the AFW system does not provide a reasonable assurance to perform its required safety function following a SSE, because the nonseismically-qualified valves are judged to have only an $O B E$ level resistance. Since the licensee does not presently plan ta upgrade these valves, we recommend that the NRC consider requiring the licensee to provide a re-analysis and/or modification to acquire a SSE capacity for these valves.

\section{REFERENCES}

1. D. G. Eisenhut, "Multiplant Action Plan C-14; Seismic Qualification of Auxiliary Feedwater system," U. S. Nuclear Regulatory Commission, memorandum to H. R Denton (Eebruary 20, 1981). 
2. U. S. Nuclear Regulatory Commission, Generic Letter to all operating pressurized water reactor licensees, "Seismic Qualification of Auxiliary Feedwater System," (February 10, 1981).

3. A. E. Lundvall, Jr., Baltimore Gas \& Electric, letter to R. A. Clark of U. S. Nuclear Regulatory Commission (June 30, 1981).

4 K. A. Clark, U. S. Nuclear Regulatory Commission, letter to A. E. Lundvall of Baltinore Gas \& Electric, "Request for Additional Information on Seismic Qualification of the Auxiliary Feedwater System, Calvert Cliffs Nuclear Plants, Units 1 and 2" (January 6, 1982).

5. A. E. Lundvall, Jr., Baltimore Gas \& Electric, letter to R. A. Clark of U. S. Nuclear Regulatory Commission (February 25, 1982). 


\section{SEISMIC QUALIFICATION OF AUXILIARY FEEDWATER SYSTEM TECHNICAL EVALUATION REPORT}

DONALD C. COOK NUCLEAR PLANT: UNITS 1 AND 2

\section{INTRUDUCTION}

Since the accident at Three Mile Island Nuclear Station, considerable attention has been focused on the capability of nuclear power plants to reliably remove decay heat. The subject of this evaluation is the NRC Multiplant Action Plan C-14, "Seismic Qualification of AFW Systems."1

To implement the first phase of C-14, the NRC issued Generic Letter 81-14 to all operating PUR lizensees, "Seismic Qualification of AFW systems" dated February $10,198 \mathrm{i} .2$ This letter requested that each licensee ( 1 ) conduct a walkdown of nonseismicaily-qualified portions of the AFW system and identify deficiencies amenable to simple actions to improve seismic resistance and (2) provide design information regarding their specific AEW system seismic capabilities to facilitate NRC backfit decisions.

The licensee of D. C. Cook Nuclear Plant, Units 1 and 2, responded with a letter dated August $28,1981.3^{3}$ The licensee's response was found not to be complete and a Request for Additional Information (RAI) was issued by tha NRC, daced April 5, 1982.4 The licensee provided a supplemental response in a letter dated June $15,1982.5$

This report is a technical evaluation based on the information from the licensee's responses to GL $81-14$, including cecommendations for additional analysis and/or upgrading modification of. .s plant's AFW system.

\section{EVALUATION}

Intormation frovided in the licensee's responses include:

- Specification of the overall seismic capability of the AFW system.

- Identification of AFW syatem components that are currently nonseismically zualified for SSE.

- Discussion of levels of seismic capability of

nonseismically-qualified components.

Description of the AFW system boundary.

- Descr

- Status of compliance with seismic related NRC Bulletins and Information Notices.

- Results of partial walkdown of the nonseismically-qualified piping, and $s$ chedule for the ongoing field verification of the remaining ronseismically piping.

- Additionally, diagrams of the AFW system.

- Additionally, description of methodologies and acceptance criteria for seismically-qualified components. 
We have reviewed the licensee's responses, and a point-by-point evaluation of the licensee's responses against the Generic Letter's requirements as shown below.

\subsection{SEISMIC CAPABILITY OF THE AFW SYSTEM}

Except for those items identified in the following, the AFW system has been designed, constructed, and maintained to withstand a SSE utilizing methods and acceptance criteria consistent with that applicable to other safety-related systems in the plant. Presently, those items identified by the licensee as not being fully seismically qualified are evaluated be?ow.

\section{- $\quad$ Pumps/Mators}

Valves/Actuators Power Supplies
None

(a) The condensate storage tank associated piping was designed to seismic Class II criteria. The condensate storage tank itsel $E$ is seisric Class II and was designed to the $O B E$ level. However, a seismic class I secondary wacer source, i.e., the essential service water system, exists at the plant. Therefore, we judge that this piping is not essential to the safecy related function of the AFW system. (b) ine main feedwater piping upstream from the check valve to the motor operated valve is classified as seismic class III, but was designed to the USAS $B$ $31.1,1967$ edition and to withst.and the OBE. Additionally, this segment of piping is part of licensee's ASME B\&PV Code, Section XI, Code Class 2 Surveilance Program. Since the portion of the main feedwater piping discussed in (b) above is required to accomplish the $A F W$ system function, we conclude that the AFW system piping possesses a seismic capability of the $O B E$ level although the $A F W$ system piping itself is seismically qualified to the SSE level. None

Licensee indicated that the $4 \mathrm{KV}$ switchgear cabinets ( $T 1 l_{A}$ to $\mathrm{D}$ ), the $600 \mathrm{~V}$ switchgear cabinets $11 \mathrm{~A}$ to $\mathrm{D}$, and the reactor trip and bypass breaker cabinets were found to be inadequately installed against overturning during the SSE. However, the permanent modif:cation of the anchorage has been completed by August 28, 1981, and we therefore 


\section{- Water Source(s)}

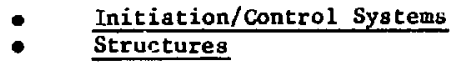

conclude that the power supplies now possess * seisnic capability that will withatand a SSE.

The primary water source, i.e., the condensate storage tank, is seismic Class II and was designed to the OBE level. The secondary water source is the seismic class I essential service water syatem. The procedure to switch the AFW pump suction to the essential service water system existc and is in place at the plant. Details of the procedure was described in licensee's letter to NRC dated March 28, 1980, No. AEP:NRC:0307A, and the procedure was accepted by NRC via S. Varga's letter of October 6, 1980 to the licensee. We conclude that the water sources possess a SSE level of seismic capacity.

None

On the suction side, close to the condensate storage tank, the first valve and about three feet of piping are seismic class I but do not have a seismic Class I enclosure. The enclosure provided is a fabricated sheet metal enclosure and the licensee did not discuss its seismic capacity. We judge that the structures possess an OBE level of overall seismic capacity". However, it is not clear to us whether the portion of the piping protected by the nonseismically qualified enclosure is part of the primary water source and path. If this is the case, the failure of the enclosure should not affect the safety related function of the $\mathrm{AFW}$ system.

Based on our evaluation described above, those areas of the AEW system judged not to possess a SSE seismic capability are identified below.

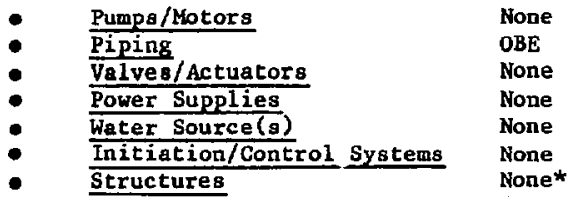

* The level becomes OBE if the segment of piping protected by the nonseismically-qualified enclosure structure is not part of the primary water source and path. 
In sumary, our evaluation indicated that the majority of the AFW system at D. C. Cook Nuclear P1ant, Units 1 and 2, presently possesses a level of seismic capability that can withstand a SSE with the exception of a portion of the main feedwater piping connected to the AFW system and, possibly, one piping enclosure structure as discussed above.

The primary water source and supply path is not seismically qualified and, therefore, switchover to the seismically-qualified secondary water source and supply path, i.e., the essential service water system, is required. The switchover procedure is available at the plant and was accepted by the NRC.

The seismic qualification information for any alternate decas heat removal system was not provided in the licensee's responses. This information was requested by the Generic Letter if substantial lack of seismic qualification is indicated for the AFW system. Based on the submitted information from licensee's responses, we find that the AFW system is not fully capable of performing the required safety-related function following the occurrence of a SSE. Therefore, we conclude that the licensee is required to either provide the information on seismic qualification of any alternate decay heat removal system or reanalyze/upgrade the exiscing AFW system to withstand the SSE.

Regarding the AFW system boundary, the licensee stated that the boundary of the AFW system as currently evaluated coincide with the boundary definition specified in GL 81-14. The licensee also statrad that all work applicable to the AFW system for IE Bulletins 79-02 and 79-07 is completed; work applicable to the AFW system for IE Bulletins 79-14 and 80-11 is presently being completed; and IE Information Notice 80-21 is currently under review. The licensee also indicated that IE Bulletin 79-04 is not applicable to the AFW system re-evaluation because IE Bulletin 79-04 was issued in reference to incorrect weights for Velan swing check valves and there are no Velan valves in the AFW system for D. C. Cook Plant. He conclude that the AFW system is included within the scope of the applicable seismic related NRC Bulletins and Information Notices.

\subsection{WALKDOWN OF NONSEISMICALLY QUALIFIED PORTIONS OF THE AFW SYSTEM}

A walkdown of the nonseismically-qualified portion of the AFW system is required. The licensee indicated that walkdown has been conducted for the nonseismically-qualified piping connected to the condensate storage tanks and no deficiencies were identified. The licensee also indicated that efforts are underway to verify in the field the portion of the seismic class III main feedwater piping upstrieam from the check valve to the motor-operated valve. As part of this effort; the licensee identified one valve control cabinet missing the anchorage'shown on the design drawings. This deficiency was immediately repaired and reported to the NRC, Region III. The licensee will submit the results of the fieldwalk once it is completed, currenty scheduled to be during the next refueling outage.

\subsection{ADDITIONAL INFORMATION}

The licensee provided a feedwater diagram and main stream diagram which illustrace the boundary of the AFW system. Additionally, licensee's responses provided a description of the methodologies, loading combinations and acceptance criteria that were used in the design of the seismically-qualified portion of the AFW system. 


\section{CONCLUSIONS}

The information contained in licensee's responses to GL 81-14 is complete. The licensee has conducted a partial walkdown for the nonseismically-qualified piping and is currently performing another field walkdown of the remaining nonseismically-qualified piping acheduled to be completed during the next refueling outage.

Based on the submitted information, we judge that the AFW system at D. C. Cook Nuclear Plant, with the exception of a portion of the main feedwater piping connected to the AFW system and one enclosure structure, presently provides a reasonable asourance to perform ito required safety functions following a SSE. In conclusion, we recommend that the NRC consider requiring the licensee to reanalyze and/or upgrade the AFW gystem to assure an overall geismic capability of the SSE level.

\section{REFERENCES}

1. D. G. Eisenhut, "Multiplant Action Plan C-14; Seismic Qualification of Auxiliary Feedwater System," U. S. Nuclear Regulatory Commission, memorandum to H. R. Denton (February 20, 1981).

2. U. S. Nuclear Regulatory Commission, Generic Letter to all operating pressurized water reactor licensees, "Seismic Qualification of Auxiliary Feedwater System," (February 10, 1981).

3. R. S. Hunter, Indiana \& Michigan Electric Oc., letter to H. R. Denton of U. S. Nuclear Regulatory Comnission (August 28, 1981).

4. S. A. Varga, U. S. Nuclear Regulatory Commission, letter to R. S. Hunter of Indiana \& Michigan Electric Co., "Request for Additional Information on Seismic Qualification of the Auxiliary Feedwater System, Donald C. Cook Nuclear Plant, Units 1 and 2" (April 5, 1982).

5. k. S. Hunter, Indiana \& Michigan Electric Co., letter to H. R. Denton of U. S. Nuclear Regulatory Comnission (June 15, 1982). 


\section{SEISM ? QUALIFICATION OF AUXILIARY FEEDWATER SYSTEM TECHNICAL EVALUATION REPORT}

CRYSTAL RIVER NUCLEAR PLANT: UNIT 3

\section{INTRODUCTION}

Since the accident at Three Mile Island Nuclear Station, considerable attention has been focused on the capability of nuclear power plants to reliably remove decay heat. The subject of this evaluation is the NRC Multiplant Action Plan C-14, "Seismic Qualification of AFW Systems."l

To implement the first phase of $\mathrm{C}-14$, the NRC issued Generic Letter 81-14 to all operating PWR licengees, "Seismic Qualification of AFW Systems" dated February 10, 1981.2 This letter requested that each licensee (1) conduct a walkdown of nonseismically-qualified portions of the AFW syscem and identify deficiencies amenable to simple actions to iwprove seismic resistance and (2) provide design informatiou regarding their specific AFW system seismic capabilities to facilitate NRC backfit decisions.

The licensee of Crystal River Muclear Plant, Unit 3, respr, ded with a letter dated July $14,1981.3$ The licensee's response was incomplete and a Request for Additional Information (RAI) was issued by the NRC, dated January $7,1982.4$ The licensee provided a supplemental responses in letters dated February $26,1982^{5}$ and April 20, 1982.6

This report is a technical evaluation based on the information from the licensee's responses to GL $81-14$, including recomendations for additional analysis and/or upgrading modification of this plant's AFW system.

\section{EVALUATION}

Information provided in the licensee's responses include:

- Specification of the overall seismic capability of the AFW system.

- Identification of AFW system components that are currently nonseismically qualified for SSE.

- Discussion of levels of seismic capability of nonseismically-qualified components of the AFW system.

- Description of the AFW system boundary.

- Status of compliance with seismic related NRC Bulletins and Information Notices.

- Results of a walkdown of nonseismically-qualified areas.

- Additionally, a schematic sketch of the AFW system.

- Additionally, description of methodologies and acceptance criteria for seismically-qualified AFW system components.

- Additionally, results of walkdown of the seismicallymqualified AFW system areas.

We have reviewed the licensee's responses, and a point-by-point evaluation of the licensee's responses against the Generic Letter's requirements as shown below. 


\subsection{SEISMIC CAPABILITY OF THE AFW SYSTEM}

Except for those items identified in the following, the AFW system has been designed, conscructed, and maintained to withstand a SSE utilizing methods and acceptance criteria consistent with that applicable to other safety-related systems in the plant. Presently, those items identified by the licensee a not being fully seimmically qualified are evaluated below.

\begin{tabular}{ll}
- & $\frac{\text { Pumps/motors }}{\text { Piping }}$ \\
Valves/Actuators \\
\hline Power Supplies
\end{tabular}

Water Source (s) Initiation/Control systems

\author{
None \\ None \\ None \\ In Ref. 5, the licensee provided a \\ partial list that identifies the \\ trubine-building motor-control center \\ that supplies power to the individual \\ pump-discharge valve, condensate \\ storage-tank suction, and main \\ condenser suction valve. However, \\ chese valves are prepositioned to be \\ not required for actuation for $A F W$ \\ syatem operation and are only \\ required for maintenance or transfer \\ of suction supply from the condensate \\ storage tank to the nonqualified \\ backup condenser hotwell. We, \\ therefore, conclude that the \\ turbine-building motor-control center \\ is not essential to providing the \\ safecy function of the AFW system. \\ Later in Ref. 6 , the licensee \\ identified the remaining \\ nonseismically-qualified power supply \\ times, but did not evaluate their \\ seismic capability. However, the \\ licensee also stated that such power \\ supplies will be upgraded under their \\ overall AFW system upgrade project. \\ None \\ In Ref. 5 the licensee provided a \\ partial list that identifies (a) the \\ automatic actuation and control \\ system, and (b) several manual \\ control stations located on a section \\ of the main control board that was \\ not seismically qualified. However, \\ seisurcally-qualified manual flow \\ controls and circuits independent of \\ the nonnuclear instrumentation (NNI) \\ and integrated control system (ICS) \\ are provided on a qualified section \\ of the main control board, and hence \\ there is no seismic related concern. \\ Later in Ref. 6, the licensee \\ identified the remaining \\ nonseismically-qualified
}


initiation/control syutem components, but did not evaluate their seismic capability. However, the licensee also stated that initiation/control syetem will be upgraded under their general AFW upgrade project.

\section{- Structures}

None

Based on our evaluation described above, those areas of the AFW system judged not to possess a SSE seismic capability are identified below.

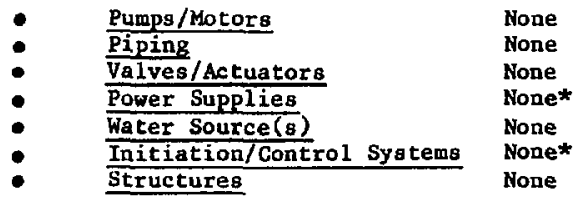

Based on the above evaluation, we conclude that the AFW aystem will possess a SSI level of seismic capability upon completion of the general upgrade project

Because the primary water source and supply path is seismically qualified, switchover to a secondary water source is not involved. Additionally, information regarding the seismic capability of any alternate decay-heat removal system is not required, because the AFW system will have a SSE level of seismic capability.

Regarding the AFW system boundary, with only one exception, all branch lines, which are not seismically qualified and are structurally coupled to the AFw system, have been analyzed out to a point of three orthogonal restraints, such that all transmitted seismic loads have been considered in the AFW aystem qualification. The one exception is the AFW steam-8upply drain-tank vene connection to the turbine exhaust line. This vent line is currently under review by the licensee.

The 1 icensee stated that the AFW was included within the scope of the seismic related NRC Bulletins: 79-02, 79-04, 79-07,79-14, 80-11 and IE Information Notice 80-2l.

\subsection{WALKDOWN OE NONSEISMICALLY-QUALIFIED PORTION OF THE AFW SYSTEM}

A walkdown of the nonseismically-qualified areas identified certain power supply items to be deficient. They include some inadequate cable tray supports at elevation $95 \mathrm{ft}$, a clamp missing from a cable tray support at elevation $119 \mathrm{ft}$, one loose hanger in the cable spreading room, and three loose item in the control-complex electrical support room. The licensee vill add steel angle braces, where necessary, replace the missing clamp, and tighten all loose items. Such corrective actions will be accomplished as part of the overall AFW system upgrade, which is acheduled concurrent with the Crystal River, Unit 3, refueling outage in the first half of 1983.

* Current seimic capability unknown, but will be upgraded. A-24 


\subsection{ADDIT IONAL INEORYATION}

The licensee provided a schematic sketch of the AFW oystem including the water source, heat aink, ouction and discharge 1 ines, major mechanical equipment, connected branch lines, and structures housing and supporting the AFW syotem.

The licensee also provided information on the methodologies and acceptance criteria that were used in the seismic design of the seismicallyqualified portions of the AFW system. In addition, they stated that, for floors having fundamental frequency less than $25 \mathrm{~Hz}$, the vertical seismic input was taken as two-thirds of the horizontal response apectrum for the respective evaluations.

Additionally, the licensee also performed walkdown of the seismically-qualified areas of the AFW system. Deficiencies were identified, corrective actions were proposed or are to be identified, and the schedule will be consistent with the overall AFW system upgrade as mentioned previously. The results of this walkdown are sumarized below:

- Piping - (a) A 4-in. stainless-steel line tied into the main steam line at valve (MSV-440) is supported only for dead weight. Besides, it is not properly attached to one support and a U-bolt is missing. (b) A 6-in. sump-discharge line routed above the AFW system suction line is supported for deadweight only by rod-type hangers. (c) The turbine-pump exhaust line appears to be supported for deadweight only by rod-type hangers. (d) The suction line from the condnesate hotwell is routed close to the AFW suction line from the condensate storage tank and there appears to be not enough clearance between the two lines. (e) A portion of the of the pump recirculation lines may not be adequately deaigned. (f) A line branch'ag off the trubine-pump exhaust line does not appear on drawings. (g) A laterai restraint, designed as a removable support to allow for future disassembly, will be added to one of the seal injection lines routed fro: the cop of the turbine-driven pump casing to valve (EFV-51). (h) One of the two ailencers hung over the suction line requires a more adequate support. (i) A clamp is mssing from the tubing run for pressure instrument ( $\mathrm{EF}-2-\mathrm{PI}$ ) for the pipe routing on the motor-driven AFW pump. It will be replaced.

- Primary Water Source and Supply Path - (a) Some new lines have been connected to the condensate storage tank that must be reviewed for sufficient seismic support. (b) The neutralizing tank appears too close to the condensate storage tank. A review of the seutralizing tank's foundation will be done ad, if necessary, a barrier between the two tanks may have to be added.

\section{CONCLUSIONS}

The information contained in Iicensee's responses to GL $81-14$ is insufficient for us to determine the present level of seismic capability of some areas of the existing AFW syatem. The licensee has stated that the AFW aystem will be upgraded under the general upgrade project. The walkdown conducted by the licensee identified some deficiencies and corrective actions A-25 
were planned with completion dates provided. Based on subnitted information, we concluded that the AFW system will possess a SSE level of seismic capability upon completion of the on-going general AFW system upgrade project. In conclusion, we recommend that no further action be intitated regarding reanalysis and/or upgrading of the AFW system of this plant under NRC Hultiplant Action C-14.

\section{REFERENCES}

1. D. G. Eisenhut, "Multiplant Action Plan C-14; Seismic Qualification of Auxiliary Feedwater Syotem," U. S. Nuclear Regulatory Commiosion, memorandum to H. R. Denton (February 20, 1981).

2. U. S. Nuclear Regulatory Commission, Generic Letter to all operating pressurized water reactor licensees, "Seismic Qualification of Auxiliary Feedwater System," (February 10, 1981).

3. P. Y. Baynard, Florida Power Corporation, letter to D. G. Eisenhut of U. S. Nuclear Regulatory Comrission (July 14, 1981).

4. J. F. Stolz, U. S. Nuclear Regulatory Comission, letter to D. G. Mardis of the Florida Power Corporation, "Requeat for Additional Information on Seismic Qualification of the Auxiliary Feedwater System, Grystal River Nuclear Plant, Unit 3," January 7, 1982.

5. D. G. Mardis, Florida Power Corporation, letter to J. F. Stolz of U. S. Nuclear Regulatory Commission, February 26, 1982.

6. D. G. Mardis, Florida Power Corporation, letter to J. F. Stolz of U. S. Nuclear Regulatory Commission, April 20, 1982. 


\section{SE ISMIC QUALIFICATION OF AUXILIARY FEEDWATER. SYSTEM TECHNICAL EVALUATION REPORT}

DAVIS-BESSE NUCLEAR PLANT: UNIT 1

\section{INTRODUCTION}

Since the accident at Three Mile Island Muclear Station, considerable attention has been focused on the capability of nuclear power plants to reliably remove decay heat. The subject of this evaluation is the NRC Multiplant Action Plan C-14, "Seismic qualification of AFW Syotema."1

To implement the first phase of C-14, the NRC issued Generic Letter 81-14 to all operating PWR 1icensees, "Seismic Qualification of AFW Systems" dated February 10,1981.2 This letter requested that each licensee (1) conduct a walkdown of nonseismically-qualified portions of the AWW system and identify deficiencies amenable to simple actions to improve seismic resistance and (2) provide design information regarding their specific AFW system seismic capabilities to facilitate NRC backfit decisions.

The licensee of Davis-Besse Nuclear Plant, Unit 1, responded with a letter dated July $15,1981.3$ The licensee's response was found not to be complete and a Request for Additional Information (RAI) was issued by the NRG, dated January $11,1982.4$ The licensee provided a supplemental response in a letter dated February 10, 1982.5

This report is a technical evaluation based on the information from the licensee 'a responses to GL $81-14$, including recomendations for additional analysis and/or upgrading modification of this plant's AFW system.

\section{EVALUATION}

Information provided in the licensee's responses include:

- Specification of the overall neismic capability of the AFW system.

- Identification of AFW system components that are currently nonseismically qualified for SSE.

- Summary of procedure for awitchover to the aecondary water source and supply path.

- Discussion of levels of seismic capability of nonseismically-qualified components.

- Description of the AFW system boundary.

- Status of compliance with seismic related NRC Bulletins and Information Notices.

- Additionally, a schematic oketch of the AFW system.

- Additionally, description of methodologies and acceptance criteria Eor eeiomically-qualified components.

Additionally, identification of areas of modification/upgrade that have been completed or are proposed along with a scheduie. 
We have reviewed the licensee's responses, and a point-by-point evaluation of the licensee's responses against the Generic Letter's requirements as shown below.

\subsection{SEISMIC GAPABILITY OF THE AEW SYSTEM}

Except for those items identified in the following, the AFW system has been designed, constructed, and maintained to withstand a SSE utilizing methods and acceptance criteria consistent with that applicable to other safety-related aystems in the plant. Presently, those items identified by the licensee as not being fully seismically qualified are evaluated below.

\section{- $\frac{\text { Pumps/motors }}{\text { Piping }}$}

- Valves/AcLuator

- Initiation/Control System

\section{None}

The auxiliary feedwater pump turbine (AFPT) pipe support. Under IE Bulletin 79-14, reanalysis of the stress associated with the AFPT has indicated an increase in the loads transmitted to the ARPT nozzles. The AFPT aupplier indicated that these loads would be acceptable for continued short term operations. Design modifications ot the AFPT pipe support have been completed and field installations are in progres. None

None

The condensate storage tank (CST) and the suction piping from the CST to its entrance to the auxiliary building. However, a secondary water source, i.e., the service water syotem (SWS) and oupply path is seismically qualified for SSE, and an automatic switchover is provided. All equipment required to effect the owitchover from the CST to SWS is Seismic Category I.

None

Structures supporting or housing safety related portion of the AFW system have been designed at Seibmic Category I except for 12 masonry walls/subwalls which did not meet the requirements of IE Bulletin 80-1 1 . The 12 masonry walle/subwalls are No8. $2297,3036,3167,3177,3187$, $3441,4016,4647,4796,4826,4886$, and 4896 . The modifications to walis 3447,4647 , and 4826 have been completed, and the modifications to the remaining nine walla are in progreas, to be completed by thanury, 1983 or sooner. 
Besed on our evaluation described above, those areas of the AFW system judged not to possess a SSE seimmic capability are identified below.

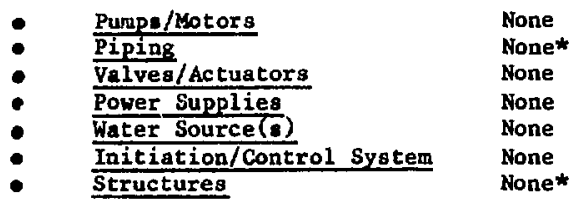

Based on the above evaluation, we conclude that the AFW system will possess a SSE level of seismic capability upon completion of the modifications to the AFPT pipe support and the nine concrete masonry walls/subwalls.

A seismic category I switchover from the primary source to a seismically-qualified secondary water source is provided. Information regarding the seismic capability of any alternate decay heat removal system is not required because the AFW system will have a SSE level of seismic capability upon completion of all proposed modifications of the presently nonseismically AFW system components.

Regarding the AFW system boundary, all branch lines except one have two valves that are normally closed or capable of automatic closure when safety function of the AFW system is required. The one exception is the alternatesupply-to-startup-feed-pump 1 ine, which has only one normally closed valve.

The AFW system was included within the scope of the seismic related NRC Bulletins 79-02, 79-04,79-07,79-14, 80-11 and IE Information Notice 80-21.

\subsection{WALKDOWN OF NONSEISMICALLY-QUALIFIED PORTION OF THE AEW SYSTEM}

A walkdown of the nonseismically-qualified areas of the AFW system has not been conducted $s$ ince they have been upgraded or are presently under modification.

\subsection{ADDITIONAL INFORMATION}

The licensee provided a schematic sketch of the AFW system including the water sources, heat sink, suction and discharge piping, major mechanical equipment, and structures supporting and housing the AFW syatem items.

Additionally, licensee's responses provided a description of the methodologies, loading combinations and acceptance criteria that wee used in the design of the aeismically-qualified portions of the AFW system.

The licensee also provided the following information on completed and ocheduled modification/upgrade related to, but not as a direct result of, GL 81-14:

* Note: Currently not fully seismically qualified, but are being upgraded. 
- AFPT pipe support design modificationa have been completed, and installation will be completed by the end of the 1982 refueling outage, under facility change request (FCR) 79-421.

- The AFPT exhaust piping has been redesigned and rerouted to provide separate exhaust from each of the turbines. This modification was completed under facility change request (FCR) 79-421.

- Modifications to concrete masonry walla/oubwalls No. 3447,4647 , and 4826 have been completed. Modifications to remaining nine masonry wall/oubwalls No. 2297, 3036, 3167, 3177, 3187, 4016, 4796, 4886 , and 4896 will be completed in January, 1983 or sooner as indicated in licensee's September 29, 1981 letter, Serial No. 1-217.

\section{CONCLUSIONS}

The information contained in licensee's responses to GL 81-14 is incomplete ince it does not provide sufficient information on the level of seismic capability of the currently nonseismically-qualified areas. The licensee did not conduct a walkdown of the nonseismically-qualified areas of the AFW system. However, these nonseismically-qualified areas have been, or are being, upgraded by the licensee. It is also noted that the licensee's AFW system boundary does not fully conform to the definition specified in

GL 81-14. Based on the submitted information, we conclude that the AFw system at Davis-Besse Unit 1 will be able to provide the oafety-related function following the occurrence of a SSE to assure safe shutdown of the plant upon completion of the scheduled AFW system upgrade. Therefore, we recommend that no further action be initiated regarding re-analysis and/or upgrading of the AEW system of this plant under NRC Multiplant Action C-14.

\section{REFERENCES}

1. D. G. Eisenhut, "Multiplant Action Plan C-14; Seismic Qualification of Auxiliary Feedwater System,"U. S. Nuclear Regulatory Comisaion, memorandum to H. R. Denton (February 20, 1981).

2. U. S. Nuclear Regulatory Commission, Generic Letter to all operating pressurized water reactor licensees, "Seismic Qualification of Auxiliary Feedwater System," (February 10, 1981).

3. K. P. Crouse, Toledo Edison Company, letter to D. G. Eisenhut of U. S. Nuclear Regulatory Comaission (July 15, 1981 ).

4. U. S. Nuclear Regulatory Commission, letter to R. P. Crouse, of Toledo Edison Co., "Request for Additional Information on Seismic Qualification of the Auxiliary Feedwater System, Davis-Besse Nuclear Power Station, Unit $1^{\text {" }}$ (January 11,1982 ).

5. R. P. Crouse, Toledo Edison Company, letter to D. G. Eisenhut of U. S. Nuclear Regulatory Comiseion (Pebruary 10, 1982). 


\section{SEISMIC QUALIFICATION OF AUXILIARY FEEDWACER SYSTEM TECHNICAL EVALUATION REPORT}

JOSEPH M. FARIEY: UNITS 1 AND 2

\section{INTRODUCTION}

Since the accident at Three Mile Island Nuclear Station, considerable ettention has been focused on the capability of nuclear power plants to reliably remove decay heat. The subject of this evaluation is the NRC tultiplant Action Plan C-14, "Seismic Qualification of AFW Systems."I

To implement the first phase of $\mathrm{C}-14$, the NRC issued Generic Letter 81-14 to all operating PWR licensees, "Seismic Qualification of AFW Systems" dated February 10, 1981.2 This letter requested that each licensee (1) conduct a walkdown of nonseismically-qualified portions of the AFW system and identify deficiencies amenable to simple actions to improve seismic resistance and (2) provide design information regarding their specific AFW system seismic capabilities to facilitate NRC backfit decisions.

The licensee of Jogeph $M$. Farley, Units 1 and 2, responded with a letter dated October 9, 1981.3 The licensee's reaponse was found not to be complete and a Request for Additional Information (RAI) was issued by the NRC, dated April 2, 1982.4 The licensee provided a supplemental response in a letter dated July 16,1982 .

This report is a technical evaluation based on the information from the licensee's responses to GL 81-14, including recomendations for additional analysis and/or upgrading modification of this plant's AFW system.

\section{EVALUATION}

Information provided in the 1 icensee's responses include:

- Specification of the overall seismic capability of the AFW system.

- Identification of currently a nseismically-qualified components of the AFW system.

- Description of the AFW system boundary.

- Status of compliance with seismic related NRC Fulletins and Information Notices.

- Additionally, description of methodologies and acceptance criteria. for the seismically-qualified components.

We have reviewed the licensee's responses, and a point-by-point evaluation of the licensee's responses against the Generic Letter's requirements as ahown below.

\subsection{SEISMIC CAPABILITY OF THE AFW SYSTEM}

Except for those items identified in the following, the AFW system has been designed, constructed, and maintained to withstand a SSE utilizing 
methods and acceptance criteria consistent with that applicable to Jther safety-related systems in the plant. Presently, those items identified by the licensee as not being fully seismically qualified are evaluated below.

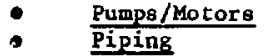

- Valves/Actuators
- $\frac{\text { Power Supplies }}{\text { Water Source(s) }}$
$\frac{\text { Initiation/Gontrol Sygtems }}{\text { Structures }}$
None

The underground portions of the pump minimum flow recirculation lines downstream of the minimun flow orifices are not seismic Category I. However, the licensee stated in their reoponees that the AFW syatem was deaigned to accomplish it required function with failure of these minimum flor recirculation line 8. Therefore we judge that the $A F W$ aystem piping posaesses an overall reismic capability that will withstand a SSE. None None None None None

Based on our evaluation described above, those areas of the AFW syotem judged not to possess a SSE seismic capability are idencified below.

$\begin{array}{ll}\text { - Purps/Motors } & \text { None } \\ \text { - } & \text { Niping } \\ \text { - Valves/Actuators } & \text { None } \\ \text { - } & \text { Nower Supplies } \\ \text { - Water Source(s) } & \text { None } \\ \text { Initiation/Control Systems } & \text { None } \\ \text { Structures } & \text { None }\end{array}$

In sumary, our evaluation indicates that the licensee's AFW system possesses an overall seismic capabilicy that can withstand a SSE.

Because the primary water source and supply path is seismically qualified, switchover to a secondary water source is not involved. In addition, information regarding the seismic capability of any alternate decay heat removal system is not required because the AFW systam is fully seismically qualified.

Regarding the AFW systen boundary, the licensee's responses stated that it fully conforins to the requirements specified in the ceneric Letter.

The licensee also stated that the AFW system was included within the scope of the beismic related NRC Bulletins 79-02, 79-04, 79-07, 79-14, 80-11 and IE Information Notice 80-21.

\subsection{WALKDOWN OF NONSEISHIGALLY-QUALIFIED PORTION OF THE AFW SYSTEM}

A walkdown is not required because we found that no lack of seiamic qualification of the AFw system was indiceted. 
The licensee's responses provided, via references to the applicable sections of the FSAR, a description of the methodologies and acceptance criteria that were used in the deaign of the seismic Category I componenta of the AFW ayetem.

\section{CONCLUSIONS}

The licensee's responses provided all the information that was explicitly requested by GL 81-14. Based on this information, we conclude that the AFW system at Joseph M. Farley Nuclear Plant Usitg 1 and 2 will be able to provide the safety-related function following a SSE to assure safe shutdown of the plant. Therefore, we recommend that no further action be initiated regarding the need of modification/upgrading of the AFW systems of these plants under NRC Multiplant Action C-14.

\section{REFERENCES}

1. D. G. Eisenhrt, "Yfultiplant Action Plan C-14; Seismic Qualification of Auxiliary Feedwater System," U. S. Nuclear Regulatory Combission, memorandum to H. R. Denton (February 20, 1981).

2. U. S. Nuclear Regulatory Comission, Generic Letter to all operating pressurized water reactor licensees, "Seismic Cualification of Auxiliary Feedwater System," (February 10, 1981).

3. F. L. Claytca, Jr., Alabama Power Company, letter to S. A. Varga of U. S. Nuclear Regulatory Comnission, "Seismic Qualification of Auxiliary Feedwater System, Joseph M. Farley Nuclear Plant, Units 1 and 2" (October 9, 1981).

4. S. A. Varga, U. S. Nuclear Regulatory Comission, letter to F. L. clayton, Jr., Alabama Power Company, "Request for Additional Information on Seismic qualification of the Auxiliary Feedwater System, Joseph M. Farley Nuclear Plant, Units 1 and 2" (April 2, 1982).

5. F. L. Clayton, Jr., Alabama Power Company, letter to S. A. Varga of U. S. Nuclear Regulatory Commission, "Seismic Qualification of Auxiliary Feedwater System, Joseph M. Farley Nuclear Plant, Units 1 and 2 " (July 16,1982 ). 


\title{
SEISMIC QUALIFICATION OF AUXILIARY FEEDWATER SYSTEM TECHNICAL, EVALUATION REPORT
}

\author{
FORT CALHOUN STATION: UNIT 1
}

\section{INTRODUCTION}

Since the accident at Three Mile Island thuclear Station, considerable attention has been focused on the capability of nuclear power plants to reliably remove decay heat. The subject of this evaluation is the NRC Multiplant Action Plan C-14, "Seismic Qualification of AFW Systems."I

To implement the first phase of $\mathrm{C}-14$, the NRC issued Generic Letter $81-14$ to all operating PWR licensees, "Seismic Qualification of AFW Systems" dated February 10, 1981.2 This letter requested that each licensee (1) conduct a walkdown of nonseismically-qualified portions of the AFW system and identify deficiencies amenab,le to simple actions to improve seismic resistance and (2) provide design information regarding their specific AFW system seismic capabilities to facilitate NRC backfit decisions.

The licensee of Fort Calhoun Station, Unit 1, responded with a letter dated July 14, 1981, 3 and provided supplemental responses in letters dated September 14,1981 and January $8,1982.4,5$

This report is a technical evaluation based on the information from the licensee's responses to GL 81-14, including recomendations for additional analysis and/or upgrading modification of this plant's AFW system.

\section{EVALUATION}

Information provided in the licensee's responses include:

- Specification of the overall seismic capability of the AFW system.

- Identification of currently nonseismically-qualified components of the AFW system.

- Description of the AFW aystem boundary.

- Status of compliance with seismic related NRC Bulletins and Information Notices.

- Results of walkdown of the AFW system.

- Additionally, information on overall upgrade of the AFW system.

We have reviewed the licensee's responses, and a point-by-point evaluation of the licensee's responses against the Generic Letter's requirements as shown below.

\subsection{SEISMIC CAPABILITY OF THE AFW SYSTEM}

Except for those items identified in the following, the AFW system has been designed, constructed, and maintained to withstand a SSE utilising methode and acceptance criteria consistent with that applicable to other 
a afety-related systems in the plant. Presently, those itemo identified by the licensee as not being fully seimically qualified are evaluated below.

- Pumps/kotors

- Velves/Actuators

- Power Supplies

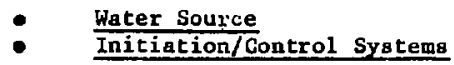

None

(a) The rigidity of the $\mathrm{mmal1}$ bore piping (cold system) was found to be inadequate due to improper aupport opacing, and pipe restraints were to be added. (b) The rigidity of the amall bore piping (hot aystem) appeared to be inadequate although the high temperature $\left(350^{\circ} \mathrm{F}\right)$ of this piping makes it critical to consider potential negative impacts of additional restraints on thermal displacements and loads. The licensee pezformed a detailed pipe atress analysis to determine detrimental impact of additional pipe restraints. The corrective actions for both items (a) and (b) were scheduled for completion by the end of 1981. With the incorporation of these corrective actions we conclude that the AFW system piping would have a SSE level of seismic capability. The operator supports for the valve operators on amall bore piping were found to be unstable. The licensee stated that modification work involved replacing the existing support rods with a more stable support by the end of 1981. With the incorporation of this modification we conclude that the valves/actuator would have a SSE level of seismic capability.

The electrical supply conduit to the AFW pump FW-6 motor had inadequate restraint. An additional support was to be added by the end of 1981 to increase the conduit resistance to seismic movements. With the incorporation of this modification we conclude that the power supplies would have a SSE level of aeiomic capability. None

The instrument air system is not seismically qualified. However, the licensee stated that it is adequately restrained seismically and its failure would not preclude the AFW 
systida operation. We believe thit the instrument air syatem is nonessential to the safety function of the AFW syatem and, hence, the initiation/control ystems posees a SSE level of seimic capability. - Structures None

Based on our evaluation described above, those areas of the AFW system judged not to possess a SSE seismic capability are identified below.

$\begin{array}{ll}\text { - Pumps/Motors } & \text { None } \\ \text { - Piping } & \text { None } \\ \text { - Valves/Actuators } & \text { None } \\ \text { - Poner Supplies } & \text { None } \\ \text { - Water Source } & \text { None } \\ \text { Initiation/Control Systems } & \text { None }\end{array}$

In summary, our evaluation indicated that the AFW system at Fort Calhoun Station Unit 1 , with the incorporation of the modifications to the four deficient items identified previously, would have possessed a SSE level of seismic capability.

Because the primary water supply is seismically qualified, switchover to a secondary water suppiy is not involved.

Information regarding the seismic capability of any alternate decay heat removal system is not required because the AFW oystem would have a SSE level of seismic capability with the incorporation of the modifications to the seismically deficient areas.

Regarding the AFW system boundary, the licensee's responses indicated that it fully conformo to the requirements specified in Generic Letter 81-14.

The licensee stated that the AFW system was included within the scope of seismic related NRC Bulletins 79-02, 79-04,79-07,79-14, 80-11 and IE Information Notice 80-21.

\subsection{WALKDOWN OF NONSEISMIGALLY-QUALIFIED PORTION OF THE AFW SYSTEM}

The licensee conducted a walkdown of the AFW system. The walkdown resulted in the identification of the four seismically deficient items along with the corrective actions as previously described in Section (1). The corrective actions were scheduled for completion by the end of 1981 .

\subsection{ADDIT TONAL INFORMATION}

The licensee's responses stated that an overall upgrade of the AFW system was being implemented as required by NUREG-0737, which is related to, but not a direct result of, the Generic Letter $81-14$. 


\section{CONCLUSTONS}

The information contained in the licensee's reaponses to the Generic Letter 81-14 is complete. The licensee stated that the AFW system boundary fully conforms to the definitions of the Generic Letter 81-14.

Based on the submitted information, we conclude that, with the incorporation of the modifications to the oeismic deficiencies previously identified, the AFW aystem at Port Calhoun Station Unit 1 would have been fully seismically qualified and capable of providing the safecy related function following a SSE. Therefore, we recommend that no further action be initiated regarding upgrading of the $\mathrm{AFW}$ system of this plant under NRC kultiplant Action Plan C-14.

\section{REFERENCES}

1. D. G. Eizenhut, "Multiplant Action Plan C-14; Seismic Qualification of Auxiliary Feedwater System," U. S. Nuclear Regulatory Commission, memorandu: to H. R. Denton (February 20, 1981).

2. U. S. Nuclear Regulatory Commission, Generic Letter to all operating presaurized water reactor ícensees, "Seismic qualification of Auxiliary Feedwater System," (February 10, 1981).

3. W. C. Jones, Omaha Public Power District, letter to D. G. Eisenhut of

U. S. Nuclear Regulatory Commission (July 14, 1981).

4. W. C. Jones, Omaha Public Power Distribt, letter to R. A. Clark of U. S. Nuclear Regulatory Comission (September 14, 1981).

5. W. C. Jones, Cmaha Public Power District, letter to R. A. Clark of U. S. Nuclear Regulatory Commission (January 8, 1992). 


\title{
SEISMIC QUALIFICATION OF AUXILIARX FEEDWATER SYSTEM TECHNICAL EVALUATION REPORT
}

\author{
INDLAN POINT: UNIT 2
}

\section{INTRODUCTION}

Since the accident at Three Mile Island Huclear Station, considerable attention has been focused on the capability of nuclear porer planta to reliably remove decay heat. The subject of this evaluation is the NRG Multiplant Action Plan C-14, "Seismic qualification of AFW Systems."I

To implement the first phase of C-14, the NRC issued Generic Letter 81-14 to all operating PWR licensees, "Seismic Qualification of AFW Syatems" dated February 10, 1981.2 This letter requested that each licensee (1) conduct a walkdown of nonseismically-qualified portions of the AFW oystem and identify deficiencies amenable to simple actions to improve seiamic resistance and (2) provide design information regarding their specific AFW system seismic capabilities to facilitate NRC backfit decisions.

The licensee of Indian Point, Unit 2, responded with a letter dated August $7,1981.3$ The licensee's response was found not to be complete and a Request for Additional Information (RAI) was issued by the NRC, dated April 6 , 1982.4 The licensee provided a supplemental response in a letter dated May $10,1982.5$

This report is a technical evaluation based on the information from the licensee's responses to GL 81-14, including recomendations for additional analysis and/or upgrading modification of this plant'B AFW system.

\section{EVALUATION}

Information provided in the licensee's responses include:

- Specification of the overall seismic capability of the AFW system.

- Identification of AFW syatem componenta that are currently nonseismically qualified by SSE.

Discussion of levels of geismic capability of

nonseismically-qualified AFW system components.

Description of the AFW aystem boundary.

- Status of compliance with seismic related NRC Bulletins and Information Notices.

- Results of walkdown of portions of the AFW aystem.

- Additionally, description of methodologies and acreptance criteria for seismically-qualified portions of the AWW system.

- Additionelly, oummary of recent improvements to the AFW system.
- Additionally, reoults of previous walkdown of the AFW aystem performed both by 1 icensee and resident NRC inspector. 
We have reviewed the licensee' responses, and a point-by-point evaluation of the licensee's reopones against the Generic Letter's requirements as hown below.

\subsection{SEISMIC CAPABILITY OF THE AFW SYSTEM}

Bxcept for those items identified in the following, the AFW system has been designed, constructed, and maintained to withatand a SSE utilizing method. and acceptance criteria consistent with that applicable to other safety-related systems in the plant. Presently, those items identified by the licensee as not being fully seiamically qualified are evaluated below.

- Pumpe/Motors
-

None

None

Licensee has stated that seismic requirements for the AFW oystem were not specifically prescribed in the purchese specifications. However, a licensee ' 8 consultant has determined on a generic basis that seismic capacitieg for the motor and airoperated gate and globe valves range from 0.84 to $23 \mathrm{~g}$ in acceleration with a median value of $7.3 \mathrm{~g}$. Regarding Indian Point unit 2 AFW system valves, the 1 icensee's consultant has determined the median ground acceleration capacity of the water regulator valves and ateam inlet valve to be about $5 \mathrm{~g}$. Assuming a log-normal distribution for both the generic and Indian Point Unit 2 data, we have determined that the lower bound ground acceleration capacity of the water regulator valves and ateam inlet valve is about $0.58 \mathrm{~g}$, which is much greater than the $0.15 \mathrm{~g}$ design ground acceleration for the plant. In light of the large seismic capacities eatablished by the licensee' $a$ consultant and the wide acope of his review, the licensee atated that other air-operated valves in the AWW aystem ahould also have sufficient seismic resistance to withatand a SSE. The licensee also atated that the pneunatic operators on the water regulator valves and steam inlet valve to the turbine are supplied by instrument air system whose compressors are powered from Class 1E sources. If for some reasons the air oupply is loat, valve 
- $\quad \underline{\text { Power Supplies }}$

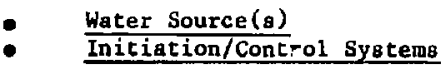

operability is assured by an

automatic high pressure nitrogen bottle aystem. The valves also conservatively fail open on $108 \mathrm{~s}$ of power or air supply. In addition, the water regulator valves and oteam inlet valve may be opened manually in the extremely unlikely event that the fail-safe designed pneumatic operators do not open the valves. Based on the above information provided by the licensee, we judge that the valves possess a seismic capability that will survive a SSE.

The underground power feederg for both motor driven pumps from the $480 \mathrm{~V}$ buses. The licensee indicated, however, these underground conduits are encaged in concrete and have about $1.5 \mathrm{ft}$ of ground cover, and therefore possess substantial amounts of inherent seismic resistance. In addition, there is an alternate power source for one of the motor driven pumps to assure water delivery to the secondary oide of the steam generator if for some reasons the $480 \mathrm{~V}$ bus supplies become unavailable. We thus judge that the underground power feeder possess a SSE seisnic capability. None

Instrumentation and control cables are routed in cable trays that are esseatially unistrut supported and run to the control building through rigid seismic Category 1 structures where no amplification of the $0.15 \mathrm{~g}$ SSE ground acceleration would be expected. Dynamic testing of tray systems similar to those installed at this plant, according to licensee's responses, has indicated that such tray systems have inherent seismic resistant capability in excess of $1 \mathrm{~g}$ of zero period acceleration. We therefore judge that the cable tray systems carrying the instrumentation and control cables possess an inherent seimic capability that will survive a SSE. sone

\section{- Structures}

Based on our evaluation described above, those areas of the AFH system judged not to posaens a SSE seismic capability are identified below. 


$\begin{array}{ll}\text { - Pump/Hotors } & \text { None } \\ \text { - Niping } & \begin{array}{l}\text { None } \\ \text { None }\end{array} \\ \text { - Valves/Actuators } & \text { None } \\ \text { - Power Supplies } & \text { None } \\ \text { - Initer Source(s) } & \text { None } \\ \text { Structures } & \text { None }\end{array}$

Based on the above evaluation, we conclude that the AFW system possesses a SSE level of seiamic capability although portions of the valves, power supplies, and initiation/control aystem are nonseismically qualified.

Because the primary water source and supply path is seismically qualified, a switchover to a secondary water source is not involved. Additionally, information regarding the seismic capability of any alternate decay heat removal system is not required because the AFW system possesses a SSE level of seismic capability.

Regarding the AFW system boundary, the second valve normally closed or capable of automatic closure does not always exist between the AFW system and the nonseismic Category I branch piping. The three specific locations are: (a) the AFW lines to each steam generator join the main feedwater lines downstream of a gate valve and check valve in series on the main feedwater lines (gate valves BFD-7, BFD-7-1, BFD-7-2, BFD-7-3, and check valves BFD-6, BFD-6-1, BFD-6-2, BFD-6-3). These valves provide the boundary betwren the seismic and nonseismic Category I portions of the main feedwater line. The valves are always open. However, should the check valves fail to close completely, sufficient time is available to manually close the gate valves since the AFW system io not required until at last 30 minutes following a reactor trip to prevent the steam generatora from boiling dry. (b) Airoperated butterfly valve LCV -1158 isolates the suction line to the AFW pumps from the nonessential make-up line to the condensor hotwell. The licensee stated that this valve should be capable of operation under SSE loadings. The licensee also stated that the valve is in a vertical line seismically supported to an elevation about 25 feet above the punp inlet and hence failure of the nonseimic Category portion of the line should not adversely affect the water aupply to the pumps. (c) Check valve CD-109 provides the boundary between beismic and nonseismic Category I portions of the make-up water line to the condensate storage tank. The recirculation lines for the auxiliary feeduater pumps feed into the seismic Category I portion of this line. ... recirculation line for the turbine-driven pump is provided with a normally open globe valve; however, the liceneee atated that aufficient time is available to manualiy close this valve if for some reasons the check valve faila to close complecely. Based on the above information, we conclude that the AFW aystem boundary does not fully conform to the definition specified in GL 81-14; however, such deviation would not adversely affect the AFW system in performing the required safety function.

The licensee stated that the AFW system was included within the scope of seismic related Bulletins 79-02,79-04,79-07,79-14, 80-11, and IE Information Notice 80-21. 


\subsection{WALKDOWN OF NONSEISMICALLY-QUALIFIED PORTION OF THE AFW SYSTEM}

A walktown of the nonseismically-qualified portione of the AFW system is required. The licensee stated that recent walkdowns of the AFW syatem were performed to verify the system supports to be in good condition. They did not indicate that the walkdowns specifically covered all noneeismically-qualified portions of the AFW system. However, we conclude that such walkdowns are sufficient because, as diøcussed later in 2.3 Additional Information, previous walkdowns of the AWW system by the licensee and resident NRC inspector appeared to have included the nonseismically-qualified areas of the oystem. The walkdown performed by the resident NRC inspector did not identify unacceptable conditions of the AFW nystem.

\subsection{ADLITIONAL INFOKMATION}

The 1 icensee provided information on the methodologies and acceptance criteria for the seismic design of the seismic category I portions of the AFW system.

The licensee stated that recent improvements to the AFW system have been made in response to NRC requirements identified during the course of the NRC Bulletins and Orders Task Force review following the accident at Three Mile Island, Unit 2, and set forth in the NRC letter of November 7, 1979 to the licensee. These changes, and other design details of the AFW system, are described in licensee' 8 letters to the NRC on December 14, 1979; December 19, 1979; April 14, 1980; July 30, 1980; August 11, 1980; and November 26, 1980.

The licensee also stated that other recent walkdowns were performed. In response to IE Bulletin 79-02, a field inspection and a testing program were performed to verify proper instailation of pipe support plates and expansion anchor bolts, as described in licensee's July 6, 1979 and September 17, 1979 letters to Mr. Grier of Region I office of Inspection and Enforcement of NRC. In response to IE Bulletin 79-14, walkdowns were performed for seismic Category I lines $2.5 \mathrm{in}$. and greater to the extent practicable and qualified personnel has verified the existence, location, and integrity of identified supports as well as the overall piping geometry as described in licensee's August 1, 1979, and September 28, 1979 letters to Mr. Grier. In addition, as reported in Inspection Report No. 50-247/80-15, the resident NRC inspector conducted a walkdown of all accessible portions of the AFW system. The inspector concluded that the 8 ystem was lined up in accordance with licensee's check off 1 ist (DWG. 9321-F-2019, Rev. 25); all hangers and supports appeared to be acceptable; electrical equipment was found to be clear of loose material jumpers, and debris; remote position indication on breakers and valven matched the actual position of the breakers and valves; metering associated with the system was calibrated within the proper calibration dates; and no unacceptable conditions were identified.

\section{CONCLUSIONS}

The information contained in licensee'a repponses to ceneric letter 81-14 is complete. Baged on the submitted information, we conclude that the AFw aystem at Indian Point Unit 2, although not entirely eismically qualified, 
has ressonable assurance to provide the safety-related function following the occurrence if a SSE for aafe shutdown of the plant. Therefore, we recompend no furcher action be initiated regarding reanalyai and/or upgrading

modifications of the AFW system of this plant under NRC Yultiplant Action $c-14$.

\section{REFERENCES}

1. D. G. Eisenhut, "Multiplant Action Plan C-14; Seismic Qualification of Auxiliary Feedwater Syatem," U. S. Nuclear Regulatory Commission, memorandum to H. R. Denton (February 20, 1981 ).

2. U. S. Whclear Regulatory Conmission, Generic ietter to all operating pressurized water reactor licensees, "Seismic Qualification of Auxiliary Feedwater System," (February 10, 1981).

3. J. D O'Toole, Consolidated Edison Company, letter to D. G. Eisenhut of U. S. Nuclear Regulatory Commission (August 7, 1981).

4. S. A. Varga, U. S. Nuclear Regulatory Commission, letter to J. D. o'Toole, Consolidated Edison Company, "Request for Additional Information on Seismic Qualification of the Auxiliary Feedwater System, Indian Point, Unit 2" (January 7, 1982).

5. J. D. O'Tocle, Consolidated Edison Company, letter to S. A. Varga, U. S. Nuclear Regulatory Commission (Kay 10, 1982). 
SEISMIC QUALIFICATION OF IUXILIARY FEEDWATER SYSTEM

TECHNICAL EVALUATION REPORT

INDLAN POINT: UNIT 3

\section{INTRODUCTION}

Since the accident at Three Mile Island Nuclear Station, considerable attention has been focused on the capability of nuclear power plants to reliably remove decay heat. The subject of this evaluation is the NRC Multiplant Action Plan C-14, "Seismic qualification of AFW Systems."I

To implement the first phase of $c-14$, the NRC issued Generic Letter 81-14 to all operating PWR licensees, "Seismic Qualification of AFW Systems" dated February $10,1981.2$ This letter requested that each licensee (1) conduct * walkdown of nonseismically-qualified portions of the AFW system and identify deficiencies amenable to simple actions to improve seismic resistance and (2) provide design information regarding their apecific AFW aystem seismic capabilities to facilitate NRC backfit decisions.

The licensee of Indian Point, Unit 3, responded with a letter dated August 28, 1981. 3 The licensee's response was found not to be complete and a kequest for Additional Information (RAI) was issued by the NRC, dated April 9, 1982.4 The licensee provided a supplemental response in a letter dated September 2, 1982.5

This report is a technical evaluation based on the information from the 1 icensee' $g$ responses to GL $81-14$, including recommendations for additional analysie and/or upgrading modification of this plant's AFW system.

\section{EVALUATION}

Information provided in the licensee's responses include:

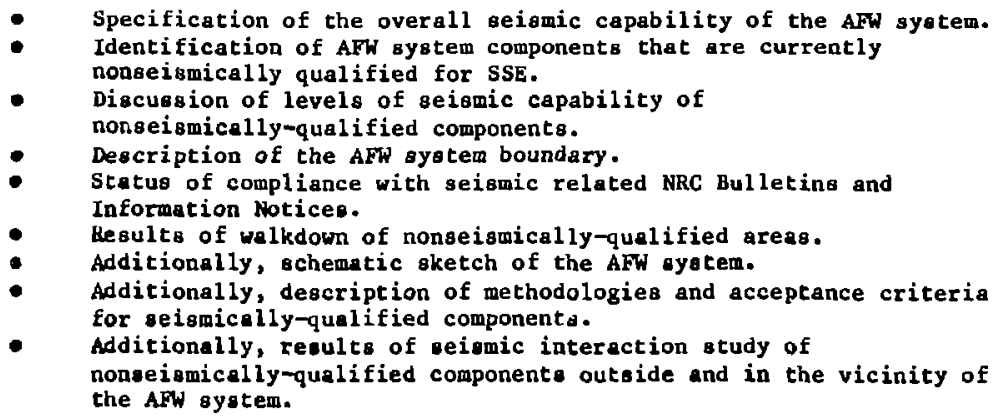


We have reviewed the 1 icensee's responses, and a point-by-point evaluation of the licensee's responses against the Generic Letter's requirements as shown below.

\subsection{SEISHIC CAPABILITY OF THE AFW SYSTEM}

Except for those items identified in the following, the AFW system has been designed, constructed, and maintained to withatand a SSE utilizing methods and acceptance criteria consistent with that applicable to other safety-related systems in the plant. Presently, those items identified by the licensee as not being fully seismically qualified are evaluated below.

\section{- Pumps/Motors}

- Valves/actuators

\section{None}

The portion of the 12 in. piping connecting the hotwell to the AFW suction line (No. CT-1070) that is between values (LCV-1158 and LCV-1128) is seirmic Class III. The licensee stated that it is not necessary to rely upon the operability of this pipe during a SSE in order to provide adequaise flow from the condensate storage tank to the auxiliary feedwater pumpa. They stated that, prior to the condensate storage tank level decreasing to its technical apecification low limit, aut omatic closure of the seismical1y-qualified valve (LCV-1158) and actuation of low level alarm in the control room will occur and the available water is sufficient to remove heat generated by the reactor for 24 hours at hot shutdown conditions. However, we believe that, if this aection of piping should fail during a seirmic event and the single failure is assumed to be the isolation valve (LCr-1158), a path is created that would jeopardize the capability of the condensate atorage tank to provide adequate water to the AFW system. Since the licensee has not indicated plans to upgrade this pipe, we judge that the present level of seismic capability of AFW system piping is less than OBE. Valve (LCV-1128) is seismic Class III. The 1 icensee has stated that they are not planning any action on upgrading this value due to tha diecussion made above in the piping evaluacion section. However, we believe that the valve $4 \mathrm{CV}-1128$ is the second valve required on the AFW oystem 
Power 3upplies

Water Source(s)

Initiation/Control Systems boundary and therefore we judge that the present level of seismic capability of the valves io less than OBE.

The licensee has stated that the seismic qualification data is not available for two notor control. centers (Nos. 34 and 39), two $480 \mathrm{~V}$ switchgear units (NOB. 31 and 32 ), and three 125 VDC power panels (Nos. 31, 32 , and 33). Investigations are currently underway with the vendors and they are scheduled to be completed prior to start-up from the cycle $4 / 5$ refueling outage which would occur in the summer of 1984. However, the licensee did not indicate that identified deficiencies would actually be coirected. We judge that the power supplies currently possess a level of seismic capability less than the OBE. None

(a) The licensee has stated that the seismic qualification data is not available for the speed control system for the turbine AFW pump, the ITT Barton flow control switches (FC-1135S and 1136S), and static "O" ring. The licensee indicated that these deficiencies would be investigatei with the vendor, but did not indicate that corrective actions will be taken. (b) Field routed instrument air piping in the AFW pump room is currently supported by rod haugers or frictional clamps which appear to lack sufficient seismic resistance. The licensee plans to provide additional restraints and/or modify the existing ones. (c) Instrumentation and control rack No. 28 is free standing without any bolts. Moreover, the grout is not provided and the bottom of the rack is rusted. Corrective actions are planned. (d) Nitrogen bottles are free standing and tied only with chains and ropes. Additional restraints have been planned. (e) AFW pumps local control panel appears to lack adequate seismic resistance in the lateral direction. The licensee plans to check with the vendor for additional lateral oupport or X-bracing; however, corrective actions are not committed to. 
Actions for 911 items degcribed above are plained for completion before 6 tartup from the cycle $4 / 5$ refueling outage which would occur in the summer of 1984. Because no commitmenta for upgrade/modification have been identified for items (a) and (e), we conclude that the geismic capability of the initiation/control systems is less than OBE. The turbine building is seismic class III, and it supports and/or houses the 12 in. pipe (CT-1070), valve LCV-1128, and possibly some other essential AFW system components. The licensee has no plans to upgrade/modify this building. We therefore conclude that the present level of seismic capability of the structures is less than $\mathrm{OBE}$.

Based on our evaluation described above, those areas of the AFH system judged not to possess a SSE seismic capability are identified below.

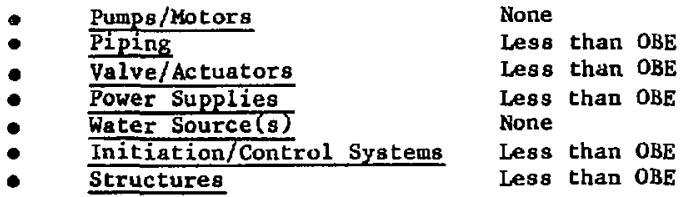

In summary, our evaluation indicates that the licensee's AFW system does not possess an overall seismic capability that can withstand a SSE.

The primary water source is the condensate storage tank which is seismically qualified. A secondary water source is provided from the honqualified city water system. However, since the primary water source and supply path is seismically qualified, switchover to a secondary water source is not involved.

Seismic qualification information for any alternate decay heat removal system was requested by the Generic Letter 81-14 if substantial lack of seismic qualification of the AFW system is indicated. We did not find that the licensee's AFW system has a SSE capability, and the licensee's responses did not provide information on any alternate decay heat removal system.

Regarding the AFW system boundary, the licensee stated that it fully sonforms to the definitions of GL 81-14. However, the branch line (CT-1070) is a part of AFW system and has a nonqualified second isolation valve (LCV-1128) which the licensee has no plans for upgrading. We therefore believe that the AFW aystem boundary does not fully conform to the definition of GL $81-14$. 
The licensee stated that the AFW system was included within the scope of the seismic related NRC Bulletin 79-02, 79-04, 79-07, 79-14, and 80-11. Regarding the IE Information Notice 80-21, nine representative items have been evaluated and the results are generally applicable to the AFW system.

\subsection{WALKDOWN OF WONSEISMICALLY-QUALIFIED PORTION OF THE AFW SYSTEM}

The licensee stated that a waskuwn of the AFW system was jointly performed by the licensee and their consultant, Ebasco Services, and it was limited to the AFW pump building where the major portion of the AFW system is located. Also components of the support system were followed outside the building to maximum possible and practical extent. Walkdown of the Class III pipe (CT-1070) indicated that it has inadequate supports. It has been proposed by the licensee's consultant to provide three orthogonal restraints to the portion of this pipe in the pump building, and the licensee has decided not to perform any action on this item as was previously discussed under the piping evaluation. Walkdown on the initiation/control syatems has identified several deficiencies along with corrective actions as previously discussed under the initiation/control systems evaluation. In conclusion, we believe that the walkdown is not complete because it did not cover the nonseismically-qualified turbine building and the valve (LCV-1128).

\subsection{ADDI TIONAL INFORMATION}

The licensee provided a schematic sketch of the AFw systew including the water sources, heat sink, suction and discharge piping, major mechanical equipment, and structures supporting and housing the AFW system items.

Additionally, licensee's responses pruvided a description of the methodologies, loading combinations and acceptance criteria that were used in the design of the seiamically-qualified portions of the AFW system by referring to the appropriate sections of the FSAR.

Additionally, the licensee provided the results of a seismic interaction study of the components outside and in the vicinity of the AFW system, to assess their effect on the AFW aystem. The components in the following list are sonsidered by the licensee to be the major contributors to unacceptable interaction affecting $A F W$ system functionalicy: (a) Crane/monorail structure lorated directly above the two motor driven and the turbine driven AFW pumps. (b) 4-in. nonseismic floor drain pipe directly above the electrical cable trays containing esgential safety related equipment. (c) Space heaters and electrical lighting fixtures located directly above essential safety related equipment and structures. (d) Nonseismic electrical cable trays and conduit routed directly above essential safety related equipment and structures. e) Large nonseismic instrument racks located within close proximity to essential safety related equipment and structures. (f) Large roll-up door located in the shieldwall whose stcuctural failure could affect the flow control stations of the turbine driven AFW pumps. The licensee did not indicate any plans to investigate or correct the above mentioned deficienciea. 


\section{CONCLUSIONS}

The information contained in licensee's responses to the Generic Letter 81-14 is complete. The licensee identified the nonseiswically-qualified portions of the AF system and conducted a partial walkdown of these items. Inveatigations of the power supplies and initiation/control aystems were acheduled by the licensee to be completed before the cycle $4 / 5$ refueling outage in the summer of 1984. No plans were given, however, for any possible actions resulting from such investigations. Also, we conclude that the AFw system boundary does not fully conform to the boundary definitions apecified in the Generic Letter $81-14$.

Based on the submitted information, we conclude that presently the AFW system at the Indian Point, Unit 3 Nuclear Plant cannot withstand a SSE. Therefore, we recommend that the NRC consider requiring the licensee: (a) to complete the walkdown of the nonseismically-qualified components of the AFW system with in a reasonable time, and (b) to upgrade/modify the nonseismically-qualified portions of the AFW system under NRC Multiplant Action Plan C-14.

\section{REFERENCES}

1. D. G. Eisenhut, "Multiplant Action Plan C-14; Seismic Qualification of Auxiliary Feedwater System," U. S. Nuclear Regulatory Commission, memorandum to H. R. Denton (February 20, 1931).

2. U. S. Nuclear Regulatory Commission, Generic Letter to all operating pressurized water reactor licensees, "Seismic Qualificstion of Auxiliary Feedwater System," (February 10, 1981).

3. J. P. Bayne, Power Authority of the State of New York, letter to D. G. Eisenhut of U. S. Nuclear Regulatory Commission (August 28, 1981 ).

4. U. S. Nuclear Regulatory Commission, letter to Power Authority of the State of New York, "Request for Additional Information on Seisuic Qualification of the Auxiliary Feedwater System, Indian Point, Unit $y$ Nuclear Power Plant" (April 9, 1982).

5. J. P. Bayne, Power Authority of the State of New York, letter to S. A. Varga of U. S. Nuclear Regulatory Commission (September 2, 1982). 


\section{SEISMIC QUALIFICATION OF AUXILIARY FEEDWATER SYSTEM TECHNICAL EVALUATION REFORT}

KEWAUNEE NUGLEAR PLANT

\section{INTRODUCTION}

Since the accident at Three Mile Island Nuclear Station, considerable attention has been focused on the caprbility of nuclear power plants to reliably remove decay heat. The subjuct of this evaluation is the NRC Multiplant Action Plan C-14, "Seismic Qualification of AFW Systems."I

To implement the first phase of C-14, the NHC issued Generic Letter 81-14 to all operating PWR licensees, "Seismic Qualification of AFW Systems" dated February 10, 1981.2 This letter requested that each licensee (1) conduct a walkdown of nonseismically-qualified portions of the AFW system and identify deficiencies amenable to simple actions to improve seismic resistance and (2) provide design information regarding their specific AFW system seismic capabilities to facilitate NRC backfit decisions.

The licensee of Kewaunee Nuclear Plant responded with a letter dated August $28,1981.3$ The licensee's response was incomplete and a Request for Additional Information (RAI) was issued by the NRC, dated February 25, 1982.4 The licensee provided a supplemental response in a letter dated April 8, 1982.5

This report is a technical evaluation based on the information from the licensee's responses to GL 81-14, including recommendations for addi. inal analysis and/or upgrading modification of this plant's AFW system.

\section{EVALUATION}

Information provided ir the licensee's responses include:

- Specification of the overall seismic capability of the AFW system.

- Identification of currently nonseismically-qualified components of the AFW system.

- Description of procedure for switchover to a seismically-qualified secondary water source.

- Description of the AFW system boundary.

- Status of compliance with seismic related NRC Bulletins and information Notices.

- Additionally, isometric drawings of the AFW system.

- Additionally, description of methodologies and acceptance criteria for seismically-qualified components.

We have reviewed the licensee's responses, and a point-by-point evaluation of the licensee's responses against the GL 81-14's requirements as shown below. 


\subsection{SEISMIC CAPABILITY OF THE AFW SYSTEM}

Except for those items identified in the following, the AFW system has been designed, constructed, and maintained to withstand a SSE utilizing methods and acceptance criteria consistent with that applicable to other safety-related systems in the plant. Presently, those items identified by the licensee as not being fully seismically qualified are evaluated below.

\section{- Pumps/Motors}

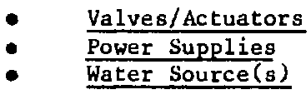

\section{None}

The portion of the recirculatiun line from the discharge of the AFW pumps to the condensate storage tank. This branch line was originally designed to the pipe anchors as a seismic class I line. A subsequent design change relocated the Class I boundary of this line. As a result, additonal piping, i.e., a nonseismical ly-qualified portion of the recirculation line beyond the pipe anchors was included within the relocated $\mathrm{Class} I$ boundary. The licensee stated that they are currently verifying the seismic design and will submit their finding ata future date. Until such information is submitted by the licensee, we cannot determine the seismic capability of the addition: piping in question and and we judge that it probably possesses a seismi. capability that will survive an operating basis earthquake (OBE). None.

None.

The primary water source, the condensate system, is not entirely seismically qualified. Only a portion of the condensate system from the piping anchor (three orthogonal restraints) through to the coupling to the AFW system is fully qualified seismically. The licensee did not describe the original seismic design level for the condensate system. However, they indicated that it does not present any unanalyzed, seismically-induced loads on the Atn systern and that a secondary water source and supply path, the service water system, is available to pro. a backup water supply to the $A F W$ system. The portion of the service water systen, which supplies supplies water to the AFW system, is seismical'y qualified, and a 
procedure (A-FW-05B) includes the remote operation of the service-water supply valves from the control room. - Initiation/Control Systems None None

Based on our evaluation described above, those areas of the AFW system judyed not to possess a SSE seismic capability are identified below.

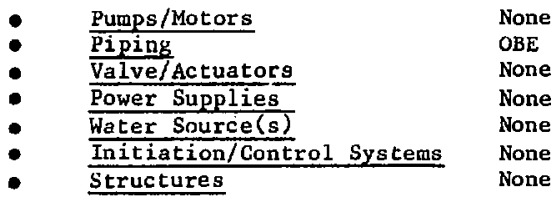

In summary, our evaluation indicates that the AFW system at Kewaunee Nuclear Plant does not presently possess an overall level of seismic capability that can survive a SSE, because a portion of the recirculation line is currently nonseismically qualified.

The primary water source and supply path is not wholly seismically qualified and, therefore, switchover to the seismically-qualified secondary water source and supply path is required. A switchover procedure is available.

Seismic qualification information for any alcernate decay-heat removal system was not provided in the licensee's responses. This information was requested by GL $81-14$, if substantial lack of seismic qualification is indicated for the AFW system. Although we judg that the existing AFW system does not possess a SSE level seismic capability, we conclude that such information for any alternate decay-heat removal system is not required at the present, because the licensee has stated that they are in the process of verifying the seismic design of the additional piping on the recirculation line to the condensate storage tank, and that the conclusion will be submitted at a later date.

Megarding the AFW system boundary, we conclude that it fully conforms to the requirements of GL $81-14$.

The licensee stated that the AFW system was included within the scope of the seismic related NRC Bulletin 79-02, 79-04,79-07, 79-14, and 80-11, and IE Information Notice $80-21$.

\subsection{WALKDOWN OF NONSEISMICALLY-QUALIFIED PORTION OF THE AFW SYSTEM}

A walkdown of the nonseismically-qualified portion of the branch piping is required. The licensee's responses did not indicate that they conducled the wlakdown, although they are presently verifying the seismic design of the nonseismically-qualified portion of the branch piping. We conclude that the information on the required walkdown is not complete.

\subsection{ADDITIONAL INFORMATIUN}

T. 1 icensee provided four isometric drawings of the AFW system that identicy the oeismic Class I piping, water sources, heat sinks, and all major mechanical equipment. 
Additionally, licensee's responses stated that description of the methodologies used in the seismic qualification of ther A.TW syster is provided in the icensee's letter of July $9,1979.6$

\section{CONCLUSI'INS}

The information contained in licensee'/3 responses to the GL 81-14 is not sufficient with regard to seismic qualification of the recirculation line. The licensee did not conduct a walkdown of the non-seismically-qualified portion of the recirculation line. However, they stated that verification of the seismic capability of the recirculation line is underway and the conclusion will be provided at a later date.

Based on the submitted information, we conclude that the AFW system at the Kewaunee Nuclear Plant does not provide a reasonable assurance to perform its required safety function following a SSE, because the nonseismically-qualified portion of the recirculation line is judged to have only a OBE level resistance. Since the licensee is currently verifying the seismic design of the piping in question, we recommend that no action be initiated regarding additonal analyses and/or upgrading modifications of the AFW system of this plant under NKC Multiplant Action $\mathrm{C}-14$, pending the licensee's conclusion from their ongoing verification.

\section{REFERENCES}

1. D. G. Eisenhut, "Multiplant Action Plan C-14; Seismic Qualification of Auxiliary Feedwater System," U. S. Nuclear Regulatory Comission, memorandum to H. K. Dent, (February 20, 1981).

2. U. S. Nuclear Kegulatory Comnission, Generic Letter to all operating pressurized water reactor licensees, "Seismic Qualification of Auxiliary Feedwater System," (February 10, 1981).

3. E. K. Mathews, Wisconsin Public Service Corporation, letter to S. A. Varga of the U. S. Nuclear Regulatory Commission, August 14, 1981.

4. S. A. Varga, U. S. Nuclear Regulatory Comission, letter to E. R. Mathews, Wisconsin Public Service Corporation, "Request for Additional Information on Seismic Qualification of the Auxiliary Feedwater System, Kewaunee Nuclear Plant", February 25, 1982.

5. E. K. Mathews, Wisconsin Public Service Corporation, letter to S. A. Vargn, U. S. Nuclear Regulatory Commission, April 8, 1982.

6. E. R. Mathews, Wisconsin Public Service Corporation, letter to J. G. Keppler, U. S. Nuclear Kegulatory Commission, July 9, 1979. 


\section{SEISMIG QUALIFICATION OF AUXILIARY FEEDWATER SYSTEM TECHNICAL EVALUATION REPORT}

MAINE YANKEE NUCLEAR PLANT

\section{INTKODUCTION}

Since the accident at Three Mile Island Nuclear station, considerable attention has been focused on the capability of nuclear power plants to reliably remove der.dy heat. The subject of this evaluation is the NRC Multiplant Action Plan C-14, "Seismic Qualification of AFW SyBtems."1

To implement the first phase of $\mathrm{C}-14$, the NRC issugd Generic Letter $81-14$ to all operating PWK licensees, "Seismic Qualification of AFW Systems" dated February 10, 1981.2 This letter requested that each licensee (1) conduct a walkdown of nonseismically-qualified portions of the AFW system and identify deficiencies anenable to simple actions to improve seismic resistance and (2) paivide design infortation regarding their specific AFW system seismic capabilities to facilitate NRC backfit decisions.

The licensee of Maine Yankee Nuclear Plant responded with a letter dated August 5, 1981.3 The licensee's responge was incomplete and a Request for Additional Information ( $R A I$ ) was issued by the NRC, dated April 2, 1982.4 The licensee provided a supplemental response in a letter dated May 27 , 1982.5

This report is a technical evaluation based $c n$ the information from the licensee's responses to GL $81-14$, including recommendations for additiona 1 analysis and/or upgrading rodification of this plant's AFW system.

\section{EVALUATION}

Information provided in the licensee's responses include:

- Specification of the overall seismic capability of the AFW system.

- Identification of AFW system components that are currently nonseismically-qualified for SSE.

- Discussion of levels of seismic capability of certain nonseismically-qualified components.

- Liescription of the AFW system boundary.

- Status of compliance with seismic related NKC Bulletins and Information Notices.

- Hesults of walkdown of portions of nonseismically-qualified areas.

- Additionally, verification of the program currently being conducted by licensee to reaffirm or qualify the AFW system piping, and the schedules for modifications, if found necesary, as a result of this program.

We have reviewed the licensee's responses, and a point-by-point evaluation of the licensee's responses against the GL 81-14's requirements as shown below. 


\subsection{SEISMIC CAPABILITY OF THE AFW SYSTEM}

Except for ti ose items identified in the following, the AFw system has been desigued, constructed, and maintained to withstand a SSF, utilizing methods and acceptance criteria consistent with that applicaile to other safecy-related systems in the plant. Presently, those items identified by the licensee as not being fully seiamically qualified are evaluated below.

- $\quad \frac{\text { Pumps/Motors }}{\text { Piping }}$

Valves/Actuators

\section{None}

(a) Licensee stated that a small-bore minimum flow recirculation piping from the discharge of the $A F W$ pumps was not fully qualified for SSE. No discussion was given regarding its seismic capability. (b) Licensee stated that the majority of large-bore suction piping from the demineralized-water storage tank to the AFW pumps was analyzed for some seismic loads. However, the specific level of the seismic loads was not discussed. (c) The initial design and construction of small-bore piping did not consider seismic loads, according to the licensee, and there was no discussion on the seismic capacity of the small-bore piping. From the above information, we judge that the seismic capacity of the piping system is presently less than an $O B E$ level. The licensee stated that they are currently reaffirming all previcus seismic analyses of the piping system. The scope of the program will be increased to include the soismic qualification of the piping supplying each steam generator to the SSE level. if deficiencies are found in the piping system, corrective actions will be implemented and any necessary physical changes to assure the capability of auxillary feedwater delivery to the steam gei-'-ator will be accomplished during the next scheduled refueling outage after August 5, 1981 . Licensee stated that valve actuators were not seismically qualified, but will be either qualified for certain seismic luads or replaced, concurrent with the program for piping seismic qualification. We judge that the actuators presently possess a less than $O B l$ level of seismic capability. 
The seismic capacity of conduit is currently unknown and the licensee wil assess the feasibility of qualifying the conduits as time permits. We, therefore, judge that the conduits presently possess a less

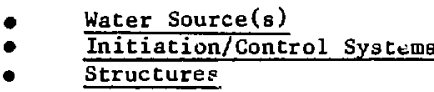
than $O B E$ level of seismic capability. None

None

None

Based on our evaluation described above, those areas of the AFW system judged not to possess a SSE seismic capability are identified below.

- $\frac{\text { Pumps/Motors }}{\text { - }}$
- $\frac{\text { Valving }}{\text { - }}$ - Water Suctuators
$\frac{\text { Initiation/Control Systems }}{\text { Structures }}$

None
None*
None*
Less
None
None
None

summary, our evaluation indicates that licensee's AFW system does not presenty possess an overall seismic capability that can withstand a SSE.

The primary water source is seismically qualified, but the supoply path is not wholly seismically qualified. Therefore, infurmation on switchover to a seismically-qualified secondary water source supply path is required. This information is not available from 1 icensee's responses, and it appears tha' a seismically-qualified secondary water source and supply path does not presently exist. However, a switchover will not be involved when the licensee completes the upggrade/modification of the primary water supply line by the next refueling outage.

Seismic qualification information for any alternate decay-heat removal system was not provided in the licensee's responses. This information was requested by GL $81-14$, if substantial lack of seismic qualification of the AFW system is indicated. We did not find that the licensee's AFW system has a SSE capability. However, we conclude that such iniormation for any alternate decay-heat removal system is not required, because the licensee has stated that they are reanalyzing and/or modifying the $A F W$ system piping and valve actuators, and that they will assess the feasibility of qualifying the conduits as time permits.

Kegarding the AFW system boundary, the licensee indicated that the orjginal seismic design criteria considered the first normally-closed isolation valve as the seismic boundary for branch piping, and the licensee's ongoing seismic qualification program for the AFW aystem piping will verify the seismic integrity of the branch piping beyond the first normally-closed valve to a point of three orthogonal restraints. One exception to this boundary classification is the condensate makeup and spill line connected to the demineralized-water storage tank. Currently, this line is under review for determination of Beismic adequacy end/or modification. Based on the above information, we conclude trat the AFW system boundary line does not fully conform to the definition specified in GL 8l-14. 
The licensee stated that the AFW system was included within the scope of IE bulleting 79-04 and 80-11. The seismically-qualified portions of the AFW system piping were addressed in the licensee's responses to IE Bulletins 79-02, 79-07, and 79-14. The presently nonseismically-qualified portions of the AFW system piping wil be incluced within IE Bulletins 79-02, 79-07, and 79-14 as part of the licensee's ongoing seismic-qualification assessment program. The licensee indicated that initial review of the IE Informaton Notice 80-21 did not result in recomnended actions, and that they will reconsider $80-21$ as time permits, through the seismic-qualification assessment program. Based on the above information, we conclude that the licensee's AFW system will comply with all seismic-related NRC bulletins and Information Notices, when the licensee completes their seismic-qualification assessment program.

\subsection{WALKIYWN OF NONSEISMICALLY-QUALIFIED PORTION OF THE AFW SYSTEM}

A walkdown of the currently nonseismically-qualified portions of the AFW system is required. The licensee indicated that a field of wa?ksown was conducted only for the small-bore branch piping. We conclude hat the information on the required walkdown is not com; ite.

\subsection{ADDIT IONAL INFORMATION}

The licensee indicated that they are currently con'reting the seismic-qualificaton assessment program for the AFW system pipung and valve accuators. The program will be increased to include qualifying the AFW system piping supplying each steam generator to the SSE level. In the conduct of this progran, corrective actions will be implemented, if deficiencies are found and physical changes, if necessary, will be accomplished to assure the capability of feedwater delivery to the steam generator during the next scheduler refueling outage after August 5, 1981 .

\section{CONCLUSIONS}

The information contained in licensee's responses to GL 81-14 was not sufficient for us to evaluate the overall seismic capability for the existing AFW system. Except for the small-bore branch piping, a walkdown for the presently nonseismically-qualified AFW system piping, actuators, and conduits has not been performed. It is also noted that the AFW system boundary does not fully conform to the definition specified in GL B1-14.

Hased on the submitted information, we conclude that the AFW system at the Maine Yankee Nuclear Plant will not be able to perform the safety-relaced function following the occurance of a SSE, because the seismic capabili y of conduit in the power supplies is surrently unknown and the licensee has not identified a specific assessment program for the conduit. The current seismic qualification assessment program, which the licensee stated will be completed by the next refueling outage, will reaffirm and/or upgrade the seismic qualification of the AFW system piping and valve actuators. Since the licensee does not presnetly plan to analyze and/or upgrade the conduit, we recommend that the NKC considers requiring the licensee to provide a reanalysis and/or morification to acquire a SSE capacity for the conduit. 


\section{REFERENCES}

1. D. G. Eisenhut, "Multiplant Action Plan C-14; Seimic qualification of Auxiliary Feedwater Syatem," U. S. Nuclear Regulatory Commission, memorandum to H. R. Denton (February 20, 1981).

2. U. S. Nuclear Regulatory Commiseion, Generic Letter to all operating pressurized water reactor licensees, "Seienic Qualification of Auxiliary Feedwater System," (February 10, 1981).

3. W. P. Johnson, Maine Yankee Atomic Power Company, letter to Office of Nuclear Reactor Regulation of the U. S. Nuclear Regulatory Commission, Augugt 5, 1981 .

4. R. A. Calrk, U. S. Nuclear Regulatory Commission, letter to J. H. Garrity, Maine Yankee Atomic Power Company, "Request for Additional Information on Seimic Qualification of the Auxiliary Feedwater System, D. ine Yankee Nuclear Plant", April 2, 1982.

5. J. H. Garricy, Maine Yankee Atomic Power Company, letter to R. A. Clark, U. S. Nuclear Regulatory Commission, May 27, 1982. 


\section{SEISMIC QUALIFICATION OF AUXILIARY FEEDWATER SYSTEM TECHNICAL EVALUATION REPORT}

McGUIRE NUClEaR STATION, UNITS 1 AND 2

\section{INTRODUCT ION}

Since the accident at Three Mile Island, considerable attention has been focused on the capability of nuclear power planto to reliably remove decay heat. The NRC has recently undertaken Multiplant Action Plan C-14 "Seismic Qualification of AFW Systems," which is the subject of this evaluation.

To implement the first phase of Action Plan C-14, the NRC issued Generic Letter No. 81-14 "Seismic Qualification of AFW Systems,"2 dated February 10, 1981, to all operating PWR 1 icensees. This letter requested each licensee ( 1 ) to conduct a walkdown of nonseismically qualified portions of the AFW system and identify deficiencies amenable to simple actions to improve seismic reaistance, and (2) to provide design information regarding the seismic capability of the AFW system to facilitate NHC backfit decisions.

Since the accident at Three Mile Island, considerable atcention has been focused or the capability of nuclear power plants to reliably remove decay heat. The NRC has recently undertaken Multiplant Action Plan C-14 "Seismic Qualification of AFW Systern", 1 which is the subject of this evaluation.

To implement the first phase of Action Plan C-14, the NRC issued Generic Letter No. 81-14 "Seismic Qualification of AFW Systems,"2 dated February 10, 1981, to all operating PWR licensees. This letter requested each licensee ( 1 ) to conduct a walkdown of nonseismically qualified portions of the AFW system and identify ueficiencies amenable to simple actions to improve seismic resistance, and (2) to provide design information regarding the seismic capability of the AFW system to facilitate NKC backfit decisions.

The licensee of McGuire Nuclear Station, Units 1 and 2 , responded with a letter dated July $15,1981,3$ and there was no supplemental response required in orde: to complete our evaluation.

This report is a technical evaluation based on the information from the licensee's responses to $\mathrm{GL} 84-14$, including recomendations for additional analysis and/or upgrading modification of this plant's AFW system.

\section{EVALUATION}

Information provided in the licensee's response include:

- Specification of the overall seismic capability of the AFW system.

- Identification of currently nonseismically-qualified components of the AFW system.

- Description of procedure for switchover to a seismicaliy qualified water source.

- Description of the AFW system boundary.

- Status of compliance with seismic related NRC Bulletins and Informetion Notices.

- Additionally, Bchemaric sketches of the AFW system.

- Additionally description of methodologies and acceptance criteria for the design of seismically qualified components. 
We have reviewed the lice isee's responses, and a point-by-point evaluation of the licensee's cesponses against the GL $81-14$ 's requirements as shown below.

\subsection{SEISMIC CAPABILITY OF THE AFW SYSTEM}

Except for those items identified in the following, the AFW system has been designed, constructed, and maintained to withstand a SSE utilizing methods and acceptance criteria consistent with that applicable to other safety-related systems in the plant. Presently, those items identified by the licensee as not being fully seismically qualified are evaluated below.

$\begin{array}{ll}\text { - } & \frac{\text { Pumps/Mocors }}{\text { Piping }} \\ - & \frac{\text { Valves/Actuators }}{\text { Power Supplies }} \\ \text { Water Source(s) }\end{array}$

- Initiation/Control Systems

\author{
None \\ None \\ None \\ irone \\ The normal water source, i.e., the \\ condensate storage tank, is not \\ seismically qualified. However, the \\ primary water supply from the Nuclear \\ Service Water (RN) System is \\ seismically qualified. A procedure \\ is available for switching from the \\ normal to the primary water source. \\ Therefore, we conclude that the water \\ sources possess a SSE level of \\ seismic capability. \\ None \\ None
}

Based on our evaluation described above, those areas of the AFw system judged not to possess a SSE seismic capability are identified below.

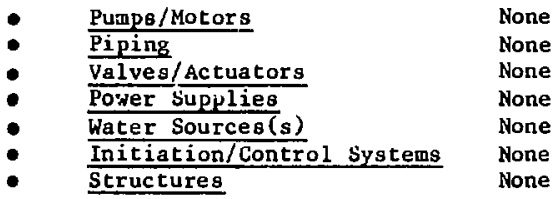

In sumary, our evaluation indicated that the AFW systen at McGuire Nuclear Station, Units 1 and 2, possesses a SSE level of seismic capability.

The normal water supply from the condensate storage tank is not seismically qualified and, therefore, switchover to the seismically qualified primary water supply, the RN System, is required. The switchover procedure consists of automatic alignment of the AFW pumps to the RN System on low-suction pressure, as described in the FSAR, Section 10.4.7.2.2. This procedure his been found acceptable to the NRC in its safety evaluations for the operating licenses for McGuire Nuclear Station, Units 1 and 2.

Information regarding the selomic capability of any alternate decay heat renoval bystem is not required because the AFW system has a SSE level of seismic capability. 
Regarding the AFW system boundary, the licensee's responses indicated that it fully conforms to the reguirements specified in GL 81-14 81-14.

The licensee stated that the AFW gystem was included within the scope of seismic related NRC Bulletins 79-02, 79-04, 79-07, 79-14, 80-11 and IE Information Notice $80-21$.

\subsection{WALKDOWN OF NONSEISMICALLY-QUALIFIED PORTIUN OF THE AFW SYSTEM}

A walkdown is not required because no lack of seismic qualification of the AFW system is indicated.

\subsection{ADDIT IONAL INEORMATION}

The 1icensee provided a schema'ic diagram of the AFW system pump suction and diacharge, and a diagram of the stean generator side feedwater piping. Additionally, licensee's responses provided a description of the methodologies and acceptance criteria for the design of the seismically qualified components, including a reference to the applicable sections of the FSAR.

\section{CONGLUSIONS}

The information contained in licensee's responses to the GL $81-14$ 81-14 is complete. The licensee stated that the AFW system boundary fully conforms to the definitions of the GL $81-14$.

Based on the submitted information, we conclude that the AFW system at McGuire, Nuclear Station, Units 3 and 2 , is fully seismically qualified and is able to provide the safety related function following a SSE. Therefore, we recommend no further action be initiated regarding upgrading of the AFw system of this plant under NRC Multiplant Action Plan C-14.

\section{REFERENCES}

1. D. G. Eisenhut, "Multiplant Action Plan C-14; Jeismic Qualification of Auxiliary Feedwater System," U. S. Muclear Regulatory Commission, memorandum to H. R. Denton (February 20, 1981).

2. U. S. Nuclear Kegulatory Commission, Generic Letter to all operating pressurized water reactor licensees, "Seismic Qualification of Auxiliary Feedwater System," (February 10, 1981).

3. W. O. Parker, Jr., Duke Power Co., letter to H. R. Denton of U. S. Nuclear Regulatory Commission, July 15, 1981. 


\section{SEISMIC QUALIFICATION OF AUXILIARY FEEDWATER SYSTEM TECHNICAL EVALUATION REPORT}

MILLSTONE NUCLEAR POWER STATION, UNIT 2

\section{INTRODUCTION}

Since the accident at Three Mile Jsland, considerable attention has been focused on the capability of nuclear power plants to reliably remove decay heat. The NKC has recently undertaken Multiplant Action Plan C-14 "Seismic Qualification of AFW Systems,"l which is the subject of this evaluation.

To implement the first phase of Action Plan C-14, the NRC issued Generic Letter No. 81-14 "Seismic Qualification of AFW Systems,"2 dated February 10, 1981, to all operating PWR licensees. This letter requested each licensee (1) to conduct a walkdown of nonseismically qualified portions of the AFW system and identify deficiencies amenable to simple actions to improve seismic resistance, and (2) to provide design information regarding the seismic capability of the AFW system to facilitate NRC backfit decisions.

The licensee of Millatone Nuclear Power Station, Unit 2, responded with a letter dated July 24, 1981.3 The licensee's response was found not to be complete and a request for Additional Infurmation (RAI) was issued by the NRC, dated April 15, 1982.4 The licensee provided a supplemental response in a letter dated June $4,1982.5$

This report is a technical evaluation based on the information from the licensee's responses to GL $81-14$, including recommendations for additional analysis and/or upgrading modification of this plant's AFW system.

\section{EVALUATION}

Information provided in the licensee's response include:

- Specification of the overall Beismic capability of the AFW system.

- Description of methodologies and acceptance criteria for seismic design of the AFW system, which is determined to be saismically qualified to the SSE level by the licenaee.

- Description of the AFW system boundary.

- Status of compliance with seismic related NRC Bulleting and Information Notices.

- Additionally, results of walkdown of the AFW system and identification of areas of modification/upgrade that have been completed or are proposed along with a schedule.

We have reviewed the licensee's responses, and a point-by-point evaluation of the licensee's responses against the GL $B L-14^{\prime} s$ requirements as shown below. 


\subsection{SEISMIC CAPABILITY OF THE AFW SYSTEM}

The AFW system has been designed, constructed, and maintained to withstand a SSE utilizing methods and acceptance criteria consiscent with that applicable to other safety-related systems in the plant. All areas of the AFW Bystem, i.e., pumps/motors, piping, valves/actuators, power supplies, water source, instrument/control systems, and structures supporting and housing the AFW system, are seismically qualified to the SSE level.

The licensee provided a description of the methodologies and acceptance criteria used for seismic qualification of the AFW system, and referred to the applicable sections of the FSAR. The description includes seismic analysis methods, seismic input, load combinations, allowable stresses, qualification testing, and engineering evaluations performed.

A switchover procedure to a secondary water source is not involved because the primary water source and supply pach is seismically qualified.

Information regarding the seismic capability of any alternate decay heat removal system is not required because the AFW system is fully suismically qualified.

Regarding the AFW system boundary, te conclude that it fully conforms to that required by GL $81-14$. The licensee stated that the AFW system was included within the scope of the seismic related NRC Bulletins 79-02, 79-04, 79-07, 79-14, 80-11, and IE Information Notice 80-21.

\subsection{WALKDOWN OF NONSEISMICALLY-QUALIFIED PORTION OF THE AFW SYSTEM}

A walkdown is not required because no lack of seismic qualification of the AFW system is indicated.

\subsection{ALDIT IONAL INFORMATION}

The licensee indicated that a walkdown was performed in response to IE Bulletin 79-14. In addition, licensee opted to complete a walkdown of AFW system. This walkdown included mechanical and electrical equiprent, piping, cable trays, and conduit.

In walkdown related to IE Bulletin 79-14, forty-three supports weie identified requiring modification. Thirty-five modifications have been completed with the remaining eight scheduled for completion by the end of the next refueling outage after July 24, 1981. Licensee also indicated that there are no major seismic related concerns which could potentially affect the operability of the AFW system during a seismic event.

\section{CONCLUS IONS}

The licensee's responses provided all the information that was explicitly requested by GL $81-14$. Based on the information, we conclude that the AFW system at Milstone Nuclear Power Station; Unit 2, is able to provide the safety-relaced function following a SSE to assure safe shutdown of the plant. Therefore, we 
recommend that no further action be initiated regarding upgrading of the AFW systems of this plant under NRC Multiplant Action C-14.

\section{REFERENCES}

1. D. G. Eisenhut, 'Multiplant Action Plan C-14; Seismic Qualification of Auxiliary Feedwater System," U. S. Nuclear Regulatory Commission, memorandum to H. R. Denton (February 20, 1981).

2. U. S. Nuclear Regulatory Comission, Generic Letter to all operating pressurized water reactor licensees, "Seismic Qualification of Auxiliary Feedwater System," (February 10, 1981).

3. W. G. Counsil, Northeast Nuclear Energy Company, letter to D. G. Eisenhut of U. S. Nuclear Regulatory Cormission, July 24, 1981.

4. R. A. Clark, USNRC, letter to W. G. Counsil of Northeast Nuclear Energy Company, "Requeat for Additional Information on Seismic Qualification of the Auxiliary Feedwater System, Millstone Nuclear Power Station, Unit 2," April 15, 1982.

5. W. G. Counsil, Northeast Nuclear Energy Company, letter to R A. Clark of USNRC, June $4,1982$. 


\section{SEISMIC QUALIFICATION OF AUXILIARY FEEDWATER SYSTEY TECHNICAL EVALUATION REPORT}

NORTH ANNA PONER STATION, UNITS 1 AND 2

\section{INTRODUCTION}

Since the accident at Three Mile Island, considerable attention has been focused on the capability of nuclear power plants to reliably remove decay heat. The NRC has recently undertaken Multiplant Action Plan C-14 "Seismic Qualification of AFW Systems,"I wich is the subject of this evaluation.

To implement the first phase of Action Plan C-14, the NRC issued Generic Letter No. 81-14 "Seismic Qualification of AFW Systems,"2 dated February 10, 1981, to all operating PWR licensees. This letter requested each licensee (1) to conduct a welkdown of nonseismically qualified portions of the AFW system and identify deficiencies amenable to aimple actions to improve seismic resistance, and (2) to provide design information regarding the seismic capability of the AFW system to facilitate NRC backfit decisions.

The livensee of North Anna Power Station, Units 1 and 2, responded with a letter dated July $16,1981,3$ and provided a supplemental response in a letter dated December $1, .1981 .4$

This report is a technical evaluation based on the information from the licensee's responses to $\mathrm{GL} 81-14$, including recomnendations for additional analysis and/or upgrading modification of this plant's AFW system.

\section{EVALUATION}

Information provided in the licensee's response include:

- Specification of the overall seismic capability of the AFW system.

- Description of methodologies and acceptance criteria for seismic design of the AFW system, which is determined to be seismically qualified to the SSE level by the licensee.

- Description of the AFW system boundary.

- Status of compliance with seismic related NRC Bulletins and Information Notices.

We have reviewed the licensee's responses, and a point-by-point evaluation of the licensee's responses against the Generic Letter's requirements as shown below.

\subsection{SEISMIC CAPABIIITY OF THE AFH SYSTEM}

The AFW system has been designed, constructed, and maintained to withttand a SSE utilizing methods and acceptance criteria consistent with 
that applicable to other safety-related systems in the plant. All areas of the AFW system (i.e., pumps/motors, piping, valves/actuators, power supplies, water source, instrumentation/control systems, and structures supporting and housing the AFW system) are seismically qualified to the SSE level.

The 1 icensee provided a description of the wethodologies and acceptance criteria used for seismic qualification of the AFw system, and referred to the applicable sections of the FSAR. The description includes seismic analysis methods, seismic input, load combinations, allowable stresses, qualification testing, and engineering evaluations performed.

Because the primary water source and supply path is seismically qualified, switchover to a secondary water source is not involved.

Information regarding the seismic capability of any alternate decay heat removal system is not required because the AFW system is fully seismically qualified.

Regarding the AFW system boundary, the licensee stated that one of the boundaries of North Anna's AFW system is the first isolation check valve outside of the containment in the steam generator feed lines. However, the postulated failure of this single valve in a line is founded by the analysis of a Major Rupture of a Main feedwater Pipe, contained in FSAR, Section 15.4.2,2. Based on this information, we conclude that the AFW system will be able to provide adequate feedwater to the unaffected steam generators for required decay heat removal in the event of a Major Rupture of a Main Feedwater Pipe and, hence, the deviation in the AFW system boundary requirement from the GL $81-14$ is acceptable.

The licensee stated that the AFW system was included within the scope of the seismic related NRC Bulletins 79-02,79-04,79-07,79-14, 80-11, and IE Information Notice $80-21$.

\subsection{WALKDOWN OF NONSEISMICALLY-QUALIFIED POKTION OF THE AFW SYSTEM}

A walkdown is not required because no lack of seismic quaification of the AFW system is indicated.

\section{CONCLUSIONS}

The inforwation contained in licensee's responses to GL $81-14$ is complete. The licensee stated that the AFW system boundary does not fully conform to the definitions of GL 81-14 and provided a justification of the deviation, which we conclude to be acceptable.

Based on the submitted information, we conclude that the AFW system at North Anna Power Station, Units 1 and 2, is fully seismically qualified and is able to provide the safety related function following a SSE. Therefore, we recommend that no further action be initiated regarding upgrading of the AFW system of this plant under NRC Multiplant Action Plan C-14.

\section{REFERENCES}

1. D. G. Eisenhut, "Multiplant Action Plan C-14; Seigmic Qualification of Auxiliary Feedwater System," U. S. Nuclear Regulatory Commisaion, memorandum to H. R. Denton (February 20, 1981). 
2. U. S. Muclear Regulatory Commission, Generic Letter to all operating pressurized water reactor 1 icensees, "Seismic Qualification of Auxiliary Feedwater System," (Pebruary 10, 1981).

3. R. H. Leasburg, Virginia Electric \& Power Co., letter to H. R. Denton of U. S. Nuclear Regulatory Comiosion, July 16, 1981 .

4. R. H. Leasburg, Virginia Electric \& Power Co., letter to H. R. Denton of U. S. Nuclear Regulatory Commission, December 1, 1981 . 


\section{SEISMIC QUALIFICATION OF AUXILIARY FEEDWATER SYSTEM TECHNICAL EVALUATION REPORT}

OCONEE NUCLEAR STATION, UNITS 1, 2, AND 3

\section{INTRODUCTION}

Since the accident at Three Mile Island, considerable attention has been focused on the capability of nuclear power plants to reliably remove decay heat. The NRC has recently undertaken Multiplant Action Plan C-14 "Seismic Qualification of AFW Systems,"l which is the subject of this evaluation.

To implement the first phase of Action Plan C-14, the NRC issued Generic Letter No. 81-14 "Seismic Qualification of AFW Systems,"2 dated February 10, 1981 , to all operating PWK licensees. This letter requested each licensee (1) to conduct a walkdown of nonseismically qualified portions of the AFW system and identify deficiencies anenable to simple actions to improve seismic resistance, and (2) to provide design information regarding the seismic capability of the AFW system to facilitate NRC backfit decisions.

The licensee of Oconee Nuclear Station, Units 1, 2, and 3, responded with a letter dated January $28,1982.3$ The licensee's response was found not to be complete and a Request for Additional Information was issued by the NRC, dated April 8, 1982.4 The licensee provided a supplemental response in a letter dated May 25, 1982.5

This report is a technical evaluation based on the information from the licensee's responses to GL $81-14$, including recomendations for additional analysis and/or upgrading modification of this plant's AFW system.

\section{EVALUATION}

Information provided in the licensee's response include:

- Specification of the overall seismic capability of the AFW system.

- Indentification of AFW system components that are currently nonseismically qualified for SSE.

- Discussion of levels of seismic capability of nonseismically-qualified components.

- Specification of overall seismic capability of the Standby Shutdown Facility (SSF) system which will serve as an alternate decay heat removal system.

- Description of methodologies and acceptance criteria for the seismic design of the SSF system, which is determined to be seismically qualified for the SSE level by the licensee.

- Description of the AFW and SSF system boundary.

- Status of compliance with seismic related NKC Bulletins and Information Notices.

- Additionally, schematic sketches of the AFW and SSP systems. 
- Additionally, identification of areas of modification of the AFW system that will be performed under the SSF project.

- Additionally, description of methodologies and acceptance criteria for seismically qualified components of the AFW system.

We have reviewed the licensee's responses, and a point-by-point evaluation of the licensee's responses against the Generic Letter's requirements as shown below.

\subsection{SEISMIC CAPABILITY OF THE AFW SYSTEM}

Except for those items identified in the following, the hFW system has been designed, constructed, and maintained to withstand a SSE utilizing methods and acceptance criteria consistent with that applicable to other safety-related systems in the plant. Presently, those items identified by the licensee as not being fully seismically qualified are evaluated below.

- Pump/Notors

- Piping

- Valves/Actuators
Portions of the turbine-driven pump oil system and oil cooling system, including the oil pumps and water cooling pumps do not have retrievable seismic documentation. However, we judge by experience that the pumps/motors possess a less than OBE level of seismic capacity. The portion of all connected branch piping beyond the first valve is currently nonseismically qualified. We believe that the AFW system piping is likely to possess an OBE level of seismic capacity.

(a) oil valves in the support system. However, the licensee indicated that credit for seismic design is not necessary because they are equipped with handwheels for manual operations. (b) Pneumatic control valves and their backup nitrogen bottles. However, the licensee indicated that these valves will fall open upon 108 of gas pressure or they can be bypassed by aligning the AFW flow through the main feedwater scartup line into the normal or AFW steam generator nozzles on either steam generator.

(c) Certain valves do not have retrievable seismic documentation. The licensee stated, however, that such valves were built to at least the ANSI B 31.1.0 criteria and were modeled into the stress analyses as 


\section{- $\quad$ Power Supp1ies}

- Water Source( $(B)$

- Initiation/Control Systems equivalent pieces of pipe for structural purposes. Based on the above information, we believe that the valves/actuators are likely to possess an DBE level of seismic capacity.

Power to the electric motor-opersted valves and pumps, except for the motor-driven AFW pumps and the lower pressure service water pumps, is currently nonseismically qualified. However, the iicensee stated that seismic design credit is not n.cessary for the power to the electric motor-operated valves because these valves can be manually operated with handwheels. We judge that the power supplies possess a less than OBE level of seismic capacity.

None

The control to the motor-operated valves other than those in the auto-initiation and auto-control of the AFW system is not seismically qualified. This includes the control to the branch line isolation valves off the main steam header and the electric motor-operated valves in the AFW suction and tischarge lines which are normally aligned for AFW operation but not normally required to operate. However, the licensee stated that no actuation is required of the motor-operated valves for the AFW flow and the valves will fail as-is upon loss of power. We therefore judge that the initiation/ control systems possess the capacity to withstand a SSE.

The turbine building is seismic Clags II. We therefore judge that the structures supporting or housing the AFW system components are capable of withstanding an $\mathrm{OBE}$.

Based on our evaluation described above, those areas of the AFW system judged not to possess a SSE seismic capability are identified below.

$\begin{array}{ll}- & \text { Pimps/Motor } \\ \text { - Piping } \\ \text { - Valves/Actuators } \\ \text { Power Supplies }\end{array}$

Less than OBE

$O B E$

OBE

Less than OBE 


$\begin{array}{ll}\text { - Water Sc:rce(s) } & \text { None } \\ \text { - Initiation/Control Systems } & \text { None } \\ \text { - Structures } & \text { OBE }\end{array}$

In Bumary, our evaluation indicated that the licensee's AFW system does not possess an overall seismic capability that can withstand a SSE.

Because the primary water source is seismically qualified for the SSE, a switchover to a seismically qualified secondary water source is not involved.

The Standby Shutdown Facility (SSF) system, being constructed to provide a dedicated separate train of auxiliary feedwater, will provide an alternaie decay heat removal system when it becomes operational. No procedure is available at this time to switch from the AFW syotem to the SSF syatem. Such procedure will be developed on a schedule commensurate with the SSF system starcup. The licensee did not. indicate the completion date of the new SSF sys tem.

The SSF systen is designed to withstand the SSE. Structures supporting or housing the SSF system components include the reactor building and auxiliary building and are seismic class $I$. The licensee provided a description of the methodologies and acceptance criteria used for seismic qualification of the SSF system, referring to applicable sections of the FSAR and licensee's letters of March 28, 1980; February 16, 1981; March 31, 1981; and April 13, 1981.

Regarding the AFW system boundary, all connected branch piping and crossover connections anong the three units are seismically qualified only through the firat valve. We judge that the AFW system boundary does not fully meet the regrirements defined in the Ceneric Letter.

Regarcin/3 the SSF system boundary, some small piping vents and drains, capped lines, cank vents, and a recirculation line from the diesel fuel oil storage tank either have only one normally closed valve or are seismically designed only through the first valve. He judge that the SSF system boundary coes not conform to the definition of boundary specified in the Generic fetter. Since the exiuting AFW system is not fully seismically qualified, we feal that this deviation needs to be evaluated and/or corrected in order to assure the required safety function of the SSF system.

The licensee stated that both the AFW and SSF systems were included within the scope of the seismic related NRC Bulletins 79-02, 79-04, 79-07, $79-14,80-11$, and IE Information Notice 80-21.

\subsection{WALKDOWN OF NONSEISMICALLY-QUALIFIED PORTION OF THE AFW SYSTLII}

The licensee stated that no walkdown was performed for the nonseismically-qualified items of the AFW system due to reliance on the SSF systen though the walkdown is requested by GL 81-14. We feel that a walkdown is required if the new SSF system does not become operational within $a$ reasonalbe period of ime. 


\subsection{ADDIT IONAL INFORMATION}

The licersee provided a schematic sketcin of the AFW and SSE systems including the water source(s), heat sink, sunction and diacharge piping, ancr mechanical equipment, and structures supporting and housing the AFW and SSF gystem items.

Additionally, licensee's respunses provided a description of the methodclogies and acceptance criteria that were used in the design of the seismically qualified portiors of the AFW system, by referring to the applicable sections in the FSAR.

The licensee identified the areas of the AFW systen where modification/ upgrade will be performed for the tie-in between the SSF and AWW systems. Because the construction of the SSF system is underway, the licensee steted that no additional modification to the AFW systew is necessary due to reliance upon the SSF system.

\section{CONCLUSTONS}

The information contained in 1 icensee's responses is complece. The licensea did not perform walkdown of tise curzently nonseismically-qualified areas of the AFW system because the SSF system, being under construction, is desigsed to withstand the SSE and to serve as the alternate decay heat removal system. The awitchover procedure from the AFW to the SSF aystem will be established commensurate with the startup operation of the SSF system. Both the AF! and SSF system brindaries do not fully moet the definition specified in GL $81-14$.

Based upon the submitted information, we conclude that the SW system foes not presently possess the seismic capability to withstand a SSE. The ability of the SSF system to perform the required safety function following the occurrence of a SSE is alsc in question besause the SSF system boundary does not fully conform to the boundary definition specified in GL $81-14$. In conclusion, we recommend that the KRC considers requiring the licensee (a) to submit the estimated completion date of the SSF system and perform a walkdown of the existing AFW system if it is determined that the SSF aystem will not becone operational within a reasonable period of time and (b) to evaluate and/or correct the deviation of the SSF system boundary in order to assure the required safety related func:ion.

\section{REEERENCES}

1. D. E. Eisenhut, "Multiplant Action Plan C-14; Seismic Qualification of Auxiliary Feedwater System," U. S. Nuclear Regulatory Comnission, memorandum to H. K. Denton (February 20, 1981).

2. U. S. Nuclear Regulatory Commission, Generic Letter to all operating pressurized water reactor licensees, "Seismir Qualification of Auxiliary Feedwater System," (February 10, 1981).

3. W, O. Parker, Jr., Luke Power Company, letter to H. R. Dentor. of U. S. Nuclear Regulatory Comission, January 28, 1982. 
4. J. F. Stolz, U. S. Muclear Regulatory Comision, letter to W. O. Parker, Jr., of Duke Power Company, "Request for Additional Information on Seiamic Qualification of the Auxiliary Feedwater System, Oconee Nuclear Station Units 1, 2, and 3, April 8, 1982.

5. W. 0. Parker, Jx., Luke Power Company, letter to H. R. Denton, U. S. Nuclear Regulatory Commision, May 25, 1982. 


\section{SEISHIC QUALIFICATION OF AUXILIARY FEEDWATER SYSTEM \\ TECHNICAL EVALUATION REPORT}

POINT BEACH NUCLEAR PLANT, UNITS 1 AND 2

\section{INTRODUCTION}

Since the accident at Three Mile Island, considerable attention has been focused on the capability of nuclear power plants to reliably remove decay heat. The NRC has recently undertaken Nultiplant Action Plan C-14 "Seismic Qualification of AFW systems," which is the subject of this evaluation.

To implement the first phase of Action Plan C-14, the NRC issued Generic Letter No. 81-14 "Seiamic Qualification of AFW Systems,"2 dated February 10, 1981 , to al1 operating PWR licensees. This letter requested each licensee ( 1 ) to conduct a walkdown of nonseismically qualified portions of the AFW system and identify deficiencies amenable to simple actions to improve seismic resistance, and $(2)$ to provide design information regarding the seismic capability of the AFW system to facilitate NRC backfit decisions.

The licensee of Point Beach Nuclesr Plant, Units 1 and 2, responded with a letter dated July 16, $1931 .{ }^{3}$ The licensee's response was found not to be complete and a Request for Additional Information (RAI) was issued by the NRC, dated January $25,1982.4$ The licensee provided a supplemental response in a letter dated May $4,1982.5$

This report is a technical evaluation based on the information from the licensee's responses to GL $81-14$, including recomendations for additional analysis and/or upgrading modification of this plant's AFW system.

\section{EVALUATION}

Information provided in the licensee's response include:

- Specification of the overall seismic capability of the AFW system.

- Identification of AFW system componente that are currently nonseismically qualified fur SSE.

- Sumnary of precedures for switchover to the eecondary water source and supply path.

- Diacussion of levela of seismic capability of nonseismically-qualified components.

- Description of the AFW eystem boundary.

- Status of compliance with seismic related NRC Bulletins and Information Notices.

- Additionally, schematic sketch of the AFW system.

- Additionally, description of methodologies and acceptance criteria for seismically qualified portions of the AFW system. 
- Additionally, results of walkdown of seimically qualified areas of the AFW syatem and identification of areas of modification/upgrade with proposed schedule to upgrade.

We have reviewed the licensee's responees, and a point-by-point evaluation of the licensee's responses against the Generic Letter's requiremeats as ahown below.

\subsection{SEISMIC CAPABILITY OF THE AFW SYSTEM}

Except for those items identified in the following, the AFW system has been designed, constructed, and maintained to withstand a SSE utilizing methods and acceptance criteria consistent with that applicable to other safety-related systems in the plant. Presently, those items identified by the licensee as not being fully seicmically qualified are evaluated below.

\section{- Pumps/Motors \\ - Piping}

\footnotetext{
- Initiation/Control Systems
}

None

Licensee has otated that branch piping Nos. 20 to 28 were not originally required to be seismic. Connections 20 and 21 go to the Unit 1 and 2 Condensers. Connection 22 is a 1.5 in. connection to the Waste and Blowdown Evaporator Distillate Processing System. Connection 23 is a 4-ij. connection to the heating boiler jeed pump. Connection 24 is a 2-in. diam connection riat provides a source of water to the turbine plant chemical addition tanks. Connection 25 is a 3-in. diam connection to the mixed bed demineralizer in the makeup water treatment system. Connections 26, 27 and 28 were not clearly identified in licensee 's response. Licensees' response did not discuss the seismic capability of these branch lines, therefore, we judge that they possess a less than OBE level of seismic capability.

None

None

The condensate storage tank of the primary water source is seismic Class II. However, a seiomic Class I secondary water and supply path, the service water system, is available and a manual switchover procedure exists.

None Except for the seismic Class I control building, other structures 
housing or supporting the AWW system including the turbine building, auxiliary building ouperstructure and the facade in containment building were not designed to seismic requirements. Licensee日' response did not discuss the seismic capability of these nonseismic Class I structures except that recently the turbine building has been analyzed for yeismic loading assuming the turbine building crane to be located above the control building and was found to be capable of withstanding a SSE. Classification needs to be made, however, that this is the worst loading condition for the turbine building in the presence of a seismic event. We therefore conclude that the structures in general have a less than OBE level of seismic capacity.

Based on our evaluation described above, those areas of the AFW system judged not to possess a SSE seinmic capability are identified below.

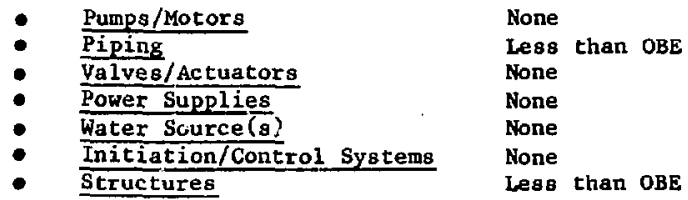

In summary, our evaluation indicates that the licensee's AFW syster does not poseess an overall seismic capability that can withstand a SSE.

The primary water source and supply path is not seismically qualified, therefore, switchover to the seismically qualified secondary water source and supply path is requized. The licensee stated that such procedure is available by warning the operator when the low level (20\% or $4 \mathrm{ft}$ ) on the condensate storage tank occurs. The operator then opens the auxiliary feedwater pump service water system suction valves following such a warning.

Seismic qualification information for any alternate decay heat removal system was not provided in the licensee's responses. This information was requested by GL $81-14$ if substantial lack of seismic qualification is indicated for the AFW system. Based on the information provided by the licensee we did not find that the licensee's AFW system has a SSE capebiliry. For the purpose of removing decay heat following a SSE, the 1 icensee needs to either reanalyze and/or modify ita AFW system, or to provioje an alternate decay heat removal system seisuically qualified to the SSE level and appropriate operating procedurea. 
Regarding the AFy boundary, the licensee's responses indicated that piping branch connections 6 through 28 do not comply with GL 81-14 boundary definitions because they do not have a second normally closed valve. Pipe connections 6 through 9 are outlet connections for the pump recirculation piping. Connections 10 through 13 were not clearly identified in licensee's response. Connections 14 through 19 are overflow, drain, and instrument connections on the Condensate Storage Tank. Connections 20 through 28 are described previously in page 3 of this report. The licensee atated that the AFW system was included within the scope of seismic related Bulletins 79-02, 79-04, 79-07, 79-14, 80-11, and IE Information Notice 80-21, except for part of the piping supports identified under IE 79-14 that will be upgraded by the end of June, 1982.

\subsection{WALKDOWN OF NONSEISMICALLY-QUALIF IED PORTION OF THE AFW SYSTEM}

A walkdown of the nonseismically-qualified areas of the AFW system is required, but has not been conducted.

\subsection{ADDIT IONAL INEORMATION}

The licensee provided schematic representation of the plant including structures, major AFW system components and piping, and showed sketches of piping in the IE Bulletin 79-14 program with identification of pipe sonnections. Also included are preliminary piping isometrics from the IE Bulletin 79-14 program.

Regarding the valves, additional information provided by the licensee stated that IE Bulletin 79-14 piping analyses did not analyze the valve itself, but as long as the acceleration level on the valve was less than $3 \mathrm{~g}$, the valve operator was considered acceptable, otherwise, the valve received additional evaluation.

For other items in the AFW system that are seismically qualified, the seismic qualification methodologies are given in the FSAR and are consistent with that applied to other safety-related systems in the plant.

A recent walkdown on seismically qualified items has identified the following deficiencies: (a) Main Piping: The 1.5 in. Db-3 recirculation pipe jor each of the four AFW pumps and the discharge pioing of each pump are not adequately supported. These deficiencies are plann $\because$ do be corrected, but no definite schedule is given. (b) Power Supplies: Seismic resistance of the battery racks in the Battery Room is questionable and will be upgraded. Supports for cable conduits in P3BA and P38B cubicles will also be upgraded. (c) Initiation/Control System: Conduits D01-2, 2-4001, 1-4000 and 1-4001 and conduits above panels D12, D13 and D14 do not have adequate supports. Clamps will be provided to overcome these deficiencies. Also, the four safeguard motor control centers ( $1 \mathrm{~B} 32,1 \mathrm{~B} 42,2 \mathrm{~B} 32$, and $2 \mathrm{~B} 42$ ) in auxiliary building are presently not anchored to the floor. Supports will be installed to secure these cabinets. Upgrading of most of the shove mentioned items identified in the recer: walkdown will be performed by the end of 1982 . 


\section{CONCLUSIONS}

The information contained in licensee's responses to GL $81-14$ is incomplete with regard to the seismic capacity of nonseismically-qualified piping and structures. The walkdown conducted by the licensee had beea performed for the seismically qualified items and did Jot cover the nonseismically-qualified branch connections and structures. Host of the deficiencies identified $a s$ a result of this walkdown will be upgraded by the end of June, 1982. The licensee also stated that the AFW system boundary does not fully conform to the definition specified in GL 81-14.

Based on the submitted information, we conclude that the AFW system does not provide a reasonable assurance to perform its required bsfety function following a SSE. Therefore, we recommend that the NRC corsiders requiring the licensee to provide a reanalysis and/or modification of the AFW syotem to acquire a SSE level of capacity.

\section{REFERENGES}

1. D. G. Eigenhut, "Multiplant Action Plan C-14; Seismic Qualification of Auxiliary Feedwater System," V. S. Nuclear Regulatory Comission, memorandum to H. R. Denton (February 20, 1981).

2. v. S. Nuclear Regulatory Commission, Generic Letter to all operating pressurized water reactor licensees, "Seismic Qualification of Auxiliary Feedwater System," (February 10, 1981).

3. C. W. Fay, Wisconsin Electric Power Company, letter to H. R. Denton of U. S. Nuclear Regulatory Comission, July 16, 1981.

4. R. A. Clark, U. S. Nuclear Regulatory Comission, letter to C. W. Fay of Wisconsin Electric Power Company, "Request for Additional Information on Seismic Qualification of the Auxiliary Feedwater System, Point Beach Nuclear Plant Units 1 and 2," January 25, 1982.

5. C. W. Fay, Wisconsin Electric Power Company, letter to H. R. Denton of

U. S. Nuclear Regulatory Commission, May 4, 1982. 


\section{SE ISMIC QUALIFICATION OF AUXILIARY FEEDWATER SYSTEM TECHNICAL EVALUATION REPORT}

PRAIRIE ISLAND NUCLEAR PLANT, UNITS 1 AND 2

\section{INTRODUCTION}

Since the accident at Three Mile Island, considerable attention has been focused on the capability of nuclear power plants to reliably remove decay heat. The NRC has recencly undertaken Multiplant Action Plan C-14 "Seismic Qualification of AFW Systems," which is the subject of this evaluation.

To implement the first phase of Action Plan C-14, the NRC issued Generic Letter No. 81-14 "Seismic Qualification of AFW Systems,"2 dated February 10, 1981, to all operating PWR licensees. This letter requested each licensee (1) to conduct a walkdown of nonseismically qualified portions of the AFW aystem and identify deficiencies amenable to simple actions to improve seismic resistance, and (2) to provide design information regarding the seismic capability of the AFW syotem to facilitate NRC backfit decisions.

The licensee of Prairie Island Nuclear Plant, Units 1 and 2, reaponded with a lecter dated July 14, 1981, 3 The licensee's response was found not to be complete and a Request for Additional Information (RAI) was issued by the NRG, dated April 5, 1982.4 The licensee provided a supplemental reoponse in a letter dated Kay 6, 1982.5

This report is a technical evaluation based on the information from the licensee's responses to $\mathrm{GL} 81-14$, including recomendations for additiona 1 analysis and/or upgrading medification of this plant's AFW system.

\section{EVALUATION}

Information provided in the licensee's response include:

- Specification of the overall seismic capability of the AFW system.

- Identification of AFW system components that are currently nonseigmically qualified for SSE.

- Description of procedure for switchover to a seismically qualified secondary water ource.

- Discussion of the levels of seisnic capability of the nonseismically-qualified components,

- Description of the AFW gysten boundary.

- Statur of compliance with seismic related NHC Bulletins and Information Notices.

- Results of walkdown of nonseismically-qualified areas.

- Additionally, description of methodologies and acceptance criteria for the seisinically qualified components. 
- Additionally, results of evaluation and walkdown of seismically qualified areas and areas outside of AFW system that have potential of damaging the AFW system in a SSE event.

We have reviewed the 1 icensee's responses, and a point-by-point evaluation of the licensee's responses against the Generic Letter' $B$ requirements as shown below.

\subsection{SEISMIC CAPABILITY OF THE AFW SYSTEM}

Except for those items identified in the following, the AFW system has been designed, constructed, and maintained to withstand a SSE utilizing methods and acceptance criteria consistent with that applicable to other safety-related systems in the plant. Presently, those items identified by the licensee as not being fully seismically qualified are evaluated below.

\section{- Pumps/Motors \\ - Piping}

\author{
None \\ (a) Four 2 in. cooling water branch \\ lines, which have not been \\ seismically analyzed. (b) All drain \\ piping to traps in auxiliary steam \\ Byatem, which have not been \\ seismically analyzed. (c) Most of \\ the primary wacer source piping are \\ laterally supported in north-south \\ direction only. Additional seismic \\ restraints in the east-weat direction \\ are required. The licensee stated \\ that in all areas where modeling and \\ analysis was required as part of the \\ AFW piping modification, analys is \\ work has been initiated and is \\ completed. Where analysia has shown \\ that additional supports are \\ required, installation drawings are \\ boing made and installation or \\ modification will commence as system \\ availebility and time allow. All \\ identified modificaíisne fould be \\ compleced prior to or during the \\ units 1 \& 21983 refueling outages. \\ Based on the above information, we \\ conclude that the piping has a \\ seisnic capability less than $\mathrm{OBE}$ but \\ will possess a SSE level of seismic \\ capability when the upgrading \\ modification is completed in timely \\ manner. \\ The licensee stated that oeismic \\ analysis, review and approval \\ documentation were not found in files \\ for certain VELAN valves. However it
}




\section{- $\quad$ Power Supplies}

- $\frac{\text { Initiation/Control Systems }}{\text { Structures }}$ was felt by the licensee that these valves were geismically qualified because they were purchased with design Class I seismic qualification as a specified requirement. He judge that valves/actuators have a SSE level of seismic capability. None

The condensate storage tank, as the primary water source, was designed to Class III and has not been analyzed for seismic loads. However, a seismic Class I secondary water source (the cooling water system) is available and a owitchover procedure exists. We therefore judge that the water sources are capable of withstanding a SSE.

None

None

Based on our evaluation described above, those areas of the AFW system judged not to possess a SSE seismic capability are identified below.

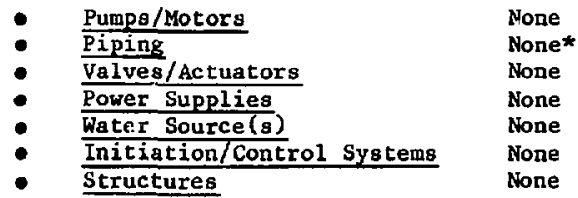

In summary, our evaluation indicates that the licensee's AFW oystem will possess an overall seismic capability that can withstand a SSE when the proposed upgrading modification is completed by the licensee.

The primary water source (condensate storage tank) is not seismically qualified. Also the primary supply path is not seismically qualified as mentioned in item (c) under the piping evaluation. Presently, the licensee has no plans for upgrading or modifications of these deficiencies. A seismic Class I secondary water source and a switchover procedure are presently available. The switchover is performed by opening one motor operated valve in each AFW pump suction piping. However, the secondary-water supply path is not fully seismically qualified because there are deficiencies in the four 2 in. branch lines mentioned in item (a) under the piping evaluation. The licensee has stated that they have plans to upgrade these secondary water paths as discussed under the piping evaluation.

* Currently less than OBE, but will be upgraded/modified. 
Additionally information regarding the seismic capability of any alternate decay heat removal system is not involved because the AFW aystem will have a SSE level of seismic capability.

Regarding the AFW system boundary, the licensee indicated that the boundary includes all connected branch piping up to at least one valve. The valve(s) in each branch line are either normally closed or capable of automatic or manual closure when the safety function is required. The AFw syster boundary also includes any portion of the branch piping beyond the aforementioned valve(s) up to the first structural anchor or equipment connection. Valving arrangements that do not fully conform to the definition givcn in the GL 81-14 were identified by the licensee as discussed below. (a) The auxiliary feedwater system includes portions of the main feedwater piping up to the first motor operated valve upatream of the AFW piping connection. (b) For piping from Vesign class I pump discharge to Auxiliary Feedwater pump suction and the ring header which provides a redundant path of nooling water supply to Units 1 and 2 , not all the connected branch piping have the second isolation valve. Branch lines with nominal pipe size of 4 in. and larger are all provided with valves capable of automatic closure with the exception of a supply line to the sprinkler system with a nominal pipe size of 4 in. In addition, branch 1 ines with thominal size smaller than $4 \mathrm{in}$. can be isolated only by manual closure of the valves. (c) The auxiliary steam system includes portions of the main steam system frow the steam generator up to the first isolation valve which is normally closed or capable of automatic closure. Based on the above information, we conclude that the AFW system boundary does not fully conform to the definition specified in the GL 81-14. We also believe that the deviation needs to be evaluated and/or corrected in order to assure the required safety function of the AFW system.

The licensee stated that the AFW system was included within the scope of seismic-related Bulletins 79-02, 79-04, 79-07 and 80-11. IE Bulletin 79-.14 is not completely satisfied as some portions of the piping system are still being reviewed for compliance. The licensee stated that the implementation of IE Information Notice $80-21$, which involves equipment qualification, could potentially result in modification of a broad range of electrical devices. They stated that in order to avoid duplication of effort, they p:efer to defer further action until the NRC comes up with definite rules on this issue.

\subsection{HALKDOWN OF NONSEISMICALLY-QUALIEIED PORTION OF THE AFW SYSTEM}

The licensee conducted a walkdown of the nongeismically-qualified areas of the ADW system, and identified deficiencies in the AFW system piping, as discussed below. (a) The modeling of the wall sleeve where the 30 in. diameter cooling wacer header pipes penetrate the screenhouse at Column Row $B_{1}$ may not be adequate. (b) Strength of floor anchor plates supporting cooling water strainers los. $11,12,21$, and 22 must be reviewed for increased loading conditions. The licensee stated that in all areas where sodeling and analysis was indicated, analysis work has been initiated ani in some areas were complete. Where analysis has shown that additional. supports are required, installation drawings are being made and installation or modification will start as system availability and time allow. All identified modifications will be completed during the Units 1 and 21983 refueling outages . 


\subsection{ADDITIONAL INFORMATION}

The licensee's reaponses provided a description of the methodologies, loading combinations and acceptance criteria that were used in the design of the seismically qualified portions of the AFW system. Licensees' consultant conducted an evaluation and a walkdown of the power supplies and initiation/ control systems, and identified the following deficiencies: (a) Power Supplies: One $4160 \mathrm{v}$ awitchgear cabinet needs anchor bolts to unload plug wells; several $480 \mathrm{~V}$ owitchgear cabinets need replacement of a missing bolt; the anchorage of motor control centers needs to be modified; batcery racks need design modifications and batteries need to be protected from ancillary equipment; certain panels, racks and cabinets may need stiffened supports ror which testing is required along with stiffening and redesigning the supports for the components for which the fundamental frequency is less than 6 Hz. (b) Initiation/Control Systems: Certain pressure indicators and cabinets may need improved mounting; control room panels may need protection from ancillary equipment; selected cabinets, racks, panels and local control switch for a motor-operated valve may need redesign or stiffening for which testing along with redesigning and stiffening of the supports may be required for components for which the fundamental frequency is less than $6 \mathrm{~Hz}$.

For those deficiencies in the power supplies and the initiation/control aystem where testing is required as the corrective measures, the licensee stated they are deferring any action pending on the NRC's issuance of a Rule and Regulatory Guide, which is expected in 1984. The remaining identified deficiencies in the power supplies and the initiation/control systems are under review by the licensee, and all modifications will be completed prior to or during the Units 1 \& 21983 refueling outages.

Additionally, the licensee also performed walkdown of the areas outside of the AFW system that could potentially damage the AFW system during a SSE. Deficiencies were identified, corrective actions were proposed or are to be identified, and the schedule will be consistent with the mechanical and piping syatem upgrade as mentioned previously. Results of this additional walkdown are gummarized below. (a) Attachments of electrical boxes 1185 and 1768 should be evaluated for adequacy. (b) HVAC ductworks in the turbine building and the auxiliary building require re-evaluation for seismic adequacy.

(c) Srall conduits resting on cooling water supply piping need resupporting. (d) Unit coolers in AFW pump room need evaluation and resupporting.

\section{CONCLUSIONS}

The information contained in licensee's responses to the GL $81-14$ is complete. The walkdown on nonseismically-qualified areas of the AFW system identified some deficiencies. The licensee stated that all the identified modifications of the AFW syotem will be upgraded prior to or during the refueling outages of Units 1 and 2 in 1983 . It is also noted that the licensee's AFW system boundary does not fully conform to the definition apecified in the GL 81-14. 
Based on the submitted information, we judge that the AFW syatem will provide a reasonable assurance to perform its required safety function following a SSE provided that the proposed upgrading modification is completed and the AFW boundary deviation is evaluated and/or corrected by the license. In conclusion, we recomend that the NRC considers requiring the licensee to evaluate and/or correct the AFW boundary deviation to asatre the required safety function of the AFW system following the occurrence of a SSE.

\section{REFERENCES}

1. D. G. Eisenhut, "Multiplant Action Plan C-14; Seiemic Qualification of Auxiliary Feedwater System," U. S. Muclear Regulatory Commiasion, memorandum to H. R. Denton (February 20, 1981).

2. U. S. Nuclear Regulatory Commission, Generic Letter to all operating presaurized water reactor licensees, "Seismic qualification of Auxiliary Feedwater System," (February 10, 1981).

3. L. 0. Meyer, Northern States Power Company, Letter to the Director of v. S. Nuclear kegulatcry Commission, July $14,1981$.

4. v. S. Nuclear Regulatory Commission, telescopy to I 0 , Meyer of Northern States Fower Company, "Request for Additional Information on Seismic Qualification of the Auxiliary Feedwater System, Prairie Island Nuclear Plant, Units 1 \& 2," April 5, 1982.

5. L. 0. Meyer, Narthern States Power Company, Letter to the Director of U. S. Nuclear Regulatory Commission, May 3, 1982. 


\section{SE ISMIC QUALIFICATION OF AUXILIAKY FEEDWATER SYSTEM TECHNICAL EVALUATION REPORT}

RANCHO SECO NUCLEAR PLANT, UNIT 1

\section{INTKODUCTION}

Since the accident et Three Mile Island, considerable attention has been focused on the capability of nuclear power plants to reliably remove decay heat. The NRC has recently undertaken Multiplant Action Plan C-14 "Seismic Qualification of AFW Syatems,"1 which is the subject of this evaluation.

To implement the first phase of Action Plan C-14, the NRC issued Generic Letter No. 81-14 "Seismic Qualification of AFW Systems,"2 dated February 10, 1981 , to all operating PWR 1 icensees. This letter requested each licensee ( 1 ) to conduct a walkdown of nonseismically qualified portions of the AFW system and identify deficiencies amenable to simple actions to improve seismic resistance, and (2) to provide design information regarding the seismic capability of the AFW syotem to facilitate NRC backfit decisions.

The licensee of Rancho Seco Kuclear Plant, Unit 1, responded with letters dated July 17 and October 14, 1981.3,4 The licensee's response was found not to be complete and a laquest for Additional Informetion (RAI) was issued by the NRC, dated May 7, 1982.5 The licensee provided e supplemental response in a letter dated July $9,1982.6$

This report is a technical evaluation based on the infocmation from the licensee's responses to GL $81-14$, including recomendations for additional analysis and/or upgrading modification of this plant's AFW system.

\section{EVALUATION}

Information provided in the licensee's response include:

- Specification of the overall seismic capability of the AFW system.

- Identification of AFW system components that are currenty nonseismically qualified for SSE.

- Discussion of levels of seismic capability of nonseismically-qualified components.

- Description of the AFW system boundary.

- Status of compliance with seismic related NRC Bulletins and Information Notices.

- Additionally, schematic sketch of the AFW system.

- Additionally, description of methodologies and acceptance criceria for seismically qualified components.

- Additionally, proposed modification of the seismically qualified areas of the AFW system. 
We have revieved the 1 icensee's responses, and a point-by-point evaluation of the licensee's responses against the Generic Letter's requirements as shown below.

\section{$2: 1$ SEISMIC CAPABILITY OF THE AFW SYSTEM}

Except for those items identified in the following, the AFW system has been designed, constructed, and maintained to withstand a SSE $\lrcorner$ tilizing methods and acceptance criteria consistent with that applicable to other safety-related systems in the plant. Presently, those items identified by the licensee as not being fully seimically qualified are evaluated below.

\begin{tabular}{ll} 
- Pumps/Motors \\
- \\
Viping \\
\hline
\end{tabular}

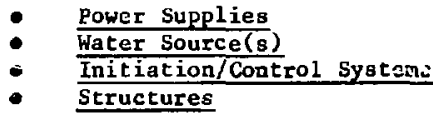

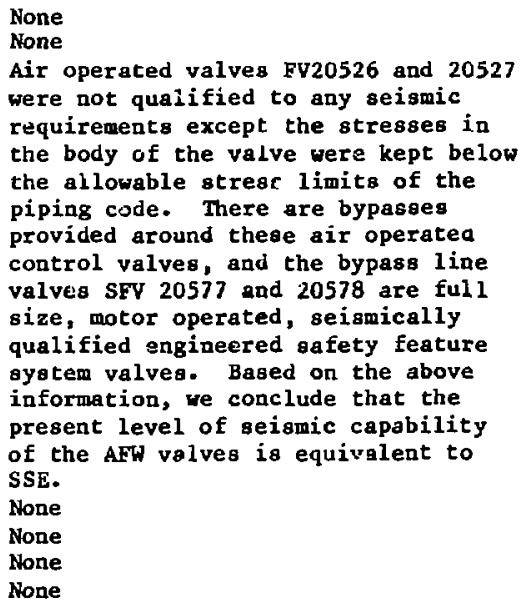

based on our evaluation described above, those areas of the AFW system judged not to possess a SSE seismic capability are identified below.

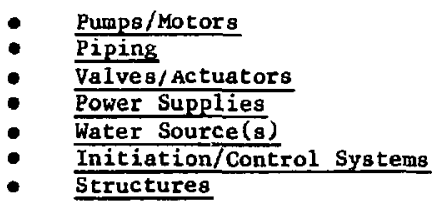

In summary, our evaluation indicated that the licensee's AFW system possesses an overall seismic capability that can wichstand a SSE.

Because the pridary water source and supply path are seismically qualified, switchover to a secondary water source is not involved. In addition, information regarding the seismic capability of any alternate decay 
heat removal aystem is not required because the AFW aystem is fuliy seismically qualified.

Regarding the AFW system boundary, the licensee stated the branch lines have been seismically qualified up to the point of three orthogonal restraints. However, the schematic aketch of the AFW system indicated that some of the branch connections do not have the second valve which is normal1: closed or capable of autnmatic closure. We therefore conclude that the AFW system boundary does not fully meet the requirements of the GL 81-14.

The licensee stated that the AFW syatan was included within the scope of the seismic related NRC Bulletins 79-02, 79-04, 79-07, 79-14, 80-11, and IE Information Notice 80-21.

\subsection{WALKDOWN OF NONSEISMICALLY-QUALIEIED PORTION OF THE AFW SYSTEM}

A walkrown is not required because we found that no lack of seismic qualification of the AFW syaten was indicate.

\subsection{ADDITIONAL INFORMATION}

The licensee provided a schematic sketch of the AFW system including che water sources, heat sink, suction and discharge piping, major mechanical equipment, and structures supporting and housing the AFW system items.

Additionslly, licensee's responses provided a description of the methodologies, loading combinations and acceptance criteria that were used in the design of the seismically qualified portions of the AFW system. They also referred to the appropriate sections of the FSAR.

The licensee also provided the following information on planned modification/upgrade related to, but not as a direct result of the GL 81-14. The licensee is currently modifying sections of the auxiliary feedwater line inside containment near the steam generators. This modification involves providing six inlet nozzles to the steam generators instead of one. The piping will be reanalyzed and because of added flexibility of the inlet header, rigid aupports and snubbers will be added to seismically qualify the piping.

\section{CONCLUSIONS}

The information contained in licensee's responses to the GL 81-14 is complete. Based on the submitted information, we conclude that the AFW system provides a reasonable assurance to perform its required safety function following a SSE, except that the AFW system boundary does not fully conform to the definition given in the GL 81-14. Therefore, we recommend that no further action be initiated regarding the need of modification/upgrading of the AFW system of this plant under NRC Multiplant Action Plan C-14. 
1. D. G. Eisenhut, "Multiplant Action Plan C-14; Seiomic Qualification of Auxiliary Feedwater System," v. S. Nuclear Regulatory Comission, memorandur to I. R. Jenton (Feituary 20, 1981).

2. U. S. Nuclear Regulatory Conmission, Generic Letter to all operating pressurized water reactor licensees, "Seismrc qualification of Auxiliary Feedwater Systam," (February 10, 1981).

3. J. J. Mattimoe, Sacramento Municipal Utility Discrict, letter to D. G. Eisenhut of U. S. Nuclear Regulatory Commission, July 17, 1981.

4. W C. Walbridge, Sacramento Kunicipal Utility District, letter to D. G. Eisenhut of U. S. Nuclear Regulatory Comnission, October 14, 1981.

5. U. S. Nuclear Regulatory Commission, letter to Sacramento Municipa1 Utility District, "Request for Additional Information on Seismic Qualification of the Auxiliary Feedwater System, Rancho Seco Muclear Generating Station Unit 1," May 7, 1982.

6. J. J. Mattimoe, Sacramento Municipal Uiility District, letter to J. F. Stolz of U. S. Nuclear Regulatory Commission, July 9, 1982. 


\section{SEISMIC QUALIFICATION OF AUXILIARY FEEDWATER SYSTEM TECHNICAL EVALUATION REPORT}

\section{H. B. ROBINSON STEAM ELECTRIC PLANT, UNIT 2}

\section{INTRODUCTION}

Since the accident at Three Mile Island, considerable attention has been focused on the capability of nuclear power plants to reliably remove decay heat. The NRC has recently undertaken Multiplant Action Plan C-14 "Seismic Qualification of AFW Sygtems,"

To implement the tirst phase of Action Plan C-14, the NRC issued GL 81-14 to all operating PWK 1 icensees, "Seismic Qualification of AFW Systems" dated February 10, 1981.2 This letter requested that each licensee (1) conduct a walk isw of nonseismically-qualified portions of the AFW syotem and identify deficlencies amenable to simple actions to improve seismic resistance and (2) provide design information regarding their specific AFW system seismic capabilities to facilitate NRC backfit decisions.

The licensee of $\mathrm{H}$. B. Robinson Steam Electric Plant, Unit 2, responded with a letter dated December $31,1981.3$ The licensee's response was found not to be complete and a Request for Additional Information (KAI) was issued by the NRC, dated July $22,1982.4$ The licensee provided a supplemental response in a letter dated August $20,1982.5$

This report is a technical evaluation based on the information from the 1 icensee's responses to GL $81-14$, including recommendations for additional analysis and/or upgrading modificatioli of this plant's AFW system.

\section{EVALUATION}

Information provided in the licensee's response include:

- Specification of the overall seismic capability of the AFW system.

- Description of methodologies and acceptance criteria for seimmic design of the AFW system, which is determined to be seismically qualified to the SSE level by the licensee.

- Description of the afW system boundary.

- Status of compoliance with seismic related NRC Bulletins and Information Notices.

- Additionally, schematic sketch of the AFW gystem.

We have reviewed the licensee's responses, and a point-by-point evaluation of the licensee's responses against the Generic Letter's requirements as shown below. 
The AFW system has been designed, constructed, and maintained to withstand a SSE utilizing methods and acceptance criteria consistent with that applicable to other safety-related systems in the plant. All areas of the AFH system, i.e., pumps/motors, piping, valves/actuators, power supplies, water source, initiation/control systems, and structures supporting and housing the AFW system, are seismically qualified to the SSE level.

The licensee provided a description of the weihodologies and acceptance criteria used for seismic qualification of the AFW system, and referred to the applicable sections of the FSAR. The description includes seismic analysis methods, seismic input, load combinations, allowable stresses, qualification testing, and engineering evaluations performed.

The condensate storage tank is the primary water supply and it is seismic class I. Switchover to a secondary water supply, therefore, is not involved. Additionally, the licensee indicated that there are a nonseismic Class I backup water supply, the well water system, and a seiamic class I backup water supply, the service water system. The licensee indicated that the procedure which would be followed to enable a transfer, if required, from the primary to the secondary water sources is outlined in the plant emergency instructions $E I-5$ and EI-6.

Additional jnformation regarding the seismic capability of any alternate decay heat removal system is not required because the AFW system currently is fully seismically qualified for the SSE.

Regarding the AFW system boundary, the licensee's responses indicated that, due to a restriction in the number of node points that could be modeled in one computer run utilizing the codes in existence at the time of the original analysis, specific guidelines for modeling of the branch line connections to the AFW system did not exist. During licensee's IE Bulletin 79-14 analysis, the additional effects of branch line loading were reviewed on a case-by-case basis and were judged to be insignificant. However, the licensee's responses did not clarify whether (a) the branch lines have been seismically analyzed and qualified up to a point of three orthogonal restraints in order to assure the structural incegrity of the branch lines, and (b) all branch lines have a second valve normally closed or capable of automatic closure when safety function is required. Therefore, it is not clear to us whether the AFW system boundary fully conforms to the definitions given in the GL 81-14.

The 1 icensee stated that the AFW system was included within the scope of the seismic related NRC Bulletins 79-02, 79-04, 79-07, 79-14, 80-11. The licensee is currently evaluating the adequacy of anchorage and support of safety related electrical equipment as described in IE Information Notice 80-21. As part of this analysis the adequacy of the seismic qualification of electrical cables and motor control centers will be assessed. The licensee steted that the evaluation is scheduled to be completed by the end or 1982 . 


\subsection{WALKDOWN OF NONSE ISMICALLY-QUALIFIED PORTION OF THE AFW SYSTEM}

A walkdown is not required because no lack of seismic qualification of the AFW system is indicated.

\subsection{ADDI TIONAI, INRORHATION}

The licensee provided a schemstic sketch of the AFW system including the water source $(8)$, heat sinks, suction and discharge piping, major mechanical equipment, and structures housing and supporting the AFW system items.

\section{CONCLUSTONS}

The information contained in licensee's responses to GL 81-14 is complete except that it did not clarify whether the AFW system boundary fully conforms to the definitions specified in GL 81-14.

Based on the submitted information, we conclude that the AFW syacem is fully seismically qualified and is able to provide the safety related function following a $\$ S E$ assuming that the AFW system boundary currently fully conforms to the boundary definitions specified in GL BI-14. Therefore, we recommend that no further action be initiated regarding upgrading of the AFW system of this plant under NRC Multiplant Action Plan C-14.

\section{REFERENCES}

1. D. G. Eisenhut, 'Hultiplant Action Plan C-14; Seismic Qualification of Auxiliary Feedwater System," U. S. Nuclear Regulatory Commission, memorandum to H. R. Denton (February 20, 1981).

2. U. S. Nuclear Regulatory Commission, Generic Letter to all operating pressurized water reactor licensees, "Seismic Qualification of Auxiliary Feedwater System," (February 10, 1981).

3. S. R. Zimmerman, Carolina Power \& Light Company, letter to D. G. Eisenhut of U. S. Nuclear legulatory Comission, December 31, 1981.

4. U. S. Nuclear Regulatory Commission, letter to Carolina Power \& Light Company, "Request for Additional Information on Seismic Qualification of the Auxiliary Feedwater System, H. B. Robinson Steam Electric Plant, Unit 2," July 21, 1982 .

5. S. R. Zimmerman, Carolina Power \& Light Company, letter to S. A. Varga of U. S. Nuclear Regulatory Commission, August 20, 1982. 


\section{SEISMIC QUALIFICATION OF AUXILTARY FEEDWATER SYSTEM TECHNICAL EVALUATION KEPORT}

SALEM NUCLEAR PLANT, UNITS 1 AND 2

\section{IN'CRODUCTION}

Since the accident at Three Mile Island, considerable attention has been focused on the capability of nuclear power plants to reliably remove decay heat. The NRC has recently undertaken Multiplant Action Plan C-14 "Seismic Qualification of AFW Systems," "l wich is the subject of this evaluation.

To implement the first phase of Action Plan C-14, the NRC issued Generic Letter No. 81-14 "Seismic Qualification of AFW Systems," dated February 10, 1981 , to all operating PWR licenseer. This letter requested each licensee (1) to conduct a walkdown of nonseismically qualified portions of the AFW system and identify deficiencies amenable to simple actions to improve seismic resistance, and (2) to provide design information regarding the seislic capability of the AFW system to facilitate NRC backfit decisions.

The licensee of Salem Nuclear Plant, Unica 1 and 2, responded with a letter dated August $11,1981.3$ The licensee's response was found not to be complete and a Request for Additional Information was issued by the NRC, dated January $7,1982.4$ The licensee provided a supplemental response in a letter dated March $1,1982,5$

This report is a technical evaluation based on the information from the licensee's responses to GL $81-14$, including recommendations for additions 1 analysis and/or upgrading modification of this plant'a AFW system.

\section{EVALUATION}

Information provided in the licensee's response include:

- Specification of the overall seismic capability of the AFW system.

- Description of methodologies and acceptance criteria for seismic design of the AFW system, which is determined to be seismically qualified to the SSE level by the licensee.

- Description of the AFW system boundary.

- Status of compliance with seismic related NRC Bulletins and Information Notices.

- Additionally, a schematic sketch of the AFW system.

- Additionally, proposed messures to protect two valves that are part of the AFW system boundary.

We have reviewed the licensee's responses, and a point-by-point evaluation of the licensee's responses against the Generic Letter's requirements as shown below. 


\section{I SEISMIC GAPABILITY OF THE AFW SYSTEM}

The AFW system has been designed, constructed, and maintained to withstand a SSE utilizing methods and acceptance criteria consistent with that applicable to other safety-related systems in the plant. All areas of the AFW system (i.e., pumps/motors, piping, valves/actuators, power supplies, water source, instrumentation/control systems, and structures supporting and housing the AFW system) are seismically qualified to the SSE level.

The licensee provided a description of the methodologies and acceptance criteria used for seismic qualifications of the AFW system, and referred to the applicable sections of the FSAR. The description includes seismic analysis methods, seismic input, load combinations, allowable stresses, qualification testing, and engineering evaluations performed.

A switchover procedure to a secondary water source is not involved because the primary water source and supply path is seismically qualified.

Information regarding the seismic capability of any alternate decay heat removal oystem is not required because the AFW gystem is fully seismically qualified. Regarding the AFW system boundary, licensee's responses indicated that valves ( $1 A F 71$ ) and $(1 A F 72)$ are not anchored with three orthogonal restraints. However, these valves are anchored to the Seismic Category I auxiliary building wall, and a stress review performed by the licensee showed that the anchors meet the intent of the AFW system boundary definition given in the Generic Letter. We therefore conclude that the AFW system boundary conforms to the definition in the Generic Letter.

The licensee stated that the AFW system was included within the scope of seismic-related Bulletins 79-02, 79-04,79-07, 79-14 and 80-11. IE Information Notice 80-21 was not mentioned in licensee's responses. However, a detailed review performed by the licensee showed that all electrical and control equipwent are fully seismically qualified, and further clarificacion is provided in the information provided by the licensee to the NRC Seismic Qualification Review Team. We conclude that the AFW system meets the incent of Information Notice 80-21.

\subsection{WALKDOWN OF NONSEISMICALLY-QUALIFIED PORTION OF THE AFW SYSTEM}

A walkdown is not required because no lack of seismic qualification of the AFW system is indicated.

\subsection{ADDITIONAL INFORMATION}

The licensee provided a schematic sketch of the AFW system including the water source(s), heat sinks, suction and discharge piping, major mechanical equipment: and 8 tructures housing and supporting the AFW system items.

Additionally, the licensee indicated that a protective steel structure will be provided off the Seismic Category I wall of the auxiliary building to which valves (1AF71) and (1AF72) are anchored. This new steel structure will also 
incorporate seismic guides for additional protection of these valves, with the existing anchor serving as an axial restraint in addition to its original function.

\section{CONCLUS IONS}

The licensee's responses provided all the information that was explicitly requested by the Generic Letter. Based on this information, we conclude that the AFW systems at the Salem Nuclear Plant, Units 1 and 2, will be abie to provide the safety- related function following a SSE to assure safe shutdown of the plant. Therefore, we recommend that no further action be initiated regarding upgrading of the AFW systems of these plants under NkC Multiplant Action Plant C-14.

\section{REFERENCES}

1. D. G. Eisenhut, "Multiplant Action Plan $0-14$; Seismic Qualification of Auxiliary Feedwater System," U. S. Nuclti Regulatcry Commission, memorandum to H. R. Denton (February 20, 4981 ).

2. U. S. Nuclear Regulatory Commission, Generic Letter to all operating pressurized water reactor licensees, "Seismic Qualification of Auxiliary Feedwater System," (February 10, 1981).

3. R. L. Mittl, Public Service Electric and Gas Company (PSEG), letter to

S. A. Varga of U. S. Nuclear Regulatory Commission, August 11, 1981.

4. S. A. Varga, USNRC, letter to R. L. Mittl of PSEG, "Request for Additional Information on Seismic Qualification of the Auxiliary Feedwater System, Salem Nuclear Generating Station, Units 1 and 2," January $7,1982$.

5. E. A. Liden, PSEG, letter to S. A. Varga of USNRC, March 1, 1982. 


\section{INTRODUCTION}

Since the accident at Three Mile Island, considerable attention has been focused on the capability of nuclear power plants to reliably remove decay heat. The NRC has recently undertaken Multiplant Action Plan C-14 "Seismic Qualification of AFW Systems,"I which is the subject of this evaluation.

To implement the first phase of Action Plan C-14, the NRC issued GL 81-14 to all operating PWR licensees, "SEismic Qualification of AFW Systems" dated Feoruary 10, 1981.2 This letter requested that each licersee (1) conduct a walkdown of nonseismically-qualified portions of the AFW system and identify deficiencies amenable to simple actions to improve seisinic resistance and (2) provide design information regarding their specific AFW system seismic capabilities to facilitate NRC backfit decisions.

The licensee of St. Lucie, Unit 1 , responded with a letter dated September 18, 1981.3 The licensee's response was found not to be complete and a Request for Additional Information (RAI) was issued by the NRC, dated April 2, 1982.4 The licensee provided a supplemental $r$ ssponse in a letter dated May 6, 1982.5

This report is a technical evaluation based on the information from the licensee's responses to GL $81-14$, including recommendations for additional analysis and/or upgrading modification of this plant's AFW system.

\section{EVALUATION}

Information provided in the licensee's response include:

- Specification of the overall seismic capability of the AFW system.

- Identification of currently nonseismically-qualified components of the AEW system.

- Discussion of the levels of seismic capabil ty of the nonseismically-qualified AFW system components.

- Description of the AFW system boundary.

- Status of compliance with seismic related NRC Bulletins and Information Notices.

- Results of walkdown of nonseismically-qualified portions of the AFW system.

- Additionally, description of methodologies and acceptance criteria for the seismically qualified components. 
- Additionally, results of walkdown performed for the anchorages/ supports for all Class IE electrical equipment.

We have reviewed the licensee's responses, and a point-by-point evaluation of the licensee's responses against the Generic Letter's requirements as shown below.

\subsection{SEISMIC CAPABILITY OF THE AFW SYSTEM}

Except for those items identified in the following, the AFW system has been designed, constructed, and maintained to withstand a SSE utilizing methods and acceptance criteria consistent with that applicable to other safety-related systems in the plant. Presently, those items identified by the licensee as not being fully seismically qualified are evaluated below.

$\begin{array}{ll}\text { - } & \text { Pumps/Motors } \\ \text { - Piping } & \frac{\text { Valves/Actuators }}{\text { Power Supplies }} \\ \text { - Water Source(s) } & \frac{\text { Initiation/Contro1 Systems }}{}\end{array}$

- Structures

\begin{abstract}
None
None

None

None

None

(a) Local gauges are not seimically qualified but the licensee stated that they are not essential for safety system operation. (b) The control grade automatic initiation circuitry, installed as a post-TMI modification, is not seismically qualified but the licensee stated that it would be upgraded to safety grade and seimic Category I during their outage in September 1981. We conclude that the initiation/control systems possesses a SSE level of seismic capability upon completion of the upgrade of the control grade automatic initiation circuitry. The conduit supports and mounting of certain electrical boxes were not qualified by rigorous analysis. However, the licensee inspected the above items in the field. They indicated in their response letter that this inspection verified that, in general, the support systems have conservative support spans and were installed in accordance with National Electrical Code Standards using standard comercially available otrut material, clamps, U-bolts, and various steel shapes, in conjunction with ANSI C80.1 rigid steel conduit. This level of design for
\end{abstract}


miscellaneous electrical component supports is consistent with industry practices for plants of the St. Lucie Unit 1 era. The 1 icensee also stated that these support designs and materials are used universally throughout the nuclear and fossil power plant field as well as other industries and were considered to have adequate seismic resistance at the time of installation. Also, the licensee indicated that industry tests on cable tray/conduit support assemblies based on worst case models indicated that systems supported by commercial grade components similar to those used at St. Lucie Unit 1 remained functional after being subjected to tests which simulated earthquake conditions. In their best judgment, the 1 icengee believed that the system would remain functional after a SSE. In conclusion, we judge that the conduit supports and mounting of certain electrical boxes possess a SSE level of seismic capacity.

Based on our evaluation described above, those areas of the AFW system judged not to possess a SSE seismic capability are identified below.

$\begin{array}{ll}\text { - Pumps/Motors } & \text { None } \\ \text { - } & \text { Niping } \\ \text { - } & \text { None } \\ \text { - Power Supplies } & \text { None } \\ \text { - } & \text { Nater Source(s) } \\ \text { Initiation/Control Systems } & \text { None } \\ \text { Structures } & \text { None } \\ \text { None }\end{array}$

In summary, our evaluation indicated that the AFW system at St. Lucie, Unit 1 , possesses an overall level of seismic capability that can withstand a SSE.

Because the primary water source and supply path is seismically qualified, switchover to a secondary water source is not involved. Information regarding the seismic capability of any alternate decay heat removal system is not required because the AFW system will have a SSE level of seismic capability upon the completion of the ongoing upgrade of the initiation/control systems.

Regarding the AWW system boundary, 1 icensee indicated that there is no branch piping in the flowpath which is required to be isolated in order to perform the AFW system function. There are no other branch piping connections 
to the AFW system. Only normal small bore vents, drains and instrument taps all with root valves, are provided as an integral part of the AFW system piping. These portions were seismically analyzed with the AFW system piping to meet seimic Category I requirements. Therefore, we conclude that the $A F W$ system boundary fully conforms to that required by the Generic Letter.

The licensee stated that the AFW system was included within the scope of the seismic related NRC Bulletin 79-02,79-04,79-07,79-14, 80-11 and is Information Notice 80-2l.

\subsection{WALKDOWN OF NONSEISMICALLY-QUALIFIED PORTION OF THE AFW SYSTEM}

A field inspection was conducted covering all system components that could not be readily qualified by existing documentation. These items consisted of nonseismically-qualified miscellaneous conduit and electical box supports. The licensee indicated that the as-built support system has considerable seismic resistance, and in their best engineering judgment the licensee believed that the system would remain functional following a SSE.

\subsection{ADDITIONAL INFORMATION}

The licensee provided information on the methodologies and acceptance criteria that were used in the seismic design of the seismically qualified portions of the AFW system.

Additionally, licensee decided to extend the inspection and review of electrical equipment support/anchorage to include all major class IE components for tise balance of safety related systems. All major electrical equipment anchorages and cable tray supports were found to be satisfactory.

\section{CONCLUSIONS}

The information contained in licensee's responses to GL $81-14$ is complete. The licensee conducted a waikdown to cover all nonseismically-qualified portions of the AFW system and did not find any deficiencies. In addition, we conclude that the AFW system boundary fully conforms to the boundary definition specified in the Generic Letter.

Based on the submitted information, we conclude that the AFW system provides a reasonable assurance to perform its reçired safety function following the occurrence of a SSE upon completion of the ongoing upgrade of the initial/control systems. Therefore, we recommend thet no further action be initiation regarding re-analysis and/or modification of the AFW system of St. Lucie under NRC Multiplant Action $\mathrm{C}-14$.

\section{REFERENCES}

1. D. G. Eisenhut, "Multiplant Action Plan C-14; Seismic Qualification of Auxiliary Eeedwater System," U. S. Nuclear Regulatory Comission, memorandum to H. R. Denton (February 20, 1981).

2. U. S. Nuclear Regulatory Comission, Generic Letter to all opirating pressurized water reactor licensees, "Seismic Qualification of Auxiliary Feedwater Systen," (February 10, 1981). 
3. R. E. Uhrig, Florida Power and Light Company, Letter to D. G. Eisenhut of v. S. Nuclear Regulatory Comission, September 18, 1981.

4. R. A. Clark, USNRC, letter to R. E. Uhrig of Florida Power and Light Company, "Request for Additional Information on Seismic Qualification of the Auxiliary Feedwater System, St. Lucie Unit 1," Apri.1 2, 1982.

5. K. E. Unrig, Florida Power and Light Company, Letter to R. A. Clark of USNKC, May 6, 1982. 


\section{SEISMIC QUALIFICATION OF AUXILIARY FEEDWATER SYSTEM TECHNIGAL EVALUATION REPORT}

SURRY NUCLEAR PLENT, UNITS 1 AND 2

\section{INTRODUCTION}

Since the accident at Three Mile Island, considerable attention has been focused on the capability of nuclear power plants to reliably remove decay heat. The NRC has Iecently undertaken Multiplant Action Plan C-14 "Seismic Qualification of AFW Systems," which is the subject of this evaluation.

To implement the first phase of Action Plan C-14, the NRC issued Generic Letter No. 81-14 "Seismic Qualification of AFW Systems,"2 dated February 10, 1981 , to all aperating PWR licensees. This letter requested each licensee (1) to conduct a walkciown of nonseismically qualified portions of the ArW syscem and identify deficiencies amenable to simple actions to improve seismic resistance, and (2) to provide design information regarding the seismic capability of the AFW system to facilitate NRC backfit decisions.

The licensee of Surry Naclear Plant, Units 1 and 2, responded with a letter dated July $16,1981.3$ The licensee's response was found not to be complete and a Request for Additional Information (RAI) was issued by the NRC, dated January 6, 1982.4 The licensee provided a supplemental response in a letter dated February $12,1982.5$

This report is a technical evaluation based on the information from the licensee's responses to GL 81-14, including recommendations for additional analysis and/or upgrading, modification of this plant's AFW system.

\section{EVALUATION}

Information provided in the licensee's response include:

- Specification of the overall seismic capability of the AFW system.

- Description of methodologies and acceptance criteria for the AFW system, which is determined to be seismically qualified to the SSE level by the licensee.

- Status of compliance with seismic related NRC Bulietins and Information Notices.

- Schematic sketch of the AFw system.

We have reviewed the licensee's responses, and a point-by-point evaluation of the licensee's responses against the Generic Letter's requirements as shown below. 


\subsection{SEISMIC CAPABILITY OF THE AFW SYSTEM}

The AFW system has been designed, constructed, and maintained to withstand a SSE utilizing methods and acceptance criteria consistent with that applicable to other safety-grade systems in the plant. All azeas of the AFW system (i.e., pumps/motors, piping, valves/actuators, power supplies, water source, instrumentation/control systems, and structures housing and supporting the AFW system) are seismically qualified to the SSE level.

The licensee provided a description of the methodologies and acceptance criteria used for seismic qualification of the AFW system by referring to the applicable sections of the FSAR. The description includes seismic analysis methods, seismic input, load combinations, allowable stresses, qualification testing, and engineering evaluations performed.

A switchover procedure to a secondary water source is not involved because the primary water source and supply path is seismically qualified.

Information regarding the seismic capability of any alternate decay heat removal system is not required because the AFW system is fully seismically qualified.

legarding the AFW system boundary, the licensee's responses did not provide sufficient information. Therefore, it is not clear that the licensee's AFW system boundary fully meets the boundary requirements specified in GL $81-14$.

The licensee stated that the AFW system was included within the scope of seismic-related Bulletins 79-02,79-04,79-07,79-14,80-11, and IE Information Notice $80-21$. It is noted that documentation of the reanalyses of the Seiemic class I piping within the Scope of IE 79-14 was being completed, and the final reports were scheduled to be prepared by November 1991 .

\subsection{WALKDOWN OF NONSE ISMICALLY-QUALIFIED PORTION OF THE AFW SYSTEM}

A walkdown is not required because no lack of seismic qualification of the AFW system is indicated.

\subsection{ADDITIONAL INFORMATION}

The licensee provided a schematic sketch of the AFW system including the water source, heat sink, sunction and discharge piping, major mechanical equipment, and structures housing and supporting the AFW system items.

\section{CONCLUSIONS}

The licensee's responses provided all the information that was explicitly requested by GL $81-14$. Based on the information, we conclude that the $A F W$ systems at Surry Nuclear Plant, Units 1 and 2, will be able to provide the safety-related function following a SSE to assure safe shutdown of the plant. Therefore, we recommend that no further action be initiated regarding upgrading of the AFW systems of these plants under NRC Multiplant Action C-14. 


\section{REFERENCES}

1. D. G. Eisenhut, "Multiplant Action Plan G-14; Seismic qualitication of Auxiliary Feedwater System," U. S. Nuclear Regulatory Commission, memorandum to H. R. Denton (February 20, 1981).

2. U. S. Nuclear Regulatory Comission, Generic Letter to all operating pressurized water reactor licensee,, "Seismic qualification of Auxiliary Feedwater Sy6tem," (February 10, 1981).

3. R. H. Leasburg, Virginia Electric and Power Company (VEPCo) letter to H. R. Denton of U. S. Thelear Regulatory Commission, "Seismic Qualification of Auxiliary Feedwater Systems, Surry Power Station Units 1 and $2, "$ July 16, 1981.

4. S. Varga, U. S. Nuclear Regulatory Commission letter to R. H. Leasburg, VEPCO, "kequest for Additional Information on Seismic Qualification of the Auxiliary Feedwater System, Surry Nuclear Plant Units 1 and 2," January 6,1982 .

5. R. H. Leasburg, Virginia Electric and Power Company, letter to H. R. Denton of U. S. Nuclear Regulatory Commission, "Auxiliary Feedwater System Seismic Qualification, Surry Power Station Units 1 and 2," February 12, 1982. 


\section{SEISMIC QUALIFICATION OF AUXILIARY FEEDWATER SYSTEM TECHNICAL EVALUATION REPORT}

THREE MILE ISLAND NUCLEAR STATION, UNIT 1

\section{INTRODUCTION}

Since the accident at Three Mile Island, considerable attention has been focused on the capability of niclear power plants to reliably remove decay heat. The NRC has recently undertaken Multiplant Action Plan C-14 "Seisnic Qualification of AFW Systems,"I which is the subject of this evaluation.

To implement the first phase of Action Plan C-14, the NRC issued Generic Letter No. 81-14 "Seismic Qualification of AFW Systems,"2 dated February 10, 1981, to all operating PWR licensees. This letter requested each licensee (1) to conduct a walkdown of nonseismically qualified portions of the AFW system and identify deficiencies amenable to simple actions to improve seismic resistance, and (2) to provide design information regarding the seismic capability of the AFW system to facilitate NRC backfit decisions.

The licensee of Three Mile Island Nuclear Station, Unit 1, responded with letters dated September 29 and December 8,1981 , and February 16, $1982.3-5$ The licensee's responses were found not to be complete and a Request for Additional Information (RAI) was issued by the NRC, dated April 5, 1982.6 The licensee provided supplemental responses in letters dated July 7 , September 14, and September 29, and December 20, 1982.7-10 The information in Ref. 10 substantially altered the concluaion from our evaiuation of the information provided in Refs. 3 to 5 and 7 to 9 . For this reason, a meeting was held between the NRC staff and licensee on January 7, 1983, in order to clarify certain issues on the seismic capability and operating procedures of the AFW system at this plant. 11 The 1 icensee responded with additional letters dated February 4, March 22, and May 2, 1983.12-14

This report is a technical evaluation based on the information from the licensee's responses to the Generic Letter, and includes a recomendation regarding the need for additional analysis and/or upgrading modifications of this plant's AFW system.

\section{EVALUATION}

Information provided in the licensee's response include:

- Specification of the overall seismic capability of the AFW system.

- Identification of AFW system components that are currently nonseismically qualified for SSE.

- Description or procedure for switchover to a seismically qualified secondary water source.

- Discussion of levels of seismic capability of nonseismically-qualified components.

- Description of the AFW system boundary.

- Status of compliance with seismic related NRC Bulletins and Information Notices. 
- Results of walkdown of nonseismically-qualified areas.

- Additionally, schematic sketch of the AFW system.

- Additionally, description of methodologies and acceptance criteria for seismically qualified components.

Wc have reviewed the licensee's responses, and a point-by-point evaluation of the 1 icensee's responses against the Generic Letter's requirements as shown below.

\subsection{SE ISMIC GAPABILITY OF THE AFW SYSTEM}

Except for those items identified in the following, the AFW system has been designed, constructed, and maintained to withstand a SSE utilizing methods and acceptance criteria consistent with that applicable to other safety-related systems in the plant. Presently, those items identified by the licensee as not being fully seimmically qualified are evaluated below.

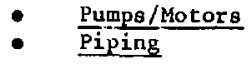

None

(a) The portion of the recirculation lines for the emergency feedwater pumpe, between the manual isolation valves (EFV-20 A/B and $\mathrm{EFV}-22$ ) and the condensate storage tank (CST) "B", were net seismically designed. However, we believe that according to the licensee's atatement a failure of inese lines would cause only an inplant spill and not a loss of safety function. In addition, the licensee indicated that these lines will be upgraded to seismic class I at the next refueling outage. (b) The condenser hotwell supply lines are nonseismic Class $I$. However, we believe that according to the licensee's statement a postulated break of these lines does not cause a safety concern, because the plant. operating procedures will be revised to assure the closure of isolation valves between the hotwell and the A.F suction line $(\mathrm{CO}-\mathrm{V}-14 \mathrm{~A} / \mathrm{B})$ and the values on the cross-tie line between the two $\operatorname{csTs}(\mathrm{CO}-\mathrm{V}-111 \mathrm{~A} / \mathrm{B})$; hence, the condenser hotwell supply lines will be isolated when the water level of either CST reaches the technical specification limit during the interim period before the long-term modifications are completed. (c) Based on the submitted sketches, not all connected branch lines from the AFW system are oeismic Class I beyond the first valve and up to a point of three 
- Valves/Actuators

- Power Supplies orthogonal restraints. However, we believe, that according to the licensee's walkdwon of these branch lines, they are seismically adequate. (d) The instrument air-supply line from valve (IA-v27) to the AFW aystem is not seismically qualified. However, the licensee indicated that seismically-qualified check valves are provided to maintain the integrity of the Class I two-hour air backup supply (bottled) for (EFW $30 \mathrm{~A} / \mathrm{B})$, (EFV $8 \mathrm{~A} / \mathrm{B} / \mathrm{C})$, (MSV 6), and (4 A/B). Based on the given information above, we judge that the AFW system piping presently possesses an SSE level of seismic capability. All valves were designed such that the OBE stresses would be below yield and SSE stresses would be within ultimate strength. The valve functional operability during and after a SSE has been assured based on calculations. Based on the given information, we judge that the valves/actuators presently have a seismic capacity equivalent to the SSE level.

Portions of the power supplies have been identified by the licensee as nonseismic class $I$ in a recent evaluation. They include: (a) Power supplies for auxiliary steam to the EF turbine pump and motor operators for the condensate storage tanks (CST) $A / B$. Isolation valves (CO-V-10 A/B) were not designed to seismic requirements; however, the licensee indicated that they are not part of the emergency power supply system and, therefore, are nonessential items. (b) The power supply from the motor operated valves $(\mathrm{CO}-\mathrm{V}-111 \mathrm{~A} / \mathrm{B})$ in the cross tie between the condensate storage tanks A/B will be changed from the existing nonvital power sources to Class lE vital power sources. (c) Cable routing for the power supply to motor operated valves (CO-V-14 A/B) between the hotwell and the AFW suction line will be upgraded to meet seismic Class I requirement. Upgrading modifications to items (t) and (c) have been proposed by the licensee, and are planned to be 
Water Source (s)

Initiation/Control Systems implemented before the startup from the next (Cycle No. 6) refueling. Also, we believe that according to the licensee's statement, a failure of the power supplies noted in (b) and (c), will not prevent the AFW system from initally performing its safety function and adequate time exists for manual action to be taken to preserve minimum CST inventory. Based on the given information above, we conclude that the present level of seismic capability of the power supplies to be equivalent to the SSE. None

Firstly, items identified by the licensee as nonseismically qualified, but judged by us as nonessential, include: (a) Cable routing of motor operators for the main steam supply isolation valves to the turbinedriven pump (MS-V2 A/B) and the main steam bypass to the condensate valves (MS-VB A/B); (b) Solenoid valves and limit switch that control the valves (MS-V123 A/B) to provide main steam to the turbine; (c) Cable routing of motor op'rators for the main stesm isolation valves (MS-VI A/B/C/D); (d) Cable routing of motor operators of the main steam to the EF turbine-pump valves (MS-V10 A/B); (e) Local startex for the (MS-V10 A/B) motor operators; (f) Limit switch on the EF turbine-pump steam-supply regulating valve; and ( $g$ ) Flow switches and control circuitry of recirculation flow-control valves (EF-V8 $\mathrm{A} / \mathrm{B} / / \mathrm{C}$ ). Items (a) to (f) are judged nonessential based on the licensee's statement that the AFW system safety function can be achieved with the electric pumps and without relying on the turbine-driven pump, and Item $(g)$ is judged nonessential because of the licensee's cormitment to lock "open" the recirculation line valve, (EF-V8 A/B/C). Secondly, those nonseismically-qualified items with modifications to be completed by the first refueling after the restart include: ( $h$ ) Converter (EP-V-5A) for control valve (EF-V-30A); and (i) Low 
- $\quad$ Structures
The turbine building is $\mathrm{Class}_{\mathrm{A}} \mathrm{I}$, and with some atiffening it could withstand an OBE. However, we believe that, according to the licensee's statement, those AFW power supplies and initation/control systems routed thorugh this building could fail without imparing the safety function of the AFW system. We, therefore, judge that the turbine building is nonessential and, hence, all structurs supporting or housing the AFW components possess as SSE level of sf imic capability.

Based on our evaluation described above, those areas of the AFW system judged not to possess a SSE seismic capability are identified below.

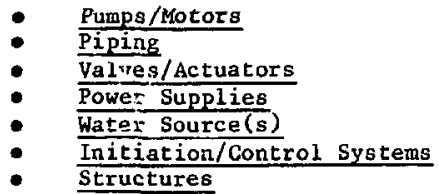

None

None

None

None

None

None*

None

In summary, our evaluation indicated that the licensee's AFW system will possess an SSE level of overall seismic capability when their planned modifications are completed at the next refueling outage.

The primary-water source is the condensate storage tank. This tank and the suction piping to the AFW pumps are seismic Class I. However, in two cases, there is only a single isolation valve (CO-V-14) between the seismic Class I water-supply piping and the nonseismic Class I piping to the condenser hotwe1l. In either case, failure of that valve to isolate the condensate storage tank from the nonseismic class I piping could result in that particular condensate storage tank draining to the condenser hotwell or turbine building. The licensee had therefore conducted an evaluation of the condensate system and identified some necessary modifications and changes of operating procedures, as discussed earlier, that will be implemented prior to startup from the next (Cycle No. 6) refueling. Modifications recomended by the licensee include: (a) Power supply modifications that have been mentioned ander the power supplies evaluation. (b) Plant operating procedures for AFW system would be changed to provide guidance to the operator to isolate the CST from the AFW system by closing valves (CO-V-III A/B) and (CC-V-14 A/B) from the control room whenever the CST reaches the technical specification limit following AFW system initiation. Additionally, the licenses stated that a secondary water supply of river water is available from the reactor building emergency cooling pumps and it is entirely seismic class I. This water supply enters the AFW pump common-sunction header between two sectionalizing valves $(E F-V-1$ A/B). Manual actions are required to access this backup water supply. Two series motor-operated valves (EF-V-4\&5) to the river water system are normally locked "closed" and the motor control-center breakers

‡ Will be fully qualified when the licensee's planned upgrade/moditications are completed at the next refueling outage. 
for these valves are locked "open". If the backup supply of river water to the AFW system is needed, these locks will be removed and the breakers "closed." The switchover procedure to use the backup water sources is still under review by the licensee.

Seismic qualification information for any alternate decay-heat removal system was requested by the GL $81-14$, if substantial lack of seismic qualification of the AFW system is indicated. We believe such information for any alternate decay-heat removal system is not required, because the AFW system will possess an SSE level capability by the next refueling outage.

Regarding the AFW system boundary, the schematic sketches provided by the licensee show that there are branch lines without a second isolation valve, which is normally "closed" or capable of automatic closure. However, we believe that according to the licensee's statement, 14 the lack of the double valve isolation is acceptable. We, therefore, concluded that the AFw system boundary does not fully conform to the definitions of GL B1-14, but the deviation is nonessential.

The AFW system was included within the scope of IE Bulletin 79-02, 79-04, 79-07, 79-14, 80-11 and IE Information Notice 80-21.

\subsection{WALKDOWN OF NONSEISMICALLY-QUALIFIED PURTION OF THE AFW SYSTEM}

Walkdown has been performed in conjunction with IE Bulletins 79-02 and 79-14. The licensee identified $\mathrm{ix}$ deficiencies that have been corrected: (a) Support EF-8, repair completed on 4/7/81, (b) Support EF-72, repair completed on $7 / 27 / 81$, (c) Support EF-125, repair completed on $7 / 31 / 81$, (d) Conduit to MSV-6 has loose clamp that needs to be tightened, (e) Conduit to EFW $8 \mathrm{~B}$ had no clamps to hold it to existing steel and needs clamp for security, (f) Unistrut supporting conduit to $(E F-V-8 C)$ is loose at the base and needs to be tightened. The licensee stated that items (d) to (f) have been or will be completed prior to restart.

\subsection{ADDITIONAL INEORMATION}

The licensee provided schematic sketches of the AFW system including the water sources, heat sink, suction and discharge piping, major mechanical equipment, and structures supporting and housing the AFW system items.

Additior 11 ly, licensee's responses provided a description of the methodologies, loading combinations and acceptance criteria that were used in the design of the seismically qualified portions of the AFW system, by referring to the appropriate sections of the FSAR.

\section{CONCLUSIONS}

The information contained in licensee's responses to the GL $81-14$ is complete. The licensee conducted a partial walkdown of the nonseismicallyqualified areas of the AFW system. The valve arrangement in the AFW system branch lines does not fully conform to the boundary definitions opecified in GL 81-14, but we judge the deviation acceptable. 
Based on submitted information, we conclude that presently the AFW system will possegs an SSE level of seismic capability when the scheduled modifications are completed by the Cycle No. 6 refueling outage. Therefore, we recommend that no further action be initiated regarding upgrading of the AFW system of this plant under the NRC Multiplant Action Plan C-14.

\section{REFERENCES}

1. D. G. Eisenhut, U. S. Nuclear Regulatory Commission, memorandum to H. R. Denton, "Multiplant Action Plan C-14; Seismic Qualification of Auxiliary Feedwater Systems," (February 20, 1981).

2. U. S. Nuclear Regulatory Commission, Generic Letter No. 81-14 to all operating pressurized-water reactor licensees, "Seismic Qualification of Auxiliary Feedwater Systems;" (February 10, 1981).

3. H. D. Hukill, Metropolitan Edison Company, letter to D. G. Eisenhut of

U. S. Nuclear Regulatory Commission, September 29, 1931 .

4. H. D. Hukill, Metropolitan Edison Company, letter to D. G. Eisenhut of

U. S. Nuclear Regulatory Commission, December 8, 1981.

5. H. D. Hukill, Metropolitan Edison Company, letter to D. G. Eisenhut of U. S. Nuclear Regulatory Commission, "LFW Seismic Qualification Electrical," February 16, 1982.

6. U. S. Nuclear Regulatory Commission, Letter to Metropolitan Edison Company, "Request for Additional Information on Seismic Qualification of the Auxiliary Feedwater System, Three Mile Island Nuclear Station, Unit 1," April 5, 1982.

7. H. D. Hukill, Metropolitan Edison Company, letter to J. F. Stolz of U. S. Nuclear Regulatory Commission, July 7, 1982.

8. H. D. Hukill, General Public Utility Nuclear Corporation, letter to J. F. Stolz of U. S, Nuclear Regulatory Comission, September 14, 1982.

9. H. D. Hukill, General Public Utility Nuclear Corporation, letter to J. F. Stolz of U. S. Nuclear Regulatory Commission, September 29, 1982.

10. H. D. Hukill, General Public Utility Nuclear Corporation, letter to J. F. Stolz of the U. S. Regulatory Commission, December 20, 1982.

11. Minutes of Meeting between U. S. Nuclear Regulatory Commission and General Public Utility Nuclear Corporation on Jaluary 7; 1983.

12. H. D. Hukill, General Public Utiltiy Nuclear Corporation, letter to J. F. Stolzof the the U. S. Nuclear Regulatory Commission, February 4, 1983.

13. H. D. Hukill, General Public Utility Nuclear Corooration, letcer co J. F. Stola of the U. S. Nuclear Regulatory Commisssion, March 22, 1983.

14. H. ע. Hukill, General Public Utility Nuclear Corporation, letter to J. F. Stolz of the U. S. Nuclear Regulatory Commission, May 2, 1983. 


\section{SEISMIC QUALIFICATION OF AUXILIARY FEEDWATER SYSTEM TECHNICAL EVALUATION REPORT}

TURKEY POINT NUCLEAR PLANT, UNITS 3 AND 4

\section{INTRODUCTION}

Since the accident at Three Mile Island, considerable attention has been focused on the capability of nuclear power plants to reliably remove decay heat. The NRC has recently undertaken Multiplant Action Plan C-14 "Seigmic Qualification of AFW Systems,"l which is the subject of this evaluation.

To implement the first phase of Action Plan C-14, the NRC issued Generic Letcer No. 81-14 "Seismic Qualification of AFW Systems," 2 dated February 10, 1981, to all operating PWK licensees. This letter requested each licensee (1) to conduct a walkdown of nonseismically qualified portions of the AFW system and identify deficiencies amenable to simple actions to improve seismic resistance, and (2) to provide design information regarding the seismic capability of the AFW system to facilitate NRC backfit decisions.

The licensee of Turkey Point Nuclear Plant, Unita 3 and 4, responded with a letter dated September $8,1981.3$ The licensee's response was found not to be complete and a Request for Additional Information (RAI) was issued by the NRC dated April 9, 1982.4 The licensee provided a supplemental response in a letter dated May 25, 1982.5

This report is a technical evaluation based on the information from the icensee's responses to GL $81-14$, including recommendations for additional analysis and/or upgrading modification of tisis plant's AfW system.

\section{EVALUATION}

Infurmation provided in the licensee's response include:

- Specification of the overall seismic capability of the AFW system.

- Identification of AFW system components that are currently nonseismically qualified for SSE.

- Discussion of levels of seismic capability of nonseismically-qualified components.

- Description of the AFH system boundary.

- Status of compliance with seismic related NRC Bulletins and Information Notices.

- Additionally, schematic sketch of the AFW system.

- Additionally, description of methodologies and acceptance criceria for seismically qualified components.

- Additionally, modification associated with installation of new turbines along with schedules for such modifications. 
We have reviewed the licensee's responses, and a point-by-point evaluation of the 1 icensee's responses against the Generic Let ter's requirements as shown below.

\subsection{SEISMIC CAPABILITY OF THE AFW SYSTEM}

Except for those items identified in the following, the AFW system has becn designed, constructed, and maintained to withatand a SSE utilizing methods and acceptance criteria consistent with that applicable to other safety-related systems in the plant. Presently, those items identified by the licensee as not being fully seismically qualified are evaluated below.

\section{- Pumps/Motors}

- Piping

- Valves/Actuators

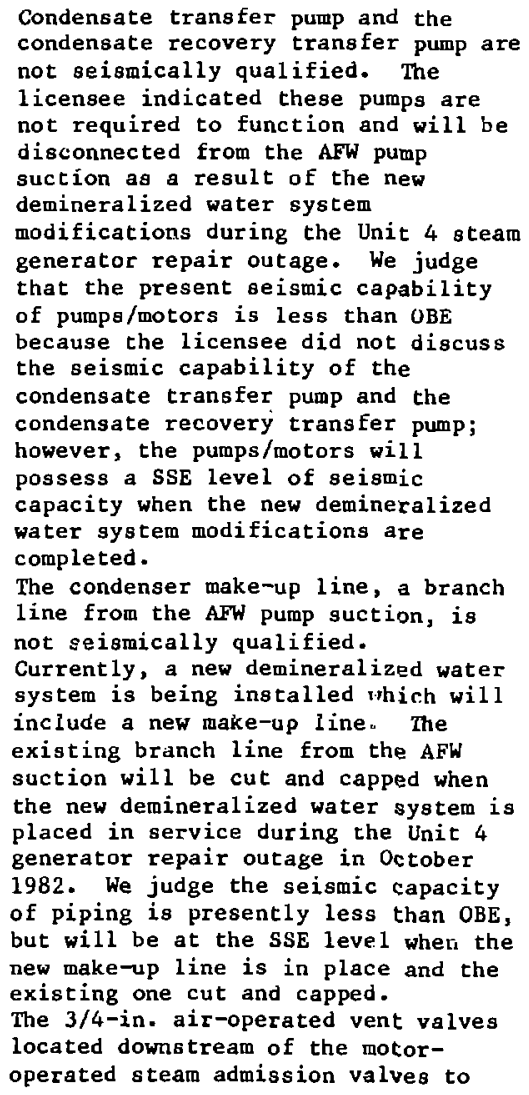

Condensate transfer pump and the condensate recovery transfer pump are not seismically qualified. The licensee indicated these pumps are not required to function and will be disconnected from the AFW pump suction as a result of the new demineralized water system modifications during the Unit 4 steam generator repair outage. We judge that the present seismic capability of pumps/motors is less than OBE because the licensee did not discuss the seismic capability of the condensate transfer pump and the condensate recovery transfer pump; however, the pumps/motors will possess a SSE level of seismic capacity when the new demineralized water system modifications are completed. The condenser make-up line, a branch line from the AFW pump suction, is not seismically qualified. Currently, a new demineralized water system is being installed which will include a new make-up line. The existing branch line from the AFW suction will be cut and capped when the new demineralized water system is placed in service during the Unit 4 generator repair outage in October 1982. We judge the seismic capacity of piping is presently less than OBE, but will be at the SSE level when the new make-up line is in place and the existing one cut and capped. The 3/4-in. air-operated vent valves located downstream of the motoroperated steam admission valves to 
Power Supplies

- Wate. Source(s)

- Initiation/Control Systems the AFW turbines are provided to prevent the AFW curbines from turning due to valve leakage. Failure of these valves in the open position will affect these valves in performing the required function. However, the licensee stated that the inability of these valves to perform their required function will not prevent the $A F W$ gystem from performing its safety function. Therefore, we conclude that the present level of seismic capability of the valves/actuators is equivalent to the SSE.

The power supplies for the flow indication and flow control for Unit 4 are not seismically qualified. The licengee stated that modifications are planned to be performed in Unit 4 during the next scheduled outage of sufficient duration. We judge that the seismic capability of the power supplies in Unit 4 is presently less than OBE, but will be upgraded to SSE level upon completion of modifications. The licensee stated that the primary water source and path includes a nonseismically-qualified condensate recovery tank, which supports the condensate recovery pump acting as a seismic pipe anchor. The condensate recovery line will be disconnected from the ATW pump suction as a result of the new demineralized water system modifications. Regarding the installation of the new demineralized water system, the DWDS storage tank is complete. The tie-ins to Unit 3 were completed prior to its start up from its steam generator repair outage. The tie-ins to Unit 4 will be completed during the Unit 4 steam generator repair outage starting in October 1982. We conclude that the entire primary water source and path will possess a SSE level seismic capacity when the licensee completes the new demineralized water gystem. Norseismically qualified areas are discussed as follows. (a) The condensate atorage tank level 
transuitter was procured to control grade. The licensee stated that loss of function of the transmitter and indicator will not prevent the AFW system from performing its function. In addition, redundant safety grade indication is being added. (b) Local pressure indicators were procured to control grade. The licensee. stated that loss of the pressure indicator function will not prevent the AFW system from performing its required function. (c) Pressure switches located upstream of the AFW turbine trip and throttle valves are currently used to initiate the air supply to the normally closed turbine pressure reducing valve. However, the need for these pressure switches with the new high pressure AFW turbines has yet to be determined by the licensee since the normally closed turbine pressure reducing valves will be replaced by normally open trip and

Based on our evaluation described above, those areas of the AFW system judged not to possess a SSE seismic capability are identified below.

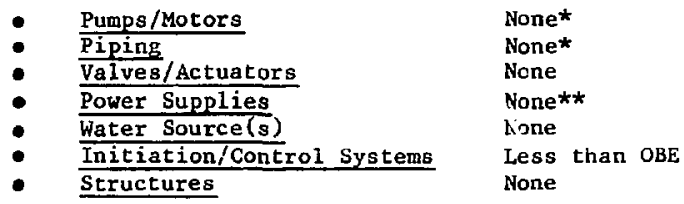

In sumbary, our evaluation indicated that the licensee's AFW system does not possess an overall seismic capability that can withstand a SSE.

The primary water source and supply path is currently not seismically qualified but will possos a SSE capacity when the licensee completes the new demineralized water system modifications. Therefore, information on switchover to a seismically qualified secondary water source and supply path is not involved.

't Presently less than $O B E$, and will be fully qualified when licensee's proposed upgrade/modification is completed.

** Presently less than OPE for Unit 4, and will be fully qualified when licensee's proposed upgrade/modification is completed. 
Seismic qualification information for any alternate decay neat removal system was not pruvided in the licensee's responses. This information was requested by GL $81-1 \%$ if substantial lack of seismic qualification is indicated for the AFW system. Based on the information provided by the licensee we did not find that the license's AFW system has a SSE capability. However, we judge that information on an alternate decay heat removal system seismically qualified to the SSE level and appropriate operating procedures are not needed if the licensee is required to reanalyze and/or modify the existing AFW system to a SSE capacity.

\section{CONCLUSIONS}

The information contained in licensee's responses to GL $81-14$ is complete except that regarding the present level of seismic capability of some areas of the initiation/control systems. The walkdown conducted by the licensee identified some deficiencies and corrective actions were planned with completion dates provided. The licensee has stated that the AFW system wil! be upgraded during the Unit 4 steam generator repair outage commencing in October 1982. However, no plan is given of modification of the nonseismically-qualified portion in the initiation/control systems. The licensee has also stated that the AFW system boundary extends to only the first normally closed valves on branch lines and therefore it does not fully conform to the definition specified in the GL 81-14.

Eased on the submitted information, we conclude that the AFW system does not provide a reasonable assurance to perform its required safety function following a SSE because presently portions of the initiation/control systems do not have a SSE seismic capabity and the AEW system boundary does not conform to GL 81-14's requirements. In conclusion, we recommend that the NRC considers reouiring the licensee (a) to provide a reanalysis and/or modification to acquire a SSE capacity for the initiation/control systems, and (b) to evaluate and/or correct the AFW system boundary deviation to assure the required safety function.

\section{REEERENCES}

1. D. G. Eisenhut, "Multiplant Action Plan C-14; Seismic Qualification of Auxiliary Feedwater System," U. S. Nuclear kegulatory Commission, memorandum to H. R. Denton (February 20, 1981).

2. U. S. Nuclear Regulatory Commission, Generic Letter to all operating pressurized water reactor licensees, "Seismic Qualification of Auxiliary Feedwater System," (February 10, 1981). 


\section{SE ISMIC QUALIFICATION OF AUXILIARY FEEDWATER SYSTEM \\ TECHNICAL EVALUATION REPORT}

ZION STATION, UNITS 1 AND 2

\section{INTRODUCTION}

Since the accident at Three Mile Island, considerable attention has been focused on the capability of nuclear power plants to reliably remove decay heat. The NRC has recently undertaken Multiplant Action Plan C-14 "Seismic Qualification of AFW Systems,"

To implement the first phase of Action Plan C-14, the NRC issued Generic Letter No. 81-14 "Seismic Qualification of AFW Systems,"2 dated February 10, 1981; co all operating PWK licensees. This letter requested each licensee (1) to couduct a walkdown of nonseismically qualified portions of the AFW system and identify deficiencies amenable to simple actions to improve seismic resistance, and (2) to provide design information regarding the seismic capability of the AFW system to facilitate NRC backfit decisions.

The licensee of Zion Station, Units 1 and 2, responded with a letter dated July 14, 1981.3 The licensee's response was found not to be complete and a Request for Additional Information (RAI) was issued by the NRC, dated January 6, 1982.4 The licensee provided a supplemental response in a letter dated July $12,1982.5$

This report is a technical evaluation based on the information from the licensee's responses to $\mathrm{GL} 81-14$, including recomendations for additional analysis and/or upgrading modification of this plant's AFW system.

\section{EVALUATION}

Information provided in the licensee's response include:

- Specification of the overall seismic capability of the AFW system.

- Identification of currently nonseismically-qualified components or the AFW system.

- Description of procedure for switchover to a seismically qualified secondary water source.

- Status of compliance with seismic related NRC Bulletins and Information Notices.

- Additionally, isometric drawings of the AFW system piping and a diagram of the steam generator feedwater piping.

- Additionally, description of methodologies and acceptance criteria for the design of seismically qualified components.

We have reviewed the licensee's responses, and a point-by-point evaluation of the licensee's responses against the Generic Letter's requirements as shown below. 
Except for those items identified in the following, the AFW system has been designed, constructed, and maintained to withstand a SSE utilizing methods and acceptance criteria consistent with that applicable to other safety-related systems in the plant. Presently, those items identified by the I icensee as not being fully seismically qualified are evaluated below.

\section{- Purps/Motors}

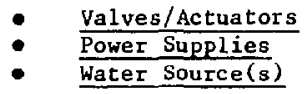

- Initiation/Control Systems

- Structures

\section{None}

The system piping from tre condensate storage tank to a motorized valve at suction of the AFW pumps. However, the licensee indicated in their responses that a seismically qualified secondary water source (the service water system) and supply path exists in the plant. Therefore, we judge that the AFW system pipings in Zion Station Units $I$ and 2 possess an overall seismic capability that will withstand the SSE.

None

None

The primary water source, $i \cdot e \cdot$, the condensate scorage tank, is not seismically qualified. However, a secondary water and supply path exists and it is designed as seigmic Class 1. A procedure is available for switching frow the primary to the secondary water source. Therefore, we conclude that the water sourct: possess a SSE level of seismic capability. None None

Based on our evaluation described above, those areas of the AFW Bystem judged not to possess a SSE seismic capabilicy are identified below.

\begin{tabular}{|c|c|}
\hline Pumps/Motors & \\
\hline Piping & \\
\hline Valves/Actuators & \\
\hline Power Supplies & \\
\hline Water Source (8) & \\
\hline Initiation/Controi & Systems \\
\hline Structures & \\
\hline
\end{tabular}

In summary, our evaluation indicated that the AWW system at zion station Units 1 and 2 possesses a SSE level of oeismic capability.

The primary water source and supply path is not seismically qualified and, therefore, switchover to the seimically qualified secondary water source 
and supply path is required. A switchover procedure in Zion Station Units 1 and 2 is available and is maintained on file at the plant as part of zion Station's abnormal operating procedure program. The procedure is based on the condensate storage tank level and consists of two sections. The first section describes the procedure for a slow, steady loss of condensate storage tank level, and the second section describes the procedure for a sudden, uncontrolled lose of condensate storage tank level.

Information regarding the seismic capability of any alternate decay heat removal system is not required because the AFW system has a sse level of seismic capability.

kegarding the AFW system boundary, the licensee's responses did not provide sufficient information. It is not clear whether the licensee's AFW system boundary fully meets the boundary requirement; specified in GL $81-14$.

The licensee stated that the AFW system was included within the scope of seismic related Bulletins 79-02, 79-04,79-07, 79-14, 80-11 and IE Information Notice $80-21$.

\subsection{WALKDOWN OF NONSE ISMICALLY-QUALIFIED PORTION OF THE AFW SYSTEM}

The licensee conducted a walkdown of the nonseismically-qualified portion of the AFW system, i.e., the primary water supply path. The licensee stated that the results of the walkdown indicated that the nonseismically-qualified primary water supply $l$ ine $i s$ adequately designed and installed in accordance with the original plant requirement. In addition, station personnel will conduct a general maintenance program for all hangers on the primary water supply path, by tightening or replacing bolts, tightening turn buckles, and adjusting pipe attachments.

\subsection{ADJIT IUNAL INFORMATION}

The licensee provided six isometric drawings of the AFW sysuem piping and a diagrata of the steam generator feedwater piping. Additionally, licensee's responses provided a description of the methodologies and acceptance criteria for the design of the seismically qualified components.

\section{CONCLUSIONS}

The information contained in licensee's responses to the GL 81-14 is complete except that it did not clarify whether the AFW system boundary fully conforms to the definitions of the GL 81-14.

Based on the submitted information, we conclude that the AFW system is fully seismically qualified and is able to provide the safety related function following a SSE assuming that the AFW sys:em boundary fully conforms to the boundary definitions specified in the GL 81-14. Therefore, we recomend that no further action be initiated regarding reanalysis and/or modification of the AFW system of this plant under NRC Multiplant Action Plan C-14. 


\section{REFERENCES}

1. D. G. Eisenhut, "Multiplant Action Plan C-14; Seismic Qualification of Auxiliary Feedwater System," U. S. Nuclear Regulatory Comission, memorandum to H. R. Denton (February 20, 1981).

2. U. S. Nuclear Regulatory Commission, Generic Letter to all operating pressurized water reactor licensees, "Seismic Qualification of Auxiliary Feedwater System," (February 10, 1981).

3. T. R. Tramm, Commonwealth Edison, letter to H. R. Denton of U. S. Nuclear Regulatory Commission, July 14, 1981.

4. S. A. Varga, USNRC, letter to L. 0. DelGeorge of Commonwealth Edison, "Request for Additional Information on Seismic Qualification of the Auxiliary Feedwater System, Zion Station, Units 1 and 2," January 6, 1982.

5. F. G. Lentine, Commonwealth Edison, letter to H. R. Denton of USNRC, July 12,1982 . 